\title{
Çanakkale Muharebelerinde İngiliz Askeri İstihbarat Raporları*
}

\author{
Mehmet Kıbıl*
}

(ORCID ID: 0000-0002-4529-5215)

Makale Gönderim Tarihi

10.12.2019
Makale Kabul Tarihi

30.01 .2020

\section{Özet}

Tarihte bilinen en eski istihbarat birimlerinden olan İngiliz Gizli Servisi, I. Dünya Savaşı yıllarında Osmanlı topraklarında yoğun şekilde istihbarat faaliyetlerinde bulunmuş ve savaş boyunca askeri, siyasi, ekonomik ve coğrafi bilgiler elde ederek bunları raporlar halinde ilgili makamlara sunmuştur.

Çanakkale Muharebeleri başlamadan önce ve muharebeler devam ederken İngiliz Askeri İstihbaratı, Türk ordusunun genel durumu, birliklerin pozisyonları, bu birliklerin nitelikleri ve nicelikleri ve Gelibolu Yarımadası'nın coğrafi özellikleri gibi pek çok konuyla ilgili çok sayıda detaylı rapor hazırlamıştır. Bu askeri istihbarat raporlarının içeriği sadece Çanakkale Muharebeleri ile sınırlı kalmamış, Osmanlı Devleti'nin çeşitli bölgelerinde yaşanan hadiselerle ilgili bilgiler de ayrıntılarıyla verilmiştir. Özellikle başkent İstanbul'da yaşanan toplumsal, ekonomik ve siyasi gelişmeler yakından takip edilmiştir. İstihbarat bilgilerinin İstanbul, İzmir, Suriye gibi önemli merkezlerde bulunan ajanlar, buralarda yaşayan Avrupalılar ve özellikle İstanbul ve Gelibolu çevresinde yaşamış azınlıklar tarafından verildiği anlaşılmaktadır. Diğer önemli istihbarat kaynağı da Türk esir ve kaçakların ifadeleridir.

Genel olarak bakıldığında bu istihbarat raporları, kimin verdiğine göre değişmekle birlikte çeşitli yanlış bilgiler içerse de, raporların önemli bir kısmı son derece önemli ve işe yarar bilgiler vermektedir. Türkiye'de daha önce bu konuda akademik bir çalışma yapılmamıştır. Dolayısıyla, Türkiye'de tamamı ilk

\footnotetext{
* Bu makale, Yeditepe Üniversitesi II. Uluslararası Türk Kültürü ve Tarihi Sempozyumunda (01 - 02 Kasım 2018) sunulan bildirinin genişletilmesi suretiyle hazırlanmıştır.

* Doktora Öğrencisi, Yeditepe Üniversitesi, Sosyal Bilimler Enstitüsü, Tarih ABD, mehmetkibil@hotmail.com.
}

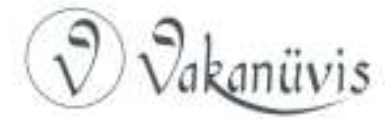


kez bu makalede yayınlanacak olan askeri istihbarat raporlarının savaşın gidişatına olan etkisi ve bu bilgilerin Türk tarafıyla karşılaştırılarak incelenmesi muharebelerin daha iyi anlaşılması açısından önem arz eder.

Anahtar Kelimeler: Çanakkale Savaşı, Askeri İstihbarat, I. Dünya Savaşı, Gelibolu, İstihbarat faaliyetleri.

\section{British Military Intelligence Reports in the Gallipoli Campaign}

\section{Abstract}

British Intelligence Service, one of the oldest intelligence service known in the history, has extensively engaged in intelligence activities in the Ottoman State during the World War I and collected military, political, economic and geographical information and reported them to the government offices.

Prior to and during the course of Gallipoli Campaign, British Military Intelligence prepared numerous detailed reports about general status of Turkish army, locations of the troops, their quantities and qualities, geographical features of the Gallipoli Peninsula. Such military intelligence reports were not only about the Gallipoli Campaign but also provided detailed information about the incidents in several regions of Ottoman Empire. It closely followed up the social, economic and political developments, especially in Istanbul, the capital. It is understood that intelligence was received from the agents in important centers such as Istanbul, Izmir, Syria, European living in such places and minorities, residing around Istanbul and Gallipoli. Another important intelligence source is the statements of Turkish prisoners and deserters.

In general terms, while such intelligence reports contained false information, depending on the intelligence source, the significant majority of the reports were considerably important and useful. There are no academic studies on this subject before in Turkey. The effect of British military intelligence reports on the course of the campaign and comparing such information with Turkish side are important for better understanding of the battles.

Keywords: Gallipoli Campaign, Military Intelligence, First World War, Gallipoli, Intelligence activities 


\section{Giriş}

I. Dünya Savaşı başlamadan kısa bir süre önce 1909 yılında kurulan İngiliz Gizli Servisi ilk resmi toplantısını 4 Ekim 1909 tarihinde Savaş Bakanlığında gerçekleştirmiştir. Oluşturulan bu Gizli İstihbarat Servisi temel işleyiş açısından ikiye ayrılmaktadır: iç istihbarat ve dış istihbarat. 1915-1916 yılları arasında ise Savaş Bakanlığı yeniden yapılandırılarak “Askeri İstihbarat Direktörlüğü" kurulmuştur. İngiliz istihbaratı ilerleyen yıllarda intiyaca göre çeşitli yapısal değişimler göstermeye devam etmiştir. İngiliz askeri istihbaratı I. Dünya Savaşı boyunca Almanya'dan A.B.D'ye, Rusya'dan Osmanlı Devleti'ne kadar oldukça geniş bir alanda faaliyet göstermiştir.

İngilizler, Çanakkale Muharebeleri başlamadan hemen önce ve muharebeler sırasında çeşitli kaynaklardan farklı türde çok sayıda istihbarat topladılar. Savaştan önce istihbarat raporları daha çok açık kaynaklara ve raporlara dayanırken, savaşın başlamasıyla bilgiler sahadaki ajanlar ve gizli gözlemler ile toplanmaya başlandı. 1914 sonuna doğru Çanakkale önlerinde askeri hareketlilik artarken İngiliz istihbaratı bölgede çalışmalarını yoğunlaştırdı. 1915 Şubat ayından itibaren ise bölgedeki Türk birlikleri ve askeri faaliyetleri hakkında önemli bilgiler toplanmaya başlandı. Bunun için Atina'da casusluk ve karşı casusluk bürosu kuruldu. Ajanlar daha çok Rumlar, Giritliler, Ermeniler, Araplar ve hoşnutsuz bazı Türklerden seçiliyordu. Seçilen adamlardan bazıları Türk hükümetine karşı isyan eden ve gerçekten İtilaf Devletleri yanlısı olanlardı. Bazılarının da Türklere karşı geçmişten gelen bazı hesapları vardı. Azınlıklardan seçilen ajanların çoğunluğu bunu para için yapmaktaydılar ve karşı tarafın daha yüksek teklif verme ve saf değiştirme intimaline karşı sürekli kontrol edilmeleri gerekiyordu. ${ }^{1}$ İse alınan bazı Anadolulu Rumlar bir insani yardım kuruluşu vasıtasıyla ajan olarak Türkiye'de çalışmaya başlamışlardı. ${ }^{2}$ Ajanlar vasıtasıyla toplanan bilgilerin çoğu Atina'da toplanıp analiz edilerek Gelibolu'da savaşan birliklere istihbarat raporları olarak yollanıyordu. Diğer yandan sadece Çanakkale ile ilgili değil, Osmanlı coğrafyasında yaşanan önemli gelişmeler hakkında da hemen her

\footnotetext{
1 John Presland, Deedes Bey-A Study of Sir Wyndham Deedes 1883-1923, London 1942, s.193.

2 Keith Jeffery, MI6-The History of the Secret Intelligence Service 1909-1919, England 2010, s.140.
}

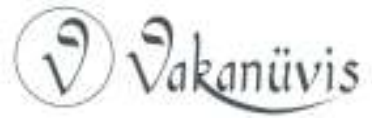


yerden casuslar vasıtasıyla oldukça geniş çapta bilginin bu raporlara girdiği görülmektedir.

Hazırlanan raporların içeriğine bakıldığında, istihbarat bilgilerini genel olarak iki başlık altında toplamak gerekir. Bu başlıklardan ilki, Osmanlı coğrafyası ve I. Dünya Savaşı'nın gidişatı hakkında neredeyse her konuda tutulan "Genel istihbarat Raporları" ve ikinci başlık olarak "Çanakkale Muharebeleri Hakkında Istihbarat Raporları"dır.

\section{Genel İstihbarat Raporları}

$\mathrm{Bu}$ raporların gerçekten çok geniş bir bilgi yelpazesini içinde barındırdığı görülmektedir. Kendi içinde de üç gruba ayırabileceğimiz bu raporların içeriği öncelikle Türk ordusunun genel durumu, niceliği ve niteliği, konuşlanmaları ve ordunun genel yapısı ile ilgilidir. İkinci olarak, Osmanlı coğrafyasında yaşanan günlük siyasi, toplumsal ve ekonomik olaylar, gelişmeler ve ihtiyaçlar yakından takip edilerek izlenmiştir. Son olarak I. Dünya Savaşı'nın genel gidişatı, diğer ülkelerin içinde bulunduğu durum üzerine çeşitli bilgilerin analiz edilerek raporlandığı görülmektedir.

\section{Genel İstihbarat Raporlarında Askeri Gelişmelerle İlgili Bilgiler}

29. Tümen'in Mayıs 1915 tarihli istihbarat raporunda "Türk Ordusunun Organizasyonu" başlığı atıldıktan sonra ayrıntılı bilgiler maddeler halinde verilmektedir. Belgenin ilk paragrafında "Osmanlı ordusu 1914 yılındaki seferberlikten kısa bir süre önce, Balkan Savaşı hadiselerinin gerektirdiği değişikliklere uygun olarak yeniden örgütlendi" dendikten sonra birliklerin sayısının azaltıldığı, redif birliklerinin kaldırıldığı ve barış zamanında alayların iki aktif bir yedek taburdan oluşturulduğu yazılmıştır. Aynı raporun devamında ise ülkenin dört ordu bölgesine ayrılarak (İstanbul-Erzincan-Bağdat-Şam) bu orduların toplam 13 Kolordu, 2 Bağımsız Tümen olmak üzere organize edildiği, kolorduların da üç veya iki tümenden oluşturulduğu belirtildikten sonra, her ordu grubunun bölgesinde olan birliklerin hangi kolordu ve tümenlerden oluştuğu sıralanmıştır. ${ }^{3}$ Türk ordu teşkilatı ile ilgili verilen bu istihbarat raporunun tamamının doğru

\footnotetext{
3 The National Archives (TNA), War Office (W.O.) 95/4305, 29 DIVISION, Headquarters Branches and Services: General Staff, 1915 July-1916 Feb., September 1915, Appendix4.
}

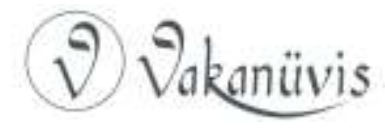


bilgilerden oluştuğu görülmektedir. Alman Islah Heyeti'nin kurulmasından sonra 14 Şubat 1913 tarihinde Teşkilat-ı Umumiye-i Askeriye Nizamnamesi yayınlanarak kara ordusu dört ordu müfettişliği, bir bağımsız kolordu ve iki bağımsız tümenden oluşturulmuştur. Yine bu raporda doğru olarak belirtildiği gibi, ordu merkezleri i̇stanbul (1. Ordu), Şam (2. Ordu), Erzincan (3. Ordu), Bağdat (4. Ordu) şehirlerinde olacak şekilde kurulmuştur. Bunların yanında Yemen'de bağımsız bir kolordu ve 21. (Asir) Tümeni ile 22. (Hicaz) tümenleri de bulunmaktadır. ${ }^{4}$ Osmanlı Devleti I. Dünya Savaşı'na bu yapılanma ile girmiştir.

Türk ordusu ile ilgili istihbarat raporları sadece ordunun organizasyonu ile kalmamıştır. Savaşın çeşitli aşamalarında birliklerin hangi bölgede oldukları, hangi tarihlerde nereden nereye kaydırıldıklarına dair son derece ayrıntılı haritalar ve krokilerle desteklenmiş ve bunlar pek çok birliğin istihbarat bültenine girmiştir. Örneğin, 1 Nisan $^{5}, 20$ Nisan $^{6}$ ve 28 Mayıs $1915^{7}$ tarihli krokilerde Türk tümenleri aktif ve yedek olarak kategorize edildikten sonra, Gelibolu'dan Suriye'ye, Erzurum'dan Irak'a kadar nerelerde konuşlandırıldıkları ayrıntılı şekilde çizilmiştir. 1 Eylül $1915^{8}$ tarihli haritada ise "Türk Kafkas Ordusu" başlığı atılarak, Doğu Anadolu'da bulunan ordunun Ruslarla olan karşılıklı hatları ve birliklerin hangi bölgede oldukları belirtilmiştir. Bütün bu harita ve krokilerin yanında, Türk birliklerinin nereden nereye hangi tarihlerde kaydırıldıkları da raporlara günü gününe geçirilmiştir.

16-17 Mayıs 1915 tarihli istihbarat raporunda ise 30 Nisan $1915^{\prime}$ te İstanbul'dan Afyon'a bir tümenin yola çıktığı, 3 Mayıs 1915'te Şam'dan bir trenin kuzeye doğru hareket ettiği ve muhtemelen içindeki birlikleri İstanbul veya Çanakkale'ye götürdüğü bilgisi yer almaktadır. Yine 14

\footnotetext{
${ }^{4}$ Türk Silahlı Kuvvetleri Tarihi (1908-1920), C.III, Kısım: 6, Kitap: 1, Ankara 1971, s. 199.

5 TNA, W.O. 95/4304, 29 DIVISION, Headquarters Branches and Services: General Staff, 1915 Jan.-June, April 1915, Appendix-5.

${ }^{6}$ TNA, W.O. 95/4304, 29 DIVISION, Headquarters Branches and Services: General Staff, 1915 Jan.-June, April 1915, Appendix-9.

7 TNA, W.O. 95/4304, 29 DIVISION, Headquarters Branches and Services: General Staff, 1915 Jan.-June, May 1915, Appendix-34.

8 TNA, W.O. 95/4305, 29 DIVISION, Headquarters Branches and Services: General Staff, 1915 July-1916 Feb., September 1915, Appendix-6.
}

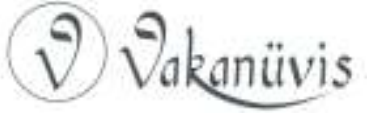


Mayıs tarihinde altı ulaşım aracından oluşan konvoyun İstanbul'dan Çanakkale'ye doğru hareket ettiği ve bu konvoyun içinde 1. Kolorduya ait tümenlerin muhtelif alaylarının olduğu belirtilmektedir. ${ }^{9}$

Akdeniz Seferi Kuvvetleri genel karargâhının, 6 Ağustos'ta Anafartalar'a çıkarma yapacak olan 9. Kolordu'ya gönderdiği 24 Temmuz 1915 tarihli raporda da Suriye bölgesindeki Türk birlikleri ve savunma hatları hakkında 240, İzmir bölgesindeki Türk birlikleri hakkında ise 40 sayfa istihbarat raporunun gönderildiği görülmektedir. ${ }^{10} \mathrm{Bu}$ raporlar, Suriye ve İzmir'deki Türk savunması hakkında oldukça ayrıntılı bilgiler içermektedir.

\section{İstihbarat Raporlarında Sosyal ve Ekonomik Gelişmelerle ilgili Veriler}

Osmanlı coğrafyasında yaşanan günlük siyasi, toplumsal ve ekonomik gelişmeler de istihbarat raporlarının içeriğinde önemli yer kaplamaktadır. Bu konular hakkında oldukça enteresan ve geniş bilgiler toplanmıştır.

29. Tümen'e ait 26 Mayıs 1915 tarihli altı sayfalık son derece ayrıntılı istihbarat bülteninin son üç sayfası, Türkiye'de savaş döneminde şiddetle ihtiyaç duyulan çeşitli malzemeler ve bu malzemelerin temini hakkındaki bilgileri içermektedir. "Türk ihtiyaçları" başlığının altında; "Raporlardan açıkça görülüyor ki, İstanbul'daki Türkler, deniz ticaretinin sona ermesiyle ortaya çıkan arz sıkıntısının giderek artacağını düşünüyor. İstanbul tedariklerinin çoğunu Marmara'dan aldığı için, denizaltı tehdidi nedeniyle fiyatlar ciddi bir şekilde arttı" notu düşüldükten sonra, başlıklar halinde temel ihtiyaçların temini hakkında bilgiler verilmektedir. Bu raporda Anadolu'daki tek önemli kömür madenin Zonguldak'ta olduğu ve burada etkili olan Rus donanması sebebiyle her 2-3 günde bir kömür taşıyan gemi batırıldığı belirtildikten sonra, ülkede tahılın bol miktarda olduğu ve iyi hasat yapıldığına değinilmiştir.

\footnotetext{
9 TNA, W.O. 95/4304, 29 DIVISION, Headquarters Branches and Services: General Staff, 1915 Jan.-June, May 1915, Appendix-15.

10 TNA, W.O. 95/4276, 9 CORPS, Headquarters Branches and Services: General Staff, 1915 June - Sept., 24 July 1915.
}

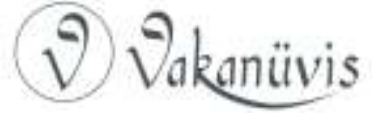


intiyaç duyulan bir başka hammadde olan petrolün Romanya'dan temin edildiği ancak fiyatlar çok yükseldiği için petrol temininde de sıkıntı yaşandığı bu rapora girmiştir. Devamında ise Türkiye'ye petrolün şimdiye kadar İtalyan gemileriyle (Rus filosundan kaçarak) Köstence'den Karadeniz'e getirildiği, bazen de Romanya'dan karayolu ile getirildiği söylenmiştir. "Altın" başlığında ise, Almanların Türklere düzenli olarak altın gönderdiği ve Osmanlı Bankası'nın Konya'ya bir buçuk milyon altın yolladığı, önemli bir miktarın da gönderim için hazır olduğu belirtilmiştir. Altın haricinde, yapılan hesaplara göre ise Almanların Türklere her ay 25 milyon mark verdiği tahmin edilmiştir.

Bu başlıkların altına ise İstanbul ve İzmir'de erzak fiyatlarının "frank" para birimi cinsinden ücretleri tablo şekilde konulmuştur:

\begin{tabular}{|l|l|l|l|}
\hline Et & 1,20 & Pirinç (1 okka) & 1,60 \\
\hline Ekmek & 0,45 & Peynir & 2,40 \\
\hline Yumurta (1 adet) & 0,5 & Mum (kandil) & 0,40 \\
\hline Şeker (1 okka) ${ }^{11}$ & 1,40 & Limon & 0,15 \\
\hline Kahve (1 okka) & 2,50 & Portakal & 0,30 \\
\hline Soğan (1 okka) & 0,50 & Un (1 torba) & 0,30 \\
\hline Patates (1 okka) & 1,20 & & \\
\hline
\end{tabular}

Tablo 1: İzmir Erzak Fiyatları (Fiyatlar Frank para birimi cinsindendir) ${ }^{12}$

Verilen tabloya göre İzmir'de fiyatlar bu şekildeyken İstanbul'da rakamlar daha fazla gösterilmektedir. Savaş sebebiyle ülkenin her yerinde fiyatların arttığı bilinen bir hadisedir. I. Dünya Savaşı başladığında Osmanlı Devleti ekonomik olarak hazır değildi. Devlet, uzun yıllardır aldığı dış borçlarla bir şekilde ayakta kalmaya çalışırken, Balkan Savaşı'nda yaşanan büyük bozgun ekonomiyi daha da kötüleştirmiştir. I. Dünya Savaşı'na girilirken bu savaşın çok uzun süreli olmayacağı hesap edilmiş fakat beklentilerin aksine savaş, dört yıl sürmüştür. Ekonomik şartlar son derece kötüyken dört yıl sürecek bir

\footnotetext{
111 okka $=1.282 \mathrm{~kg}$.

12 TNA, W.O. 95/4304, 29 DIVISION, Headquarters Branches and Services: General Staff, 1915 Jan.-June, May 1915, Appendix-30.
}

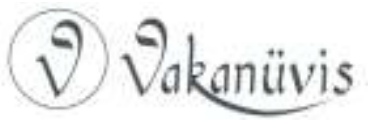


savaş devletin altından hiçbir şekilde kalkamayacağı bir yük demekti. 1918 'e gelindiğinde toprak kayıplarının yanında, ülkenin beşeri ve ekonomi kaynakları da tam olarak tükenmişti.

Boğazların kapatılması ve Çanakkale Boğazı'ndan geçmeyi başararak Marmara'ya giren İtilaf denizaltılarının yarattığı tehdit yüzünden ticaret sekteye uğramış ve dışarıdan ithal edilen ve son derece gerekli olan şeker, un ve gaz gibi ürünlerin fiyatları ciddi şekilde artmıştır. Unun çuvalı, 90 kuruştan 140 kuruşa, kısa bir süre sonra da 300 kuruşa kadar çıkmıştır. ${ }^{13}$ Aynı şekilde çay, 1914 yılında 60 kuruşken 1915 'te 120 kuruşa, 1918 yılında ise 500 kuruşa çıkmıştır. Kahvenin fiyatı ise 1914'te 12 kuruşken $1918^{\prime}$ de 800 kuruşa fırlamıştır. ${ }^{14}$ Enflasyon ve hayat pahalıı̆ı̆, savaş uzadıkça kendisini daha çok belli etmiş ve fiyatlar yukarı çıkmaya devam etmiştir. Karaborsa yaygınlaşmış ve varlıklı aileler bile büyük zorluklar çekmiştir. Halkın en çok tükettiği gıda olan ekmek konusunda sıkıntı yaşanmaması için savaş boyunca İstanbul'da belediye un dağıtımı yapmış ve bunu yaparken de fırınların olduğu mahallelerin nüfus miktarı esas alınmıştır. Alınan tedbirlere rağmen ekmek bir dönem karneyle dağıtılmıştır. ${ }^{15}$ İstanbul'da halkın yaşadığı bu ekonomik sıkıntılar şüphesiz şehirdeki İngiliz ajanları tarafından rahatlıkla gözlenmiş ve rapor edilmiştir.

28 Mayıs tarihli bir başka istihbarat bülteninde ise "istanbul'da Vaziyet" başlığı atıldıktan sonra, şehirde kömür, gaz ve elektrik sıkıntısı yaşandığı, Boğaz hattındaki vapurların sadece yarısının çalıştığı, demiryollarının ise sadece birkaç haftalık tedariki kaldığından bahsedilmektedir. Gerçekten de İstanbul'da ulaşım konusunda sıkıntı yaşanmasının bir sebebi de kömür yokluğudur. Su, elektrik, tramvay ve vapur hizmetleri için günde ortalama 1200 ton kömür gerekmektedir. Kömür eksikliği yüzünden trenler ve diğer nakliye vasıtaları düzgün bir şekilde çalışamamış ve zahire nakledilememiştir. Savaş sırasında

\footnotetext{
${ }^{13}$ Lokman Erdemir, "I. Dünya Harbi'nin İstanbul'da Sosyal Hayata Etkisi”, Birinci Dünya Savaşı'nda Osmanlı Devleti, İstanbul,2015, s.307.

${ }^{14}$ Vedat Eldem, Harp ve Mütareke Yıllarında Osmanlı Imparatorluğunun Ekonomisi, Ankara,1994,s.31.

${ }^{15}$ Alev Gözcü, “I. Dünya Savaşı ve Osmanlı Devleti'nin Gündelik Hayatından Kesitler”, Çağdaş Türkiye Tarihi Araştırmaları Dergisi, XVI/32 (2016-Bahar), s.144.
}

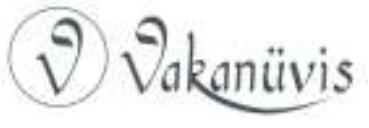


olağandışı koşullar sebebiyle Şirket-i Hayriye önemli sıkıntılar yaşamıştır. Kömür tedariki güçleştikçe şirketin durumu da kötüleşmiştir. ${ }^{16}$

Raporun devamında ise toplumsal hayata dair enteresan bilgiler mevcut. İstanbul'da yaşayan Müslüman ve Hristiyanların gergin olduğu, Ermenilerin hükümete karşı bir komplo tasarladıkları ancak ihanete uğrayarak çok miktarda Ermeni'nin yakalanarak asıldığına dair bilgiler verildikten sonra, Alman Büyükelçiliğinin Boğaz'ın geçilme ihtimaline karşı Eskişehir'e taşınma hazırlığı içinde olduğu belirtilmektedir. ${ }^{17}$ istihbarat bültenlerine yansıyan bir başka önemli konu da Osmanlı coğrafyasında yaşanan siyasi olayların incelenmesidir. Ülkenin dört bir yanından siyasi gelişmelerin verildiği 22 Mayıs 1915 tarihli bültende, Van bölgesindeki Ermeniler ile yaşanan hadiseler üzerinde durularak ve şu tespit yapılmıştır: "Van'daki Ermeni isyanı doğrulanmıştır. Belirtilerin Türklerin isyanı bastırdığı fakat Ermeni katliamını teşvik ettikleri yönündedir."

Bültenin devamında ise Suriye-Mısır-Arap Yarımadası ekseninde yaşanan gelişmeler hakkında istihbarat bilgileri sıralanmıştır. “Mısır'dan gelen raporlar ve hadiseler Türklerin Kanal harekâtını iptal ettiğini gösteriyor" dendikten sonra yerel şeyhlerin (dördü hariç) İngiliz dostu olduğu, Yemen'de "Zaranik" kabilesi şeyhinin mektup yazarak Türklere karşı birlikte savaşmayı teklif ettiği belirtilmiştir. Ingilizlerin 1915 yılından itibaren Arap coğrafyasında çok ciddi istihbarat çalışmaları içinde bulunduğu göz önüne alındığında, bu bölgelerden gelen istihbarat akışının sağlam temellere oturduğunu söylemek mümkün. Zira raporun ilk kısmında Türklerin Kanal harekâtını (Gelibolu'ya yapılan çıkarmalardan sonra) ertelediği ve El-Ariş'ten 500 kişi hariç bütün garnizonun kuzeye kaydırıldığı isabetli olarak raporlara girmiştir. ${ }^{18}$ Bunun yanında Türklerin Suriye ve Mezopotamya'dan Gelibolu'ya kuvvet kaydırıp kaydırmadığının tespiti için yoğun

16 Büşra Karataşer, "Birinci Dünya Savaşı ve Mütareke Döneminde İstanbul'un İaşesi", Kahramanmaraş Sütçü Imam Üniversitesi iktisadi ve Idari Bilimler Fakültesi Dergisi, Haziran 2014 3/2, s. 105.

17 TNA, W.O. 95/4304, 29 DIVISION, Headquarters Branches and Services: General Staff, 1915 Jan.-June, May 1915, Appendix-32.

18 TNA, W.O. 95/4304, 29 DIVISION, Headquarters Branches and Services: General Staff, 1915 Jan.-June, May 1915, Appendix-23.

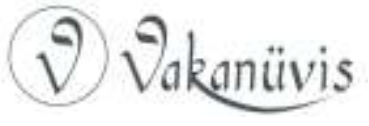


istihbarat çalışmaları yapılmıştır. İstihbarat subaylarından Aubrey Herbert, Mısır'a çektiği telgrafta Suriye'deki Türk birlikleri hakkında bilgi talep ederken şu cümlelerle mesajını bitirmiştir: "Çanakkale'ye doğru herhangi bir kuvvetin gönderilip gönderilmediği ya da gönderilen birlik varsa bunların muhtemel geliş tarihini tespit etmek son derece önemlidir." ${ }^{19}$

Arap bölgelerinde yaşayan aşiretler, kabileler ve bunların reisleri hakkında İngilizlerin ayrıntılı istihbarat raporları tuttuğu bilinmektedir. 1915 başında sahadaki ajanlar ile bölgesel ofisler arasındaki koordinasyon eksikliğinden şikâyet edilse de, 1916 yılında kurulan Arap Bürosu sayesinde İngilizlerin bölgedeki istihbarat faaliyetleri oldukça artmış ve Osmanlı Devleti'ne karşı Arap İsyanı başlatılmıştır. ${ }^{20}$

Bir başka belgede ise Baron von Oppenheim'ın ${ }^{21}$ Halep'te etkili olduğu ve $\mathrm{Kleber}^{22}$ suikastını överek Hristiyanların öldürülmesini teşvik ettiği belirtilmiştir. Eylül 1915 tarihli bir istihbarat bülteninde ise istihbaratın kaynağı son zamanlarda İstanbul ve Suriye'de bulunan bir Avrupalıya dayandırılarak, özellikle İstanbul'da yaşanan gelişmeler hakkında bir rapor hazırlandığını görülmektedir. Bu rapora göre, Türk hükümetinin her şeyin iyi olduğu izlenimini yaratmak için elinden gelen gayreti gösterdiği fakat eğitimli Türklerin genellikle hükümete karşı olduğu belirtilmektedir. "Alman Etkisi" başlığında ise istanbul'daki Alman nüfusu ve gücü hakkında çarpıcı ve abartılı ifadeler yer almaktadır. İstanbul'un sanki Alman istilasına uğradığından söz

19 Peter Chasseaud-Peter Doyle, Grasping Gallipoli, Terrain, Maps and Failure at the Dardanelles 1915, England 2005, s.118.

20 Sait Yılmaz, Türk-Ingiliz Istihbarat Savaşları 1914-1918, Ankara 2017, s.63.

21 İyi derecede Arapça bilen Alman arkeolog von Oppenheim Almanya Dışişleri Bakanlığına bağlı olarak "Şark İstihbarat Birimi"nin kuruluşunu sağladıktan sonra Nisan 1915'te İstanbul'a gelerek bu birime bağlı olarak "Haber/Bilgi" şubesini kurmuştur. Arap bölgelerinde propaganda ve istihbarat faaliyetleri yürütmüştür. Kadir Kon, “Almanya'nın İslam Stratejisi Mimarlarından Max Von Oppenheim ve Bu Konudaki Üç Memorandumu", Tarih Dergisi, Sayı 53, (2011 / 1), s.240.

22 Napolyon'un Mısır'ı işgal etme sürecinde yanında en güvendiği generallerden olan Kleber daha sonra Fransa adına Mısır'da tek yetkili konumuna gelmiş ve 20 Mart 1800 tarihinde Heliopolis'te sadrazam komutasındaki Osmanlı ordusunu mağlup etmiştir. Fakat 14 Haziran 1800 tarihinde Halep'li bir genç tarafından öldürülmüştür. Kamil Koçak, "Mısır'ın Fransızlar Tarafından İşgali ve Tahliyesi (1798-1801)", SAÜ Fen Edebiyat Dergisi, (2008-II), s. 161-162.

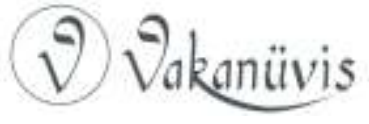


edilirken, eğitimli Türklerin ifadelerine göre, İstanbul'a 300.000 Alman gelirse (böyle bir söylenti vardır) bunların bir daha şehri terk etmeyecekleri ve eğer Türkler esir veya köle olacaksa Almanları değil Ingiliz veya Fransızları tercih edecekleri ifade edilmiştir. Haber kaynağı Avrupalının verdiği bilgilere göre İstanbul'dan çok sayıda Türk ve Alman subayın cepheye gittiği, şehirde eğitimli asker kalmadığı ve her yerin acemi askerlerle dolu olduğu, ayrıca 45 yaşına kadar herkesin askere çağrıldığı belirtilmiştir.

Raporun en sonunda ise Ingiliz esirlerinin durumu hakkında bir madde açılarak, ABD konsolosluğundan alınan bilgiye göre Türklerin esirleri öldürdüğüne dair bir kanıt bulunmadığı, Afyon'a gönderilen esirlerin durumunun iyi olduğu ve $A B D$ elçiliğinden bir görevlinin bölgeye gitmesiyle şartların iyileştirildiği bilgisi verilmiştir. ${ }^{23}$ Türklerin eline düşen İngiliz yaralı ve esirlerin durumu üzerinde İngiltere'de önemle durulmuştur. $O$ tarihlerde tarafsız olan ABD Büyükelçiliğinden Hoffman Philip, 11 Ağustos 1915'te Afyonkarahisar'daki savaş esirlerini beşinci kez ziyaret etmiş ve esirler hakkında Ingiltere'ye bilgi vermiştir. ${ }^{24}$ Afyon'daki şartlar ilk başlarda kötü olsa da, imkânlar çerçevesinde savaşın son yıllarına doğru şartların daha iyiye gittiği İngiliz raporlarına girmiştir. Bu raporlarda 1915-1916 yıllarında esir kampları hakkında olumsuz ifadeler göze çarparken 1918'e gelindiğinde ise olumlu ifadelerin çoğaldığı görülmektedir. Zira şartların iyiye gittiği ve esirlerin makul bir esaret hayatı yaşadıkları burada tutulan İngilizlerin mektuplarına ve günlüklerine de yansımıştır. Esirlerin büyük kısmı yazdıkları mektuplarda kendilerini iyi hissettiklerini ve Afyon'un güzel bir yer olduğu belirtmiştir. Uzun süren savaşın zorlu şartları göz önüne alındığında Osmanlı Devleti'nin esirlere elinden geldiği kadar iyi baktığı söylenebilir. Bu husus İngiliz raporlarına da yansımıştır. ${ }^{25}$ Esir kamplarındaki şartların eldeki imkânlar ölçüsünde geliştirilmeye çalışıldığı Hollanda'nın İstanbul Büyükelçiliğinde görevli olup Afyon'a İngiliz esirlerinin durumunu gözlemlemek için gönderilen

23 TNA, W.O. 95/4305, 29 DIVISION, Headquarters Branches and Services: General Staff, 1915 July-1916 Feb., September 1915, Appendix-7.

24 Feyza Kurnaz Şahin, "İngiliz Arşiv Belgelerine Göre I. Dünya Savaşı Yıllarında Afyonkarahisar Üsera Garnizonu'ndaki Ingiliz Esirler”, A. Ü. Türkiyat Araştırmaları Enstitüsü Dergisi, Erzurum 2016, s.1260.

${ }^{25}$ a.g.m, s.1302.

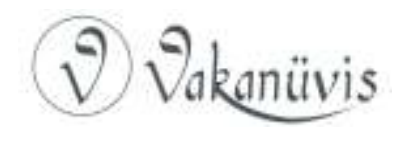


2 görevlinin raporlarından da anlaşılmaktadır. Savaşın sonlarına doğru 1917 ve 1918 yıllarında tutulan bu raporlar İngiltere'ye gönderilmiştir. Genel itibariyle Afyonkarahisar kampıyla ilgili eksiklikler dile getirilmiş, ancak bunun yanında esirlerin genel durumunun iyi olduğu, Afyonkarahisar Üsera Garnizonu'nda esirlere sağlanan şartların gayet muntazam göründüğü, Osmanlı yöneticilerinin kampın şartlarını iyileştirmek hususunda gayret gösterdiği vurgulanmıştır. Keza Osmanlı Devleti'nin savaş mağduru olan esirlere karşı yaklaşımının uluslararası anlaşmalara uygun olduğu, yeni düzenlemelerle esirlerin yaşantılarının daha sağlıklı koşullara ulaştırıldığının altı çizilmiştir. ${ }^{26}$

29. Tümen'in Ekim ayındaki bir başka istihbarat bülteninde ise Mezopotamya bölgesinde yaşananlar, özellikle 26-28 Ekim 1915 tarihinde gerçekleştirilen Kut'ül Amare bölgesindeki çarpışmalar hakkında ayrıntılı bilgiler verildiği görülmektedir. Raporda bahsedilen muharebe I. Kut'ül Amare muharebesidir. General Townshend komutasındaki İngilizler, Nureddin Bey komutasında Kut'ül Amare'yi savunan Türk kuvvetlerine taarruza kalkmış, şiddetli İngiliz taarruzu neticesinde eldeki mevcut birliklerle bölgenin savunulamayacağını anlayan Nureddin Bey düzenli bir ricat hareketiyle Selman-ı Pak bölgesine çekilmiştir. İngiliz ordusunun takibinden kurtularak Kut'ül Amare'ye 150 km. mesafedeki Selman-ı Pak'a toplu bir halde gelinmesi hakikaten askeri bir başarıdır. ${ }^{27}$ Nitekim istihbarat bülteninin sonunda, Türklerin çarpışarak başarılı şekilde geri çekilmesi hakkında şunlar söylenmektedir: "Türkler dikkatli ve bilimsel bir şekilde planlanmış ve modern prensiplere göre hazırlanmış bir pozisyonda büyük bir azim ile savaştılar"28

İstanbul'daki genel vaziyete dair yazılan istihbarat raporlarında ağırlıklı olarak öne çıkan konulardan biri de, Çanakkale Muharebeleri başladıktan sonra İstanbul'a akın akın getirilen Türk yaralılarıdır. Yaralılar konusunun neredeyse her istihbarat bülteninde yer aldığı

26 Feyza Kurnaz Şahin, "I. Dünya Savaşı Yıllarında İki Felemenk Temsilcinin Afyonkarahisar Üsera Garnizonu Hakkındaki İzlenimleri: Dirk Johannes Van Bommel ve Dr. Emile Ernest Menten Raporları", Çanakkale Araştırmaları Türk Yıllığı, Yıl: 14, Bahar: 2016, Sayı: 20, s.59.

27 Muzaffer Albayrak-Vahdettin Engin, Kutulamare Zaferi 1916, İstanbul 2017, s.80.

28 TNA, W.O. 95/4305, 29 DIVISION, Headquarters Branches and Services: General Staff, 1915 July-1916 Feb., October 1915, Appendix-11.

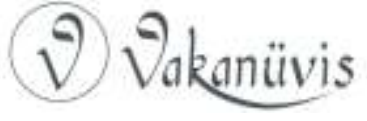


göze çarpmaktadır. Buradaki amaç, İstanbul ve çevre bölgelere sevk edilen yaralıların sayısının hesaplanarak, Çanakkale'de savaşan Türk birliklerinin tahmini zayiatını öğrenmektir. Yaralı sayısı raporlarda genellikle abartılı olarak hesaplanmakla birlikte, İstanbul'da bunları yerleştirecek mekân sıkıntısı ile birlikte sağlık personeli sıkıntısı çekildiği, okulların, hatta özel mülklerin bile yaralılarla dolup taştığı bilgisi hemen her istihbarat raporunda yer almaktadır.

26 Mayıs 1915 tarihli istihbarat bülteninde, 2 Mayıs-12 Mayıs tarihleri arasında sadece i̇stanbul'a getirilen yaralı sayısı 23.000 olarak verildikten sonra, ciddi miktarda yaralının da gemilerde Marmara'nın çeşitli limanlarında bekletildiği belirtilmiştir. Başka bir raporda ise, İstanbul'a 20 Mayıs'a kadar toplam 35.000 yaralı getirildiğinin hesaplandığı, Çanakkale'de savaşın ilk sekiz gününde 20.000 Türkün yaralandığı bilgisi eklenmiştir. İzmit ve Erdek'te bu dönemde 10.000 yaralı olduğu, toplam (ölü ve yaralı) zayiatın ise 70.000 kadar olduğu belirtilmektedir. ${ }^{29}$ Savaşın ilerleyen aşamalarında da istihbarat bültenlerine tahmini Türk yaralı sayısı sürekli girmiştir. Türk kaynaklarına baktığımızda yaralı konusu ile ilgili en açıklayıcı bilgileri Dr. General Kemal Özbay'ın verdiği görülmektedir. Türk Asker Hekimliği Tarihi ve Asker Hastaneleri adlı eserinde, 25 Nisan-1 Temmuz 1915 tarihleri arasında Akbaş ve Akdere hastaneleri aracılığıyla toplam 56.394 yaralı ve 2358 hastanın, Temmuz-Ağustos 1915 aylarında ise 30.463 yaralı, 13.701 hastanın tahliye edildiğini belirtmektedir. ${ }^{30}$ Sonbahar aylarında ise bu sayı 12.416 yaralı, 15.735 hasta ve 15.255 olmak üzere toplam 43.406'ya çıkmıştır.

Muharebeler başladıktan sonra gerçekten de İstanbul'a on binlerce yaralı getirilmiş ve bunların bakımı için şehirde neredeyse seferberlik ilan edilmiştir. Aslında bu durum Türk yetkililer tarafından tahmin edilmiş ve muharebeler başlamadan önce i̇stanbul'da çok sayıda okul (askeri okullar hariç) hastaneye çevrilmiş ve hastalar için binden fazla

\footnotetext{
29 TNA, W.O. 95/4304, 29 DIVISION, Headquarters Branches and Services: General Staff, 1915 Jan.-June, 26 May 1915.

${ }^{30}$ Kemal Özbay, Türk Asker Hekimliği Tarihi ve Asker Hastaneleri I-II, İstanbul 1976, C.I, s.233-234.
}

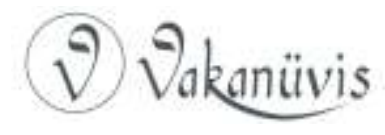


yatak kapasitesi olan yeni yerler hazırlanmıştır. ${ }^{31}$ Muharebelerin başlamasıyla ordu ve Kızılay'ın yardımları ile (Balkan savaşında olduğu gibi) resmi-özel okul ve kurumların hastane haline getirilmesine devam edilmiştir. ${ }^{32}$ Çok sayıda sultani hastaneye dönüştürülerek hizmet vermeye başlamıştır. Sağlık Dairesi istatistik şubesinde Dr. Rıfkı Bey'in verdiği rakamlara göre 1916 sonuna kadar İstanbul'daki 47 hastanede 124.343 yaralı, 247.906 hasta tedavi görmüştür. ${ }^{33}$

Tabi ki İstanbul'a gönderilen yaralılar ve hastane sıkıntısı İngilizlerin gözünden kaçmamış ve istihbarat raporlarına olduğu gibi yansımıştır. İstihbarat bültenlerinde okulların, hatta evlerin hastaneye çevrildiği belirtildikten sonra, uzman doktor ve ilaç sıkıntısı çekildiği, hükümetin hasta ve yaralıların tedavisinde medikal ihtiyaçları karşılamakta oldukça zorlandığı yazmaktadır. İngiliz İstihbaratına göre, Zografyon Rum Lisesi, Zapyon Lisesi ve Rum-Hellen Koleji gibi azınlık okulları da hastaneye çevrilmiştir. Zapyon Lisesi başöğretmeninin verdiği bilgiye göre, okulda yerleri temizlemek için bile zaman olmadığı, yatak çarşaflarının yanı sıra, bazı kız öğrencilerin iç çamaşırlarının alınarak bandaj yapmak için ayrıldığı belirtilmektedir. ${ }^{34}$

\section{Çanakkale Muharebeleri Hakkında İstihbarat Raporları}

Hiç kuşku yok ki istihbarat raporlarının çok önemli bir bölümü muharebeler hakkında verilen bilgilerden oluşmaktadır. Bu istihbarat raporlarını iki ana başlık altında incelemek doğru olacaktır. Öncelikle değerlendirilmesi gereken raporlar, kuşkusuz, çıkarmalar başlamadan önce bölgenin coğrafi özellikleri hakkında, yani arazinin avantajlarıdezavantajları, koylar, bitki örtüsü, ulaşım imkânları, yollar, su kaynakları vs. gibi pek çok konu hakkında tutulan ayrıntılı istihbarat raporlarıdır. Daha sonra ise Çanakkale Boğazı bölgesinde bulunan Türk birliklerinin hangi noktalarda bulunduğu, hangi kıyıların daha güçlü, hangi kıyıların daha zayıf savunulduğu, Türk askeri birliklerinin niteliği, yedek kuvvetleri ve sayısı hakkında hazırlanan istihbarat raporları

\footnotetext{
${ }^{31}$ Mustafa Selçuk, Çanakkale Seferberliği, Savaş, Eğitim, Cephe Gerisi, Kitap Yayınevi, İstanbul 2016, s.108.

32 Özbay, a.g.e, c.l, s.233.

33 a.g.e, c.l, s.238.

34 TNA, W.O. 95/4304, 29 DIVISION, Headquarters Branches and Services: General Staff, 1915 Jan.-June, May 1915, Appendix-30.
}

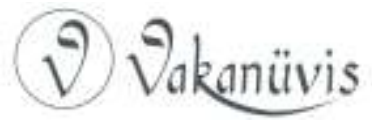


önem teşkil eder. Muharebeler başladıktan sonra ise raporların içeriği değişmiştir. Gelibolu'ya çıkarma yapıldıktan sonra, Akdeniz Seferi Kuvvetleri Genel Karargâhında çalışan İstihbarat birimi kendi içinde "Ia" ve "I-b" bölümleri olarak ikiye ayrılmıştır. Bunlardan ilki Türkler hakkında bilgi toplamak için çalışırken, ikincisi Türklerin İngilizler hakkında bilgi toplamasını önlemek (karşı istihbarat) için çalışmalarını sürdürmüştür. ${ }^{35} \mathrm{I}-\mathrm{a}$ ve $\mathrm{I}-\mathrm{b}$ birimleri daima Atina'daki büro ile temas halinde olmuştur. Bu birimler, muharebeler bütün şiddetiyle devam ederken Türk ordusu hakkında genel bilgilerin toplandığı, yani İtilaf Kuvvetleri karşısında hangi Türk birliklerinin olduğu, Türk komuta kademesinin kimlerden oluştuğu, Türklerin zayiatları, moralmotivasyonu ve Türk savunmasına dair istihbarat raporları hazırlamıştır.

Son olarak, muharebeler devam ederken İngilizlere esir düşen veya firar eden Türk askerlerinin verdiği ifadelerden elde edilen bilgilerle hazırlanan ayrıntılı raporlar da oldukça dikkat çekici niteliktedir.

\section{Muharebeler Başlamadan Önce Yapılan İstihbarat Çalışmaları}

Bilindiği gibi Çanakkale Boğazı dünyada üstüne en çok çalışılan en stratejik ve önemli suyollarından biriydi. Rusya'yı Akdeniz'den uzak tutmakla ilgilenen İngilizler, ellerine geçen her fırsatta Çanakkale Boğazı ve Gelibolu Yarımadası ile ilgili gözlemler ve çalışmalar yapmışlardır.

19. Yüzyılda Çanakkale Boğazı'ndaki ilk düşmanca faaliyet I. Dünya Savaşı'ndan 107 yıl önce, 1807 yılında Amiral Duckworth komutasındaki İngiliz donanmasının Boğaz'ı geçmesiyle başlamıştır. Donanma, İstanbul önlerine gelmiş fakat yanında kara birliği olmadığı için İstanbul üzerinde herhangi bir etki yapamayarak geri dönmüştür. İngilizler, 20. Yüzyılın başlarında da Çanakkale Boğaz'ı hakkında çeşitli raporlar hazırlanmış ve bu raporlarda Boğaz'ı zorlayarak geçmenin çok tehlikeli olduğu sonucuna varmışlardır. 1906 yılında yapılan en kapsamlı ve ayrıntılı araştırma sonucu Savaş Bakanlığına sunulan

35 Genel karargâhta İstihbarat birimi İngilizcede istihbarat anlamına gelen "Intelligence" kelimesinin ilk harfi olan "(I)" harfi ile anılmıştır. Diğer birimlere verilen harfler ise şöyledir: Operasyonlar (O), İdari işler (A), Levazım (Q). Compton Mackenzie, Gallipoli Memories, New York 1930, s.44.

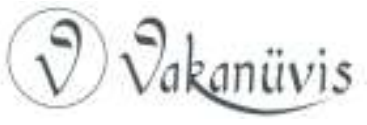


raporun son cümlesinde şöyle denmektedir: "Görülen riskler nedeniyle genelkurmay bu harekâta girişilmesini tavsiyeye hazır değildir." 36

1915'e gelindiğinde ise Çanakkale'ye harekât yapılmadan önce bu harekâtın sadece denizden mi yoksa kara-deniz kuvvetlerinin müşterek operasyonu ile mi yapılacağı İngiltere'de masaya yatırıımıştır. Fakat yapılacak olan harekâta kara ordusundan yeterli miktarda birlik ayrılamayacağı tespit edilmiş ve Çanakkale Boğazı'nı sadece savaş gemileriyle geçmeye çalışma planı üzerinde mutabakat sağlanmıştır. ${ }^{37}$ Amirallik Birinci Lordu Winston Churchill'in ısrarlı girişimleri sonucu, 13 Ocak 1915'teki Savaş Konseyi'nde Çanakkale Boğazı'nı sadece denizden zorlama planı kabul edilmiştir. Fakat daha sonra Çanakkale'deki Türk savunmasını analiz eden 15 Şubat 1915 tarihli Amirallik raporuna göre, Türk tabyaları ve kıyı savunmalarını işgal edip bölgeyi güvence altına almak için askeri birliklerin de harekâta katılması şiddetle tavsiye edilmiş, bunun üzerine 16 Şubat'ta yapılan kabine toplantısında, kara kuvvetlerinin de hazırlanmasına karar verilmiştir. ${ }^{38}$ Bölgeye gönderilecek askeri birliklerin asıl görevi karaya çıkarak bir işgal hareketine girişmek değil, ufak çıkarma grupları halinde kıyılardaki Türk tabyaları ve sahillerin güvenliğini sağlamaktan ibaretti. Bilindiği gibi, İngilizler, 18 Mart 1915 tarihinde filonun Çanakkale Boğazı'nı geçme teşebbüsünün büyük bir başarısızlıkla sonuçlanmasıyla, kara ordusunun devreye girmesi gerektiğine karar verdiler. Karaya büyük çapta birlikler çıkarılmadan sadece gemilerle Çanakkale'nin geçilemeyeceği çok net ve acı şekilde anlaşılmıştı. Bundan sonra bütün dikkatler ordunun hızlı bir şekilde karaya başarılı bir çıkarma yapmasına odaklanacaktı.

Aslında Çanakkale Boğazı ve çevresi İngilizlerin yabancı olduğu bir bölge değildi. 1799'da Napolyon'un Mısır'a saldırması üzerine İstanbul'a gelen "İngiliz Askeri Misyonu" Çanakkale Boğaz'ını çevreleyen kaleleri, bataryaları, savunma hatları ve cephanelikleri incelemek için bölgeye gönderilmiş ve hazırlanan rapora göre Boğaz

\footnotetext{
${ }^{36}$ Nigel Steel, Peter Hart, Gelibolu Yenilginin Destanı, Çev: Mehmet Harmancı, İstanbul 2005, s.19.

${ }^{37}$ Figen Atabey, Çanakkale Muharebelerinin Deniz Cephesi, Ankara 2014, s.46.

38 Mehmet Kıbıl, Çıkarmadan Tahliyeye Arıburnu Anafartalar Muharebeleri, İstanbul 2017, s.3.
}

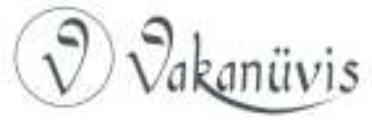


savunmasının tamamen yetersiz olduğunu tespit etmişlerdir. ${ }^{39}$ Ingilizler böylece İstanbul ve Çanakkale boğazlarının askerî durumu ve savunması hakkında birinci elden bilgilere sahip olmuştur. ${ }^{40}$ Kuşkusuz 1799 'da hazırlanan rapordaki savunma tertibatı ile 1915'teki şartlar aynı değildir fakat bu ziyaret esnasında İngiliz subaylarının bölgenin coğrafi konumunu ve özelliklerini yakından inceleme fırsatını buldukları da gerçektir. İngilizlerin bölgedeki faaliyetleri bu tarihten itibaren artarak devam etmiştir.

Daha sonra Kırım Savaşı'nda Türklerle birlikte Ruslara karşı savaşan İngiliz ve Fransızlar, Karadeniz'e giden deniz yolunu güvenceye almak için Gelibolu Yarımadası ve Çanakkale bölgesinde konuşlanmışlardır. İngilizler bu savaş esnasında da yaptıkları keşif ve incelemelere dayanan orta ölçekli bir harita da dahil olmak üzere çok sayıda stratejik, taktik ve topografik istihbarat bilgisine sahip olmuşlardır. Hatta kuzeyden gelecek bir Rus tehdidine karşı Gelibolu Yarımadası'nı savunmak için Bolayır'a bir savunma hattı planı tasarlamışlardır. ${ }^{41}$

1876 yılına gelindiğinde ise Osmanlı-Rus harbi esnasında istihkâm subayları Yarbay Home ve Yüzbaşı Fraser, İngiltere Dışişleri Bakanlığı tarafından İstanbul'a yollanmışlar ve bu subaylar Gelibolu'ya batıdan gelecek bir saldırıya karşı savunma tertibatı ve filonun Çanakkale Boğazı'ndan rahatça geçebilmesi için Yarımadayı tutma planları hazırlamışlardır. Bu çerçevede Savaş Bakanlığına verilmek üzere "çok gizli" ibaresiyle içinde Gelibolu Yarımadası ile alakalı çok sayıda harita ve plan olan bir kitapçık hazırlanıp bastırılmıştır. Kitapçığın ismi "Istanbul ve Türkiye'deki diğer bölgelerin savunması ve ayrıca Rumeli'deki güzergâhlara ilişkin raporlar ve bildiriler" dir. ${ }^{42}$ Daha sonra Genelkurmay başkanlığı yapacak olan Feldmareşal Sir William Robertson da Gelibolu Yarımadası'nı ele geçirme ile ilgili planların

39 William Wittman, Travels in Turkey, Asia-Minor, Syria and Across the Desert into Egypt during the Years 1799, 1800 and 1801, Londra 1803, s. 56-57.

40 Fatih Yeşil, "İstanbul Önlerinde Bir İngiliz Filosu: Uluslararası Bir Krizin Siyasî ve Askerî Anatomisi", Nizam-ı Kadim'den Nizam-ı Cedide III. Selim ve Dönemi, Ed. Seyfi Kenan, İstanbul 2010, s. 414.

${ }^{41}$ Chasseaud-Doyle, a.g.e, 50.

42 a.g.e., s.51-52.

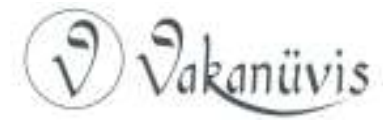


1914'ten çok önceye, İstanbul'un neredeyse Rusların eline düşmek üzere olduğu 1878 yılına kadar uzandığını belirtmektedir. ${ }^{43}$

1906 yılındaki Çanakkale Boğaz'ı ile ilgili ayrıntılı raporu yazan ekipte olan ve 1915 'te İngiliz ordusunda kritik görevler üstlenen General Callwell, o dönemde bölge ile ilgili nasıl bilgi toplandığını şöyle anlatmaktadır:

"O zamanlar Askeri Operasyonlar Müdürlügünün strateji bölümünden ben sorumluydum ve askeri çizgide neler yapabileceğimizi düşünürken, Çanakkale Boğazı'na sahip olmak için önümüze çıkabilecek problemleri araştırmıştım. Dahası birkaç yıl önce, Boğazdan geçerken bir geceyi Çanakkale'de geçirdim. Araziyi yapısı, mevcut top bataryaları ve diğer önemli hususlar hakkında çok önemli notlar aldım." ${ }^{\prime 4}$

1908 'de II. Meşrutiyetin ilanından sonra donanma ile ilgili ıslah çalışmaları işinin İngilizlere verilmesi kararlaştırılmış ve bu amaçla Ingiltere'den Amiral Gamble, Limpus ve Williams adlı üç amiral görevlendirilmiştir. ${ }^{45} \mathrm{Bu}$ tarihten itibaren donanmada İngiliz subay ve teknikerlerinin ağırlı̆̆ı git gide artmıştır. Hatta Amiral Limpus başkanlığındaki İngiliz deniz heyeti, I. Dünya Savaşı başlayıp Osmanlı Devleti seferberlik ilan ettikten sonraki dönemde dahi, son ana kadar henüz İstanbul'dan ayrılmamış durumdaydılar. Dolayısıyla 1909-1914 yılları arasında Osmanlı Bahriyesinde görev yapan İngiliz amiral ve askerlerinin Çanakkale Boğazı'nın savunma tertibatıyla ilgili ayrıntılı bilgi sahibi oldukları da çok açıktır. ${ }^{46} 1908^{\prime}$ de Donanma İstihbaratı ve 1909'da Savaş Bakanlığı Gelibolu Yarımadası'nda uygun çıkarma noktalarını rapor haline getirmiştir. Bu tarihten sonra da bölge hakkında bilgi akışı sağlanmış ve düzenli olarak güncellemeler yapılmıştır.

Bütün bu bilgiler ışığında açıkça görülüyor ki Çanakkale bölgesi ve Gelibolu Yarımadası'nın temel coğrafi özellikleri ve savunma tertibatı Ingilizlerin yabancı olduğu veya hiç bilmediği bir konu değildir.

\footnotetext{
${ }^{43}$ William Robertson, Soldiers and Statesmen 1914-1918., Vol. 1, London 1926, s.77.

${ }^{44}$ Charles Edward Callwell, Experiences of a Dug-Out 1914-1918, London 1920, s.87.

${ }^{45}$ Afif Büyüktuğrul, Osmanlı Deniz Harp Tarihi, İstanbul 1983, c.III, s.224.

${ }^{46}$ Atabey, a.g.e, s.56.
}

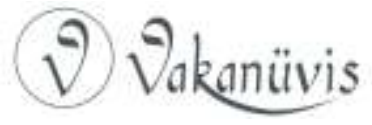


Dolayısıyla, 1915 yılında Çanakkale-Gelibolu bölgesinin coğrafi özellikleri ile ilgili askeri istihbarat raporlarına giren bilgilerin çoğu doğru şekilde saptanmıştır. Bu raporlar Akdeniz Seferi Kuvvetleri genel karargâhında toplanmış ve Yarımadaya çıkacak olan tümenlere istihbarat bültenleri ve günlükleri olarak yollanmıştır.

Örneğin, "Gelibolu Yarımadası'ndaki Köyler, Yollar ve Su Kaynakları" başlıklı son derece ayrıntılı bilgilerin verildiği istihbarat bülteninde ilk olarak Rum köyleri ile ilgili bilgiler yer almaktadır. Buna göre Saroz Körfezi tarafındaki dört köy zikredildikten sonra iç tarafta kalan Kirte [Alçıtepe] ve Maydos [Eceabat] köylerinde yaşayanların zorunlu göç ettirildiği ve bu köylerin Türk askerleriyle doldurulduğu belirtilmektedir. Bu köylerde yaşayan sivil halk savaş başlamadan önce hem güvenlik amaçlı hem de casusluk faaliyetlerine karşı tahliye edilmiştir. İkinci başlıkta ise yarımadada mevcut "yollar" ile ilgili ayrıntılı bilgiler göze çarpmaktadır. Gelibolu-Maydos yolunun en son 1914 'te onarıldığı ve ağır topçunun geçebileceği hale getirildiği, bu güzergâhta Hanouk Bey [?] çiftliği karşısından geçen yolda üç adet çeşme olduğu ve su sıkıntısı olmadığı belirtilmiştir. Yine Maydos'tan Tayfurköy, Turşunköy, Küçük Anafarta, Bigalı'ya kadar bütün köylerin yol ve su durumları ile birbirlerine olan mesafeleri belirtildikten sonra, Gelibolu-Maydos arasında Kilye-Bigalı-Yalova gibi pek çok köyü içine alan üçüncü bir yoldan da bahsedilmiştir. Diğer önemli yol başlıklarında Gelibolu-Yeniköy, Gelibolu-Bolayır arasında olan ana yol ve alternatif yollar ile bu yolların birbirlerine olan mesafeleri (arada kalan köylerin birbirlerine mesafeleri dahil) sıralanmıştır. Bütün bu bahsedilen yollar üzerindeki stratejik noktalar, yolların durumu, çeşmeler, hangi büyüklükte birliğin hangi iklim şartlarında ne kadar sürede bu yolları aşabileceği gibi son derece ayrıntılı bilgiler de raporun içinde yer almaktadır.

"Su kaynakları" başlığında da yarımadada bulunan çeşme ve kuyular hakkında bilgiler verilirken, özellikle su kuyularından kaçınılması gerektiği, Türklerin muhtemelen kuyuları Balkan Savaşı'nda olduğu gibi zehirleyebilecekleri belirtilmiştir. Raporun en son sayfasında genel değerlendirme bölümünde ise bölgenin coğrafyası ile ilgili önemli bilgiler mevcuttur. Yarımadanın yüksek kesimlerinde orman olmadığı, çalı çırpıların boyunun 1 ile 1,5 metreyi civarında

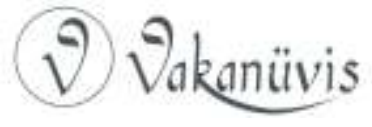


olduğu tespit edildikten sonra, arazinin çoğunun ekili olduğu ve süvariler için yem sorunu yaşanmayacağı belirtilmiştir. ${ }^{47}$

Gelibolu Yarımadası ile ilgili hazırlanan istihbarat raporlarının en önemli haber kaynağı daha önce buradaki köy ve ilçelerde yaşayan fakat I. Dünya Savaşı'nın başlamasıyla Yunanistan (Yunan adaları) ve Avrupa'ya göç ettirilen Rum ve Ermeni göçmenlerdir. Örneğin, 29 Mayıs 1915 tarihinde Kirte'den göçen bir Rum'un verdiği bilgilere göre, taze su kaynakları, köyler ve kasabalar arasında mevcut yollar ile arazi yapısı hakkında ayrıntılı bir rapor hazırlanmıştır. Benzer konularda pek çok Rum göçmenin ifadeleri çeşitli raporlara girmiştir. Ayrıca Boğaz Muharebesinin olduğu 18 Mart 1915 tarihinde, Filo Komutanı Amiral De Robeck'in Hamilton'a gönderdiği gizli bir mesajdan da Rumlardan önemli istihbarat desteği alındığı görülmektedir. Bu mesajda Atina'daki Ingiliz temsilcisinden alınan bilgilere göre; Rusya'nın eski Çanakkale konsolos yardımcısının Atina'da olduğu ve Atina loncasından kayıkçıların Gelibolu'da rehberlik yapmak için eski kaçaklardan faydalanabileceği teklifi yaptığını belirtmiş ve mesajın devamında Hamilton'a bunları hizmete almak isteyip istemediği sorulmuştur. ${ }^{48}$

Bölgeyi iyi bilen ve Türkçe konuşan Rum göçmenler İngilizler için değerliydi ve Gelibolu'da bunların verdikleri her çeşit bilgiden ve rehberliklerinden savaş boyunca faydalanıldı. Örneğin Ağustos ayında başlayan, İngilizlerin Sarıbayır Harekâtı dedikleri ConkbayırıKocaçimentepe hattını ele geçirme operasyonunda, gece karanlığında son derece sarp arazide ilerleyen birliklerin başında Rum rehberler ${ }^{49}$ vardı. Aralarından bazıları bölgede doğup büyüdüğü için Gelibolu bölgesini gerçekten çok iyi bilmekteydiler. Bu Rumlardan biri olan Athanasios Ballas'ın, 16 Nisan tarihinde verdiği çok değerli bilgiler rapor halinde genel karargâha gönderilmiş ve kayıtlara girmiştir. Raporda Athanasios Ballas için not olarak "Bu adam Yarımadayı çok iyi biliyor" ifadesi de yer almıştır. 18 Nisan tarihinde Anzak kolordusuna

47 TNA, W.O. 95/4304, 29 DIVISION, Headquarters Branches and Services: General Staff, 1915 Jan.-June, April 1915, Appendix-8.

48 TNA, W.O. 95/4263, MEF General Headquarters: Branches and Services, General Staff 1915 Feb. - Apr., March 1915, Appendix-10.

${ }^{49} \mathrm{Bu}$ harekât esnasında birlikler karanlıkta başlarında bu Rum rehberler olduğu halde ilerlemeye çalışırken sık sık kaybolmuşlar ve harekât planının oldukça gerisine düşmüşlerdir.

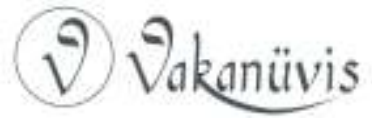


gönderilen iki Rum rehber için ise "Türklerden yoğun şekilde nefret etmelerine rağmen hiç güvenilir değiller" denmektedir. ${ }^{50}$

Rumlardan sadece rehberlik için faydalanılmamıştır. İngiliz istihbarat subaylarının yanında çalıştıılarak ele geçirilen Türk esirlerin sorgulanması esnasında da tercümanlık hizmetinde bulunmuşlardır. ${ }^{51}$ Fakat belgelerin içeriğine bakıldığında bazı yerli Rumlara hiçbir zaman tam olarak güvenilmediği anlaşılmaktadır. ${ }^{52}$ Örneğin, 10. Tümen 30. Tugaya tercüman olarak gönderilen Cristo Farvalas isimli Rumun, meşru görevlerini aksattığı ve güven vermediği gerekçesiyle kolordudan değiştirilmesi ve bir daha tümene gönderilmemesi

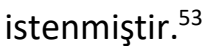

Osmanlı yöneticileri de buralarda yaşayan azınlıkların casusluk faaliyetlerinin farkındaydı ve bunlara karşı çeşitli tedbirler almışlardı. Konu, hazırlanan raporlarla üst makamlara iletilmekteydi ve bunun neticesinde Çanakkale'de bazı yabancı konsolosluklar kapatılmış, Gelibolu Yarımadası'ndaki Rum köyleri boşaltılmış ve Çanakkale'deki azınlıkların (sağlık problemleri haricinde) yurt dışına çıkmaları, yurt dışındakilerin de yurtiçine girişleri engellenmiştir. ${ }^{54} \mathrm{Bu}$ tedbirlere

\footnotetext{
50 Chasseaud, Doyle, a.g.e., s.117-118.

51 Herbert, a.g.e, s.124-125.

52 Gelibolu'daki İngiliz istihbarat subaylarının günlüklerine baktığımızda Rumlardan sadece rehberlik ve tercümanlık işlerinden faydalanılmadığı görülmektedir. İstihbarat subayı Compton Mackenzie günlüğünde aktardığına göre, Bozcaada'da yaşayan Rumlar para karşılığı Boğaz'ın girişindeki Kumkale bölgesine çıkarak casusluk faaliyetlerinde bulunmuş, İngilizler için bilgi toplamaya çalışmışlardır. Örneğin Temmuz ayında, Fransız General Gouraud'nun Asya tarafındaki Türk topçuları tarafından açılan ateşle yaralanması sonucunda Asya sahillerine 5 tane Rum gönderilmiştir. Bu Rumlar bütün gün Truva harabeleri civarında saklandıktan sonra Türk toplarının yerlerini keşfetmeye çalışmış fakat hiçbir bilgi elde edemeden geri dönmüşlerdir. (Günlükte belirtilene göre Rumlara bu iş için adam başı 5 pound verilmiştir. Türk toplarıyla ilgili işe yarar bilgi getirilirse vadedilen ücret 100 pounddur ve bunun yarısı İngilizler yarısı Fransızlar tarafından verilecektir) Mackenzie, a.g.e, s.208-209.

Aynı şekilde, bir diğer istihbarat subayı Geedes de Fransızların getirdiği Giritlilerin bilgi toplamak için Saroz bölgesinden karaya çıkarıldığını anılarında yazmaktadır.

53 TNA, W.O. 95/4276, 9 CORPS, Headquarters Branches and Services: General Staff, 1915 June-Sept., 1 September 1915.

${ }^{54}$ Burhan Sayılır, "Çanakkale Savaşları Sırasında Casusluk Olayları ve Türklerin Casusluk Olaylarına Karşı Aldıkları Tedbirler”, Askeri Tarih Araştırmaları Dergisi, Ağustos 2006, Yıl:4, Sayı:8, s.100-101.
}

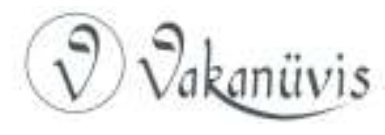


rağmen İngilizlerin Çanakkale civarındaki adalarda ve anakarada bulunan casuslarını etkili şekilde kullandığı görülmektedir. Azınlıkların casusluk faaliyetleriyle ilgili pek çok belge Osmanlı arşivlerinde de mevcuttur.

Diğer yandan, istihbarat raporları incelendiğinde İngilizlerin sadece daha önce bölgede yaşamış veya yaşayan gayrimüslimlerden faydalanmadığı, Türklerden de bilgi aldığı, hatta ve hatta Türk ordusunun içine kadar sızdığı görülmektedir. Akdeniz Seferi Kuvvetleri genel karargâhının Mart ayındaki istihbarat günlüklerinde son derece çarpıcı şekilde bir Türk kurmay subayının İngilizlere içeriden bilgi sızdırdığı aktarılmaktadır. Bu kurmay subay, 3 Mart 1915 tarihinde filoya karşılık vermek için sadece $15 \mathrm{~cm}$ çapında toplarının olduğunu bildirdikten sonra, 5 Mart'ta daha büyük çapta topların geldiğini Ingilizlere bildirmiştir. Türk subay bilgi vermeye daha sonraki günlerde de devam etmiş ve bu sefer Boğaz'daki merkez tabyaların durumunu anlatmıştır. Daha sonra bazı top mevzilerinin yerleri ile ilgili bilgiler vermiştir. İstihbarat günlüğüne göre bu bilgiler Türk subayından aracı bir muhbir vasıtasıyla alınarak Atina'daki merkez ofise bildirilmiş, oradan da Kahire'deki İngiliz garnizonuna ulaştırılmıştır. ${ }^{55}$ Bu kurmay subayın kimliğine dair herhangi bir bilgi verilmemiştir. Yine 8 Ağustos 1915 tarihli istihbarat bülteninde ise denizci bir Türk subayının muhbire verdiği bilgilerden rapor hazırlanmıştır. Bu denizci subayın belirttiğine göre Türklerin Midilli'nin Sigir köyünde, Limni adasının Mondros civarında ve Gökçeada'da gizli sinyal ve haberleşme istasyonları vardır. ${ }^{56} 13$ Ağustos 1915 tarihli bir raporda da Sofya'dan kaçan bir Türk askeri doktorun bir Türk Albaydan aldığı bazı bilgiler verilmiştir. Yine pek çok belgede "Türk ajandan alınan bilgiye göre" ifadeleri göze çarpmaktadır. Dolayısıyla kurmay subay derecesinden başlayarak çeşitli kademelerde İngilizlere bilgi sızdıran Türk asker ve sivillerin olduğu çok açık şekilde görülmektedir.

İstihbarat raporlarının en dikkat çekici konularından biri de Çanakkale bölgesindeki Türk birliklerinin mevcudiyeti, sayısı ve

\footnotetext{
55 TNA, W.O. 157/647, General Headquarters: Intelligence Summaries, General Staff 1915 Mar. 6-July 31, 21 March 1915.

56 TNA, W.O. 157/648, General Headquarters: Intelligence Summaries, General Staff 1915 Aug., 8 August 1915.
}

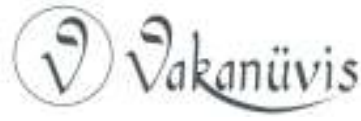


savunma hatlarına dair toplanan bilgilerdir. Tahmin edileceği üzere, bu bilgiler İngilizler açısından hayati derecede önem arz etmekteydi ve mümkün olduğu kadar gerçeğe yakın bilgiler temin edilmeliydi. Nisan 1915'te hazırlanan bir istihbarat bülteninde sadece Gelibolu Yarımadası'nda değil çeşitli bölgelerdeki Türk birlikleri ile ilgili bir tablo hazırlanmıştır:

\begin{tabular}{|c|c|c|c|c|}
\hline & $\begin{array}{l}\text { Gelibolu } \\
\text { Yarımadası }\end{array}$ & $\begin{array}{l}\text { Çanakkale } \\
\text { Anadolu Kıyıları }\end{array}$ & $\begin{array}{l}\text { Marmara } \\
\text { Denizi'nin } \\
\text { Kuzeyi }\end{array}$ & İstanbul \\
\hline $\begin{array}{l}\text { 1.Kolordu } \\
\text { İstanbul }\end{array}$ & Bir Tümen & Bir Tümen & & Yedek Kolordu \\
\hline $\begin{array}{l}\text { 2.Kolordu } \\
\text { Edirne }\end{array}$ & Bir Tümen & & $\begin{array}{l}\text { Keşan'da Yedek } \\
\text { Birlikler }\end{array}$ & \\
\hline $\begin{array}{l}\text { 3. Kolordu } \\
\text { Gelibolu }\end{array}$ & İki Tümen & \begin{tabular}{l}
\multicolumn{2}{l}{ Bir Tümen aktif } \\
Bir Tümen \\
yedek
\end{tabular} & $\begin{array}{ll}\text { Bir } & \text { Tümen } \\
\text { (Yedek) } & \end{array}$ & \\
\hline $\begin{array}{l}\text { 4. Kolordu } \\
\text { İzmir }\end{array}$ & & Üç Tümen & & \\
\hline $\begin{array}{l}\text { 5. Kolordu } \\
\text { Ankara }\end{array}$ & Bir Tümen & Bir Tümen & & \\
\hline $\begin{array}{l}\text { 6. Kolordu } \\
\text { Halep }\end{array}$ & İki Tümen & & & Bir Tümen \\
\hline Toplam & $\begin{array}{l}\text { Yedi } \\
\text { Tümen=70.000 } \\
\text { Asker }\end{array}$ & $\begin{array}{l}\text { Yedi } \\
\text { Tümen=70.000 } \\
\text { Asker }\end{array}$ & $\begin{array}{l}\text { Dört } \\
\text { Tümen=40.000 } \\
\text { Asker }\end{array}$ & $\begin{array}{l}\text { Dört } \\
\text { Tümen }=40.000 \\
\text { Asker }\end{array}$ \\
\hline
\end{tabular}

Tablo:2 Hazırlanan İstihbarat Raporlarına göre 25 Şubat-23 Mart arasında Türk Kolorduları ${ }^{57}$

Tablonun altına maddeler halinde çeşitli bilgiler de sıralanmıştır. Bu maddelerde, her bir Türk tümeninin toplam 10.000 askerden oluştuğu, Gelibolu'ya sevk edilen bütün asker, top ve mühimmatın deniz yoluyla gönderildiği ve 23 Mart itibariyle 48.000 askerin Asya yakasına, 10.000 askerin de Avrupa yakasına çıkarıldığı gibi bilgiler verilmektedir. 29. Tümen'in Nisan ayı istihbarat günlüklerine EK-1 olarak giren ve beş sayfadan oluşan bu bülten, en ayrıntılı askeri istihbarat raporlarından

57 TNA, W.O. 95/4304, 29 DIVISION, Headquarters Branches and Services: General Staff, 1915 Jan.-June, April 1915, Appendix-1.

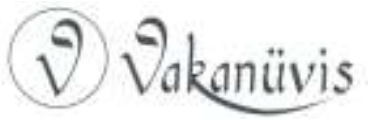


biridir ve Gelibolu Yarımadası'ndaki Türk yığınağı ile ilgili son derece önemli bilgiler içerir. Raporun üç ve dördüncü sayfalarında yarımadadaki birlikler, makineli tüfekler, toplar ve mühimmat ile ilgili rakamsal bilgiler verildikten sonra, Maydos'ta [Eceabat] 15.000 asker, 20 makineli tüfek, 4 top bataryası, Bolayır'da ise 20.000 asker olduğu rapor edilmiştir. ${ }^{58} 2$ numaralı bültende ise Çanakkale'nin Asya yakasında bulunan Türk birlikleri, siperler, yollar ve toplar hakkında bilgi verilmiştir. Bunun yanı sıra Çanakkale'ye yakın olması sebebiyle birlik sevk edilebilecek yerler olan Edremit Körfezi ve İzmir bölgesindeki kuvvetler ile ilgili de bilgiler rapora girmiştir. ${ }^{59}$

Çanakkale'deki Türk savunması ile ilgili en önemli raporlardan biri de 1 Nisan 1915 tarihli dört numaralı istihbarat bültenidir. İki sayfadan oluşan bu bültende 10 başlık altında Türk savunması incelenmiştir. Örneğin, "Türk Askerleri" konulu başlıkta Gelibolu Yarımadası'na konuşlandırılan toplam asker sayısı, 80.000 olarak verildikten sonra, bunların Türk ordusundaki en seçme askerler oldukları, Almanlar tarafından eğitildikleri, mavzer tüfekleriyle donatıldığı ve ordu içinde 6.000 Alman olduğu belirtilmiştir.

Raporlara bakıldığında (özellikle 1 Nisan tarihli rapor) asker sayısının gerçekte olanın yaklaşık iki katı olarak hesaplandığını görmekteyiz. 18 Mart'ta İtilaf Devletleri filosunun Çanakkale Boğazı'nı geçememesi sonrasında muhtemel kara çıkarmaları için hazırlık yapan Başkumandanlık Karargâhı, merkezi Gelibolu'da olmak üzere 5. Ordu Komutanlığının kurulmasına karar vermiştir. 5. Ordu Komutanı olarak atanan Liman von Sanders, bölgeye geldikten sonra bütün savunma tertibatını değiştirmiş, kafasındaki plan doğrultusunda Gelibolu Yarımadası'nın savunmasını 3. Kolordu Komutanlığına vermiştir. Bu kolordunun komutanı ise Esat Paşa'dır. 3. Kolordu, 9. Tümen, 19. Tümen, 7. Tümen ile birlikte Bursa Seyyar Jandarma Taburu, Gelibolu Seyyar Jandarma Taburu, Kolordu Süvari Bölüğü ve Bolayır Ağır Topçu Taburundan oluşturulmuştur. ${ }^{60}$ Dolayısıyla 3 . Kolordunun Nisan ayı

58 TNA, W.O. 95/4304, 29 DIVISION, Headquarters Branches and Services: General Staff, 1915 Jan.-June, April 1915, Appendix-1.

59 TNA, W.O. 95/4304, 29 DIVISION, Headquarters Branches and Services: General Staff, 1915 Jan.-June, April 1915, Appendix-2.

${ }^{60}$ Birinci Dünya Savaşı'nda Çanakkale Cephesi, C.V, Kitap I, Ankara 2012, s.203-204.

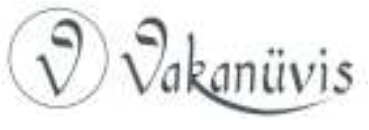


başında toplam muharip asker sayısı İngilizlerin tespit ettiği gibi 80.000 asker değil, bunun yarısı kadar kuvvete denk gelmektedir. 25 Nisan çıkarmalarına gelindiğinde ise Türk ordusu kuzeyde Saroz'dan güneyde Anadolu tarafında Beşigelere kadar $150 \mathrm{~km}$ kıyı şeridini toplam altı tümenle savunmaya çalışmıştır (Gelibolu'da toplam dört tümen). ${ }^{61}$ Yani 1 Nisan tarihli istihbarat bülteninde belirtildiğinin aksine, Gelibolu Yarımadası'nda değil 1 Nisan, çıkarmalar başladıktan sonra Mayıs başına kadar bile 80.000 Türk askeri olmamıştır.

Raporun devamında Gelibolu'da konuşlanan Türk ordusunun yapısı, kullanılan askeri teçhizat ve yedek kuvvetlerle ilgili de istihbarat çalışması yapılmış ve bunlar başıılar halinde verilmiştir. Buna göre Türk ordusundaki tümenlerin bütün sınıflar dahil toplam mevcudu 10.000 kişi olarak saptanmıştır. Bu doğru saptamanın yanında "Makineli Tüfekler" başlığı altında Çanakkale'deki Türk alaylarında en fazla dört adet makineli tüfek vardır denmiştir ki bu da kesinlikle doğru bir bilgidir. Alman Askeri Islah Heyetinin ülkeye gelmesinden sonra 1914 yılında ordunun yeniden organize edilmesi esnasında her piyade alayının üçer taburdan, taburların ise dört bölükten oluşmasına karar verilmiş ve her alaya dörder tüfekli bir makineli tüfek bölüğü verilmesi esas alınmıştır. ${ }^{62}$ "Topçular" başlı̆̆ında ise bölgenin Alman toplarıyla korunduğu belirtilmiştir. Verilen bilgiye göre bölgede 46 Alman Howitzer topu bulunmaktadır fakat bunların en fazla 10 tanesi 5.9 kalibreliktir. Raporda topların kalibrelerinin düşük olduğu ifade edilmiştir. Bu anlamda bölgede bulunan topların yaklaşık on adedinin 5.9 kalibrelik olduğuna dikkat çekilmiştir. Başlığın sonunda Gelibolu'da top cephanesinin az olduğu da özellikle vurgulanmıştır. Şunu belirtmek gerekir ki Çanakkale Muharebeleri boyunca piyade cephanesi ülke içindeki askeri fabrikalardan rahatlıkla temin edilirken, topçu cephanesinin ikmali her daim büyük bir sorun olmuştur. ${ }^{63} \mathrm{Bu}$ sebeple özellikle muharebelerin yoğunlaştığı günlerde Türk topçusu yaşanan mühimmat sıkıntısından dolayı düşmana yeterince karşılık verememiştir.

\footnotetext{
61 a.g.e, c.ll, s.7.

62 Türk Silahlı Kuvvetleri Tarihi (1908-1920), s. 221.

${ }^{63}$ Birinci Dünya Savaşı'nda Çanakkale Cephesi, C.I, s.242.
}

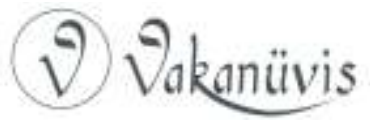


Türk ordusunun mevcudiyeti ve yapısı hakkında verilen çeşitli bilgilerin yanında Gelibolu Yarımadası üzerindeki yolların durumu, ulaştırma imkânları, su kaynakları ve bölgede yaşayan halkın durumu ile ilgili de bilgiler sıralanmıştır. Bölgedeki yolların durumu hakkında Ingilizler önemle durmuş ve bilgi toplamaya çalışmıştır. Bunun sebebi, ordunun karaya çıkmasının akabinde ağıllıklarıyla süratli şekilde hangi yollardan ne derece hızlı yürüyebileceği sorusudur. Kendi tespitlerine göre yarımadada mevcut yollar kırmızı kildir ve ıslak-yağışı havalarda son derece yumuşak ve vıcık hale gelmektedir. Yağmur sezonunun 15 Nisan civarlarında bittiği tespit edilmiştir. Yollar son zamanlarda geliştirilerek bazı kısımları beton ile yapılmıştır. Savaş başlamadan önce Maydos-Kirte yolunda 5.000 işçi çalıştıılarak iki at arabasının geçeceği genişlikte yapıldığı gözlemlenmiştir. Ulaştırma imkânlarının son derece kısıtlı olduğu belirtildikten sonra ulaşım aracı olarak kağnılar, eşekler ve develerin kullanıldığı bilgisi verilmektedir.

Gelibolu'daki yolların ve ulaşım imkânlarının son derece kısıtlı olması Türk komutanlarını da düşündürmekteydi. İstanbul veya diğer merkezlerden Çanakkale'ye ana ulaşım ve ikmal yolu deniz yolu olsa da (raporda belirtildiği gibi) Gelibolu Yarımadası'nda bir noktadan başka bir noktaya kuvvet kaydırmak için kara yolu kullanılmaktaydı ve yollar büyük ölçüde yetersizdi. 25 Nisan çıkarmalarından önce bir takım iyileştirmeler yapılsa da karadan ulaşım daima sınırlı ölçüde ve zorlukla sağlandı. ${ }^{64}$ Nitekim Liman von Sanders göreve geldikten sonra yol ve ulaştırma konusunda karşı karşıya kaldığı sorunları anılarında anlatmaktadır: "Yarımadayı boydan boya kat eden yollar hemen hiç yoktu. Ekseriyetle yük hayvanlarının tekli koldan geçebileceği patikalar ve keçi yolları vardı ama buralardan sahra topçusu bile geçemezdi." ${ }^{\prime 65}$

Eldeki imkânlar çerçevesinde bir takım çalışmalar yapıldı fakat yol ve ulaşım konusunda savaş boyunca istenilen gelişme sağlanamadı. Nakliye olanakları ihtiyacı karşılamaktan o kadar uzaktı ki askerler bir noktadan bir noktaya intikal ederken çok uzun ve yorucu yürüyüşler yapmak zorunda kalıyordu. 25 Nisan çıkarmalarında son derece kritik saatler yaşanırken, mevcut yolların ve eldeki ulaşım araçlarının yetersizliği sebebiyle 33. Alay 24 saatte; 64. Alay ise tam 30 saatte

\footnotetext{
64 a.g.e, s. 243.

${ }^{65}$ Liman von Sanders, Türkiye'de Beş Yıl, Çev: Eşref Bengi Özbilen, İstanbul 2018, s.91.
}

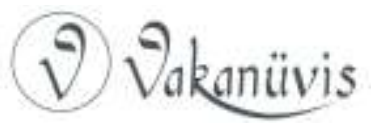


Arıburnu'na yetişebilmişti. ${ }^{66} 6$ Ağustos Anafartalar çıkarmasında da Bolayır-Saroz bölgesinden Anafartalar'a intikal eden birlikler cephede son derece kritik dakikalar yaşanırken, herhangi bir ulaşım aracı olmadığı için 40 kilometrelik yolu yürüyerek aşmaya çalışmış ve yüzlerce asker bu zorlu yürüyüşte yollarda kalmıştır. ${ }^{67}$ Genç subaylardan İsmail Hakkı, bu zorlu yürüyüşü anılarında ayrıntılarıyla anlatmaktadır: "Asker uzun yol yürüdüğünden ve yeter derecede uyuyamadığından çabuk yoruluyor. Sürüklenir gibi gidiyorlar. Gittikçe mevcudumuz eksiliyor. Yürüyüş intizamı bozulmuş, adeta silahını kapan cepheye koşuyormuş gibi başıbozuk bir hal almıştı." dedikten sonra alayın dörtte üçünden fazlasının yollarda kaldığını belirtmektedir. ${ }^{68}$

Yollar ve ulaşım başlıklarından sonra yarımadada bulunan su kaynakları irdelenmiş ve köylerdeki su kuyuları ile derelerin durumu hakkında bilgiler verilmiştir. Bir diğer başık ise bölgede yaşayan yerel halkla ilgilidir. İstihbarata göre bölgedeki köylerde yaşayan Rumlar zorla göç ettirilerek bunların yerine bazı köylere Müslüman halk yerleştirilmiştir. Yarımadanın en güneyindeki köyler ise tamamen boşaltılmış durumdadır. İstihbarat bülteninin sonundaki tespit ise ilginçtir: "Eğer şu an bu köylerde birileri varsa bunlar Almanlar hesabına çalışan casuslardır" ${ }^{69}$ denmektedir.

İlk 9 madde özetle bu şekilde sıralandıktan sonra onuncu maddede "Türk savunması" başlığı altında çarpıcı tespitler yapılmıştır. İlk cümlede şöyle denmektedir: "Türklerin saldırımızı Bolayır berzahından beklediği çok açık. Çıkarmayı karşılamak için bütün hazırlıklarını buna göre yapmışlar" İngilizlerin yaptığı gözlemler ve aldığı istihbarat bilgilerine göre Türklerin Gelibolu Yarımadası'ndaki savunma ağırlığının Bolayır-Saros bölgesi olduğunu net şekilde tespit ettikleri görülmektedir. Bu noktada Türk savunma tertibatı üzerinde kısaca durmakta fayda var.

\footnotetext{
66 Kıbıl, a.g.e, s.133.

67 a.g.e, s.307.

68 İsmail Hakkı Sunata, Gelibolu'dan Kafkaslara Birinci Dünya Savaşı Anılarım, Haz.: Kansu Şarman, İstanbul 2003, s.127.

69 TNA, W.O. 95/4304, 29 DIVISION, Headquarters Branches and Services: General Staff, 1915 Jan.-June, April 1915, Appendix-4.
}

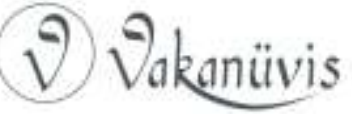


5. Ordu Komutanı Liman von Sanders, bölgeye gelip komutayı ele aldıktan sonra Türk komutanların aldığı savunma tertibatını tamamen değiştirerek yarımadada bulunan dört tümenden ikisini (5. ve 7 . Tümenler) Saroz-Bolayır'a konuşlandırmıştır. Diğer iki tümenden biri ihtiyat kuvveti olarak (19.Tümen) geriye Bigalı Köyü’ne, diğeri ise (9. Tümen) Arıburnu'ndan Seddülbahir'e kadar son derece geniş bir bölgeyi savunması için yarımadanın en güneyine yerleştirilmiştir. ${ }^{70}$ Yani Türk savunmasının kuvvet ağırlığı İngilizlerin de doğru şekilde tespit ettiği gibi Bolayır bölgesindedir. Ayrıca Liman von Sanders gelmeden önce Türk komutanların uyguladığı savunma prensibi, yani kıyıların kuvvetli birliklerle tutularak düşmanı karaya çıkarken imha etme anlayışı terk edilmiş, yeni plan gereği kıyılar zayıf tutularak geride güçlü intiyatlar bulundurma prensibine geçilmiştir. Nitekim bu hatalı savunma dizilişi sebebiyle 25 Nisan'da Arıburnu ve Seddülbahir'de çıkarmaları karşılayan her Türk birliği karşısındaki düşmana oranla sayısal olarak oldukça zayıf kalmış ve son derece buhranlı saatler yaşanmıştır. Dolayısıyla şu tespiti kolayca yapabiliriz; 25 Nisan sabahı İngilizler, Türk savunmasının nerelerde güçlü nerelerde zayıf olduğunu önceden bilmekteydiler. İstihbarat raporlarına göre, çıkarma başlamadan önce en kritik unsur olan Türk savunma tertibatını doğru şekilde tespit etmiş olan İngilizler, ellerindeki taktik üstünlüğü muharebeler başladıktan sonra avantaja çevirmemiş ve başarısız olmuşlardır.

Raporun on birinci ve son maddesinde ise "Mukavemet" başlığında Türk ordusundan beklenen direniş şu cümlelerle aktarılmıştır:

"Genel görüşe göre Türkler saldırımıza enerjik bir direnişle karşı koyacaklar. Ama yarımadaya sağlam olarak yerleştiğimizde bu direnişin çözüleceği ve Alman efendilerinin aleyhine dönebilecekleri düşünülmektedir. Ortalama Türk, Ingiliz milletine her zaman sempati duymuştur ve çoğunun Mısır'ın Britanya yönetimi altında sahip olduğu refaha kıskançıkla baktığı bilinmektedir"

Liman von Sanders, çıkarmayı Bolayır bölgesinde beklese de Ingilizlerin planı bu değildi. Akdeniz Seferi Kuvvetler Komutanı lan Hamilton'ın ana hedefi en kestirme yoldan Boğaz'a ulaşmaktı ve bu hedef için en önemli noktanın Kilitbahir Platosu yani yarımadanın

${ }^{70}$ Birinci Dünya Savaşı'nda Çanakkale Cephesi, C.II, s.7-8.

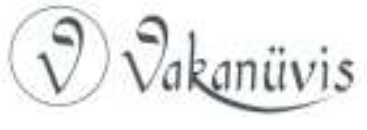


güneyi olduğunu kavramıştı. Bunun için donanmanın ezici ateş gücüne de güveniyordu. ${ }^{71}$ Yani çıkarmanın her aşamasında donanmanın desteği hayati öneme sahipti. "Seddülbahir'e çıkarma Olanakları" başlığında bu bölgenin Alçıtepe'ye kadar denizden rahatlıkla görülebildiği, hem dost hem düşman birliklerin her hareketinin gözlemlenebileceği belirtilmiştir. Seddülbahir hem Boğaz'ın en dar yerine yakındı hem de gerekli donanma desteğini sağlamak için avantajlı bir konuma sahipti. Dolayısıyla çıkarma yapılması planlanan sahillerle ilgili ayrıntılı gözlem ve istihbarat çalışmalarına ihtiyaç vardı. 14 Nisan'da Arıburnu ve Seddülbahir arasındaki kilit bölgelerde havadan ve denizden keşif çalışmaları yapıldı. Kapsamlı bir hava keşfi yapılamadığı için, son çare olarak denizden yapılacak gözlem çok önem kazanmıştı. ${ }^{72}$ Denizden yapılan gözleme 29. Tümen Komutanı General Hunter-Weston, kurmayları ve Anzak karargâhından bazı subaylar da katıldılar. 29. Tümen savaş günlüğünde bu gözlem sırasında yaşananlar şöyle aktarılmıştır:

"Gemi Tekke Burnu, Seddülbahir ve Morto Koyu Eski Hisarlık burnuna kadar dolaştı. Bu esnada hiç düşman askeri görülmedi. Alçıtepe'nin kuzey çıkıntısı, Kirte ve daha güneyindeki bazı kamplardan duman yükseliyordu. Yarımadanın güney ucunda yoğun siper ve engeller gözlemlendi. Bu siper ve engeller özellikle Karacaoğlan Tepesi, Aytepe ve Harapkaletepe civarında yoğunlaşmıştı"73

14 Nisan'da yapılan gözlemler Anzak Kolordusunun savaş günlüğüne ise şöyle not edilmiştir:

"Queen Bolayır'dan aşağı doğru Ece Limanı'ndan yakın geçerek Seddülbahir'e indi. Kabatepe kuzeyindeki çıkarma noktaları dikkatlice incelendi. Düşman siperleri ve top mevzileri tespit edildi. Edinilen bilgiler Queen'deki istihbarat subayından alınan bilgiler ile de bağdaştırıldı. Bu esnada hiç adam [Türk] görülmedi ve görünüşe göre karada hiçbir faaliyet yoktu. Seçilen sahil mükemmel gözüküyordu. Ele

\footnotetext{
71 Kıbıl, a.g.e, s.18.

72 Chasseaud-Doyle, a.g.e., s.126-127.

73 TNA, W.O. 95/4304, 29 DIVISION, Headquarters Branches and Services: General Staff, 1915 Jan.-June, 14 April 1915.
}

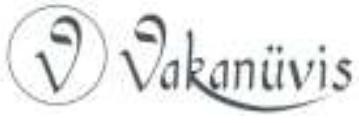


geçirmemiz gereken ve öncelikli hedefimiz olan asıl büyük tepenin (Sarıbayır) sırtları tespit edildi. Bu sürede hiç ateş edilmedi"74

18 Nisan'da 29. Tümen kurmayları Seddülbahir'de denizden bir kez daha keşif yaptılar. Denizden yapılan bu keşif çalışmaları yapılacak çıkarma için paha biçilemez derecede önemliydi. Daha sonra gelen hava gözlem raporlarıyla bilgiler birleştirilecekti. 20 Nisan'da Türk savunma hatlarını gösteren son harita güncellenerek basılı hale getirildi. Haritada, Türk ateş siperleri, irtibat siperleri (zik-zak olarak yapılan) top hendekleri ve kaç adet top olduğu, yürüyüş yolları, tabyalar kısaca sahilleri çevreleyen tepelerden Alçıtepe'ye kadar her türlü savunma unsuru gösterilmekteydi. ${ }^{75}$

14 Nisan'da Seddülbahir, 18 Nisan'da Arıburnu'ndaki Türk savunması yapılan gözlemlere dayalı olarak ve hava fotoğrafları ile desteklenerek harita olarak basıldı. ${ }^{76}$ Genel karargâh tarafından hazırlanan bu haritalar, hava fotoğrafları ile sı aralıklarla güncellenerek İngilizlere önemli taktik istihbarat sağlamıştır. Havadan çekilen fotoğraflar o dönemde çok yeni kullanılmaya başlandığı için bu fotoğraflar ilk başta sadece genel karargâhta değerlendiriliyordu fakat savaşın ilerleyen dönemlerinde 29. Tümen gibi daha alt birliklere de Türk savunma pozisyonlarını gösteren fotoğraflar verilmiştir. İngilizler havadan yapılan keşif çalışmalarına gün geçtikçe daha çok önem vererek hava fotoğrafları çekme konusunda ustalaşmışlar ve bu gözlemleri istihbarat raporlarına daha çok girmeye başlamıştır.

Yine çıkarmalar başlamadan önce "Gelibolu Yarımadası Kabatepe ve Seddülbahir Arası Çıkarma Olanakları"77 başlıklı altı sayfa ve 16 maddeden oluşan istihbarat raporu ile "Gelibolu Yarımadası'nın Batı Kısmında Kabatepe'den Bolayır Hattına Çıkarma Olanakları ve Diğer

\footnotetext{
74 TNA, W.O. 95/4280, 1 ANZAC, Headquarters Branches and Services: General Staff 1915 Feb.-May, 14 April 1915.

75 TNA, W.O. 157/668, Anzac Corps: Intelligence Summaries, April 1915., W.O. 157/678, New Zealand and Australia Division: Intelligence Summaries, April 1915.

76 TNA, W.O. 301/499, Gallipoli Peninsula: Sketch plan showing results of Air Reconnaissance to 14 Apr 1915. W.O. 301/500, Gallipoli Peninsula: Sketch plan showing results of Air Reconnaissance to 18 April 1915.

77 TNA, W.O. 95/4304, 29 DIVISION, Headquarters Branches and Services: General Staff, 1915 Jan.-June, April 1915, Appendix-6.
}

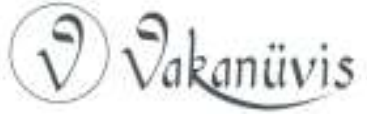


önemli Unsurlar"178 başlıklı üç sayfadan oluşan toplam dokuz sayfalık ayrıntılı raporlar hazırlanmıştır. Bu iki raporda arazi ve kıyı şeridi hakkında genel görüşler ve açıklamalar, karaya çıkacak birlikleri koruyacak gemilerin alması gereken pozisyonlar için tavsiyeler ve süvari ile topçuların nasıl kullanılacağına dair fikirler öne çıkmıştır. 25 Nisan 1915'te çıkacakları sahiller için yaptıkları istihbarat çalışmaları bu raporlarda daha ayrıntılı görülmektedir. Hiçbir ayrıntı gözden kaçırılmamaya çalışı Imıştır.

Sonuç olarak, her ne kadar Akdeniz Seferi Kuvvetleri Komutanı lan Hamilton'ın önünde çıkarma hazırlıkları için çok fazla süre olmasa da, savaştan sonra şikâyet etmesinin aksine, Gelibolu Yarımadası'nın coğrafi özellikleri, Türk savunma tertibatı ve Türk ordusunun durumu hakkında kısa sürede gerçekten faydalı istihbarat bilgileri toplanmış ve bunlar raporlanarak kendisine sunulmuştur. Yine Hamilton'ın belirttiğinin aksine, bölgenin haritaları da kendisinde ve karargâhında mevcuttur. ${ }^{79} 25$ Nisan çıkarmalarından önce Yarımada'nın güneyinde uçaklar ile çok sayıda başarılı gözlem ve keşif uçuşu gerçekleştirilmiş, kritik bölgeler ve Türk savunmasına dair her şey listelenerek bütün birliklerin karargâhlarına gönderilmiştir. 29. Tümen, Kraliyet Deniz Tümeni ve Anzak Kolordusuna Türk savunmalarının nerede bulunduğuna dair haritalar grafikler ile desteklenerek basılı olarak verilmiştir. Bu birliklerin harp günlüklerinde onlarca hava istihbarat raporu ve haritası vardır. ${ }^{80}$

\section{Muharebeler Başladıktan Sonra Yapılan İstihbarat Çalışmaları}

25 Nisan çıkarmalarından sonra muharebeler devam edip savaş uzadıkça istihbarat raporlarının içeriğinin de değiştiği görülmektedir. Mayıs ayından itibaren hazırlanan raporlar daha çok Türk savunmasının niteliği, hangi birliklerin yarımadanın neresinde konuşlandığı, Türk ordusunun moral-motivasyonu ve cephede gelişen günlük hadiselerle ile ilgilidir. Her tümen cephesindeki Türklerle ilgili hadiseleri günlük olarak "Hareketler-Işler-Genel" başlıkları altında

\footnotetext{
78 TNA, W.O. 95/4304, 29 DIVISION, Headquarters Branches and Services: General Staff, 1915 Jan.-June, April 1915, Appendix-7.

${ }^{79}$ Gelibolu'da kullanılan haritaların ayrıntılarına bakmak için bknz: TNA, W.O. /153., TNA, W.O. /301.

80 Hugh Dolan, Gallipoli Air War, Sydney 2013, s.60-61.
}

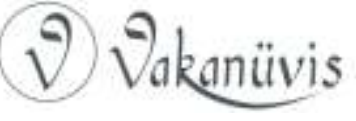


raporlayarak bağlı olduğu kolordu komutanlığına göndermiş ve gelen bu bilgiler kolordu tarafından günlük istihbarat özeti olarak raporlanmıştır.

Mesela, 29. Tümenin 19 Mayıs 1915 tarihli istihbarat bülteninde Çanakkale'deki Türk askerlerinin bitkin ve tükenmekte olduğu ve yerlerine taze kuvvetler gelmedikçe hatlarını tutamayacakları söylendikten sonra, bölgeye İstanbul, Edirne ve Suriye'den takviyeler getirildiği belirtilmiştir. Bu raporun ardından "Yarımadanın güney kesimindeki Türk kuvvetlerinin moral vb. ile ilgili genel notlar (düşmanla temas eden birimlerden elde edilen)" başlığıyla verilen ve 6 maddeden oluşan bir başka rapor daha hazırlanmıştır. Bu maddelerde özet olarak, genel kanıya göre Türklerin çok iyi savaştığı ve morallerinin iyi olduğu, ellerinde çok miktarda makineli tüfek bulunduğu ve bunları iyi kullandıkları, çok iyi keskin nişancıları olduğu ve Türkler temiz savaşsa da Almanların savaş hilelerini Türklere öğrettikleri belirtilmiştir. ${ }^{81}$ Tarihi belirtilmemiş fakat Haziran ayında hazırlanmış bir başka raporda; "Türk Ordusunun Pozisyonu ve Savaş Hakkında Düşünceleri" başlığı altında 5 maddede enteresan tespitler yapılmıştır. Rapora kaynak olarak esir alınan Türklerden elde edilen bilgiler ve diğer güvenilir kaynaklar gösterilmiştir. Tespitlerin bazıları şöyledir:

"Artık daha net görülüyor ki Türk ordusu savaştan bıkmış durumdadır. Eğer güven içinde teslim olmaları sağlanabilirse çok geniş sayıda kişi bunu yapabilir. Bunun birkaç sebebi var: Zayiat sayısı oldukça fazla boyutta. Gelen takviyeler daha çok evine bir an önce dönmek isteyen köylüler. Türk askerleri büyük yokluk ve zorluklara katlanmakta. Levazım kötü. Ele geçirilen belgeler gösteriyor ki, Tabur komutanları, levazım subaylarının pek çok kez yeterli verim sağlamadaki başarısızlığı nedeniyle mahkemede yargılanması talebinde bulundular. Türklerin 3 yıl içinde bu üçüncü savaşı. Ayrıca, bu son savaşı Almanların başlatmasının yanında, kazanılsa bile Türkiye'ye faydasının ne olacağı bilinmediği için ve Türklerin çoğu Ingiltere'yi en iyi dost olarak bildikleri için bu savaşı gereksiz görüyorlar."

81 TNA, W.O. 95/4304, 29 DIVISION, Headquarters Branches and Services: General Staff, 1915 Jan.-June, 19 May 1915.

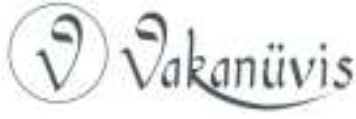


Türk askerlerinin hangi zorluklarla mücadele ettiği sıralanıp moralinin iyi olmadığı belirtildikten sonra Türk ordusunun nasıl hala iyi savaştığı ile ilgili tespitler ise şu şekildedir:

"Peki, Türklerin savaşma azmi gerçekten kırıldıysa neden hala iyi savaşıyorlar? Bunun cevabı gayet basit: Askerler ya savaşacaklar ya da kendi makineli tüfekleri tarafindan arkadan vurulacaklar. Türklerle savaşan Almanlar, yüzbaşı rütbesine kadar olan askerler üzerinde yaşatma ve öldürme gücüne sahip. Gerçekte Türk askerleri iki arada bir derede kalmış olarak savaşmakta. Şu ana kadar ele geçirilen esirlerin ifadelerine göre biraz daha ilerleyebilirsek Türkleri kaçarken görebiliriz. Türk, doğası gereği işler iyi gittiğinde siperde dönüşümlü olarak sigara içmekten ve ateş etmekten memnundur ama gerçekten korkar ve kaçarsa, kendi makineli tüfeklerinin tehdidini bile unutur. Hatırlasa bile risk alıp kaçar. Eğer bir kez kuyruğu aşağı inerse, tekrar kalkması uzun zaman alacaktır. Bütün belirtiler son bir iyi vuruşla Türkleri yere sereceğimizi göstermektedir." ${ }^{12}$

Bu raporlar İngilizlerin Türkler hakkında düşüncelerini göstermesi bakımından önemlidir. Savaş süresince Türk askerleri ile ilgili bu ve buna benzer pek çok rapor hazırlandığı görülmektedir. Cephe ile ilgili raporlarda dikkat çeken bir başka nokta, cereyan eden taarruzlar sonrası Türk kayıplarıyla alakalıdır. Hemen her taarruz sonrası tahmini Türk zayiatı listelenmiştir.

Yapılan keşif ve gözlemler ile Türk birliklerinin hareketleri yakından takip edilmiştir. Anzak Kolordusu Komutanı General Birdwood, 20 Mayıs 1915 tarihli raporunda, Türklerin 19 Mayıs 1915'te yaptığı taarruzdan önce havadan ve denizden yapılan keşif ve istihbarat çalışmalarından bahsetmektedir. Bu keşif çalışmaları sayesinde Türklerin Arıburnu'na büyük miktarda asker yığdığı istihbaratının alındığını belirtmiştir. Gelen bu istihbarat bilgilerinden sonra bütün Anzak askerlerinin alarma geçirildiğini ve Türk saldırısının başarılı şekilde az zayiatla püskürtüldüğünü, Türklerin en az 30.000 askerle taarruza kalktığını ve en az 3.000 tanesinin ölü olarak ara bölgede yattığının tespit edildiğini aktarır. ${ }^{83}$ İngiliz resmi tarihi, uçaklarla yapılan

82 TNA, W.O. 95/4304, 29 DIVISION, Headquarters Branches and Services: General Staff, 1915 Jan.-June, Tarih belirtilmemiş.

83 TNA, W.O. 95/4280, 1 ANZAC, Headquarters Branches and Services: General Staff 1915 Feb.-May, May 1915, Appendix-37.

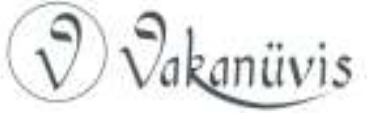


keşif sayesinde Arıburnu doğusunda büyük Türk birliklerinin toplandığını ve Akbaş Limanı'na önemli kuvvetlerin çıkarıldığının bilindiğini belirtmektedir. ${ }^{84} 18$ Mayıs'ta Anzak karargâhına gönderilen bir hava gözlem raporunda da kıyıya çok sayıda deniz taşııının yanaşarak yaklaşık bir tümen boyutunda asker çıkardığı ve gece taarruzuna karşı birliklerin alarma geçirilmesi gerektiği bildirilmiştir. ${ }^{85}$ Gerçekten de 11Mayıs'ta İstanbul'dan gemilerle Çanakkale'ye doğru yola çıkarılan 2. Tümen, yıpranmamıs ve tam mevcutlu olarak 14 Mayıs'ta Akbaş Limanı'na çıkarılmış ve buradan yaya olarak Arıburnu doğusundaki sırtlara yanaştırılmıştır. ${ }^{86}$

Görüldüğü gibi bütün savaş boyunca Arıburnu'nda gerçekleştirilen en büyük Türk taarruzu olan ve 42.000 askerin katıldığı 19 Mayıs taarruzu, düşmanın yaptığı gözlem ve istihbarat çalışmaları sayesinde önceden sezilmiş ve buna karşı hazırlık yapılmıştır. Akşam saat 22.30'da bütün Anzak kolordusu alarma geçirilerek Türk taarruzu beklenmeye başlamıştır ve sabaha karşı 03.00'ten sonra taarruz başlamıştır. Kötü planlanan ve kötü yönetilen 19 Mayıs taarruzunda Türk birlikleri birkaç saat içinde son derece dar bir arazide 10.000 zayiat vermiştir. General Birdwood'un tespit ettiği gibi bunun 3.000 tanesi şehittir. Taze kuvvet olarak İstanbul'dan getirilen 2. Tümenin zayiatı korkunçtur. 03.00'te başlayan taarruz sonrası saatler 05.20'yi gösterdiğinde tümenin taarruz gücü tamamen kırılmış ve henüz gün doğmadan iki saat içinde tümenin yarısı zayiat verilmiştir. ${ }^{87}$ Buna karşılık Anzak zayiatı, 160 ölü 468 yaralı olmak üzere toplam 628 kişidir. ${ }^{88}$ Türk ordusu bu felaketten sonra Arıburnu'nda savaşın sonuna kadar bir daha büyük çapta bir taarruza kalkmamış ve savunmada kalmıştır. Doğru şekilde yapılan istihbarat ve gözlem çalışmalarının önemi bu acı hadisede net olarak anlaşılmaktadır.

Diğer yandan bazı Türk komutanlar hakkında çeşitli bilgiler de raporlanmıştır. Örneğin, daha önce Esat Paşa ile teması olan bir

\footnotetext{
${ }^{84}$ Aspinall Oglander, Büyük Harbin Tarihi Gelibolu Askeri Harekâtı, Haz.: Metin Martı, İstanbul 2005, C.II, s.28.

85 TNA, W.O. 95/4280, 1 ANZAC, Headquarters Branches and Services: General Staff 1915 Feb.-May, May 1915, Appendix-36.

${ }^{86}$ Birinci Dünya Savaşı'nda Çanakkale Cephesi, C.II, s.119.

87 Kıbıl, a.g.e, 191.

88 a.g.e, s.196-197.
}

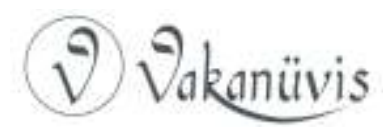


gazetecinin aktardıklarına dayanarak Kuzey Grubu Komutanı (Arıburnu) Esat Paşa ile ilgili bir rapor hazırlanmıştır. Bu rapordaki ifadelerin bir kısmı şöyledir:

“3. Kolordu Komutanı olan Esat Paşa, Yanya'nın eski ailelerinden birine mensuptur ve diğer bölge Müslümanları gibi iyi Yunanca bilir. İyi eğitimlidir. Fransızca ve Almancayı akıcı konuşur. Aktif, iyi görünüşlü, saygıdeğer en iyi Türk subayı tipidir. Balkan Savaşı sırasında Yanya'yı Yunanlılara karşı aylarca savunmuş, bütün imkânlar tükenince teslim olmuştur. Atina'da bir müddet esir kaldıktan sonra kolordu komutanlığına atanmış ve Enver Paşa Savaş Bakanı olduktan sonra görevinde kalmayı başarmış birkaç generalden biridir. Politikayı sevmez ama kardeşi Vehip, ittihat ve Terakki'nin aktif elemanlarından biridir" ${ }^{\prime \prime 9}$

İngilizler, Çanakkale'deki istihbarat çalışmaları dahilinde muharebenin çeşitli aşamalarında oldukça fazla sayıda Türk birliğinin operasyon emirlerini de ele geçirmişlerdir. 9. Tümen Komutanı Albay Halil Sami Bey'in 7 Nisan 1915 tarihli tümen emri, 19. Tümen Komutanı Yarbay Mustafa Kemal Bey'in 23 Mart tarihli tümen emri, 26. Alay Komutanı Yarbay Hafız Kadri Bey'in 25 Nisan çıkarma günü verdiği emirler gibi çok sayıda Türk operasyon emirleri istihbarat bültenlerine girmiştir. ${ }^{90}$

Diğer yandan şehit olan veya esir düşen Türk komutanların günlükleri de faydalı bilgiler içerdiği için istihbarat raporlarında yer bulmuştur. Bunlardan en dikkat çekeni Arıburnu'nda 28 Nisan günü göğsüne isabet eden bir kurşunla şehit olan 33. Alay komutanı Yarbay Ahmet Şevki Bey'in yerine tayin edilen 1. Tabur komutanı Binbaşı Faik Bey'in günlügüudür. Faik Bey, 28 Nisan'da alay komutanlığını devraldıktan 2 gün sonra kendisi de şehit olmuş ve anlaşılan o ki cesedi ilk önce Avustralyalılar tarafından bulunduktan sonra üstü aranmış ve günlüğü alınmıştır. Siper hatlarının tam oturmadığı, karşılıklı dalgalanmaların yaşandığı bu ilk günlerde, Avustralyalılar muhtemelen cesedi gömecek kadar zaman bulamamış ve daha sonra bölgeye gelen Türkler cesedi bulup Eceabat yakınlarındaki Balkan Savaşı Mezarlığına

\footnotetext{
89 TNA, W.O. 95/4304, 29 DIVISION, Headquarters Branches and Services: General Staff, 1915 Jan.-June, May 1915, Appendix-14.

90 TNA, W.O. 95/4304, 29 DIVISION, Headquarters Branches and Services: General Staff, 1915 Jan.-June, 26 May 1915.
}

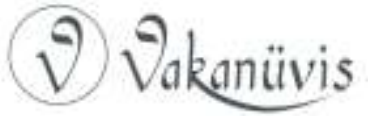


gömmüşlerdir. Faik Bey'in günlüğü 30 Nisan'a kadar Arıburnu muharebeleri hakkında önemli bilgiler içerir. Bu günlükten elde edilen bilgiler analiz edilerek istihbarat bültenine girmiştir. Bugün bu günlük, içinde tümen emirleri ve bazı krokiler olduğu halde 29. Tümen istihbarat raporlarında görülmektedir. ${ }^{91}$ Bunun yanında bir diğer dikkat çekici günlük, 16. Tümen 47. Alay'dan ismi belirtilmeyen bir subayın günlüğüdür. 6 Ağustos'ta Kanlısırt'ta ele geçirilen bir Türk siperinin içinde bulunmuş ve bu günlük İngilizceye çevrilerek raporlanmıştır. ${ }^{92}$

\section{İstihbarat Raporlarında Propaganda Unsuru}

İstihbarat bültenlerine konu olan bir başka önemli unsur da iki taraf askerlerinin özellikle siperlerin yakın olduğu bölgelerde birbirlerine propaganda amaçlı attığı bildiriler ve mektuplardır. I. Dünya Savaşı'nın bütün cephelerinde savaşan ordular propaganda silahını yoğun şekilde kullanmıştır. Bundaki amaç karşıdaki ordunun savunma ve taarruz gücünü zayıflatarak muharebeden vazgeçirmeye çalışmaktır. ${ }^{93}$

İngilizler, muharebe ettikleri ülkelere karşı etkili bir propaganda yürütmek için 2 Eylül 1914'te Wellington House'da özel bir Savaş Propaganda Bürosu (War Propaganda Bureau) kurmuşlardır. ${ }^{94}$ Psikolojik harbin en temel unsurlarından olan beyannameler ise propaganda bu şubeleri tarafından hazırlanmış ve çok sayıda bastırılmıştır. Beyannameler, çok farklı şekillerde ve farklı vasıtalarla karşı cephelere yerleşim merkezlerine ulaştırılmıştır. ${ }^{95}$ Nadiren bu şubeler dışında hazırlanan bildiriler ve mektuplar da olmuştur ki bunun örneğine Çanakkale'de daha sık rastlandığı söylenebilir. Bunlar daha çok ön hatta bulunan birlikler tarafından el yazısıyla yazılmaktaydı. Örneğin 42. Tümen'in 28 Eylül 1915 tarihli istihbarat bülteninde

\footnotetext{
91 TNA, W.O. 95/4304, 29 DIVISION, Headquarters Branches and Services: General Staff, 1915 Jan.-June, Intelligence Bulletin, Appendix-1.

92 TNA, W.O. 157/648, General Headquarters: Intelligence Summaries, General Staff 1915 Aug., Appendix 6.

93 Hamit Pehlivanlı, "Çanakkale Muharebeleri Sırasında Müttefiklerin Propagandası ve Karşı Propaganda", Atatürk Araştırma Merkezi Dergisi, Cilt: VII / Temmuz 1991 / Sayı: 21, s.537.

${ }^{94}$ Zekeriya Türkmen, "Psikolojik Harekât Açısından Çanakkale Muharebelerine Dair Bir Değerlendirme", 15.Askeri Tariz Sempozyumu, Ankara 2017, s.334.

95 Sadık Sarısaman, Birinci Dünya Savaşı'nda Türk Cephelerinde Beyannamelerle Psikolojik Harp, Ankara 1999, s.7.
}

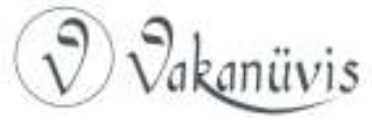


İngilizlere firar eden bir Türk askerinin, Zığındere bölgesindeki Türk siperlerine mektup atılmasına izin verildiği belirtilmekte ve bu hadise istihbarat bülteninde şu satırlarla anlatılmaktadır:

"Türk esirin mayın çukurundan arkadaşlarını çağırmasına ve tarafımızca iyi muamele edildiğine dair tanıklık eden bir mektubu atmasına izin verildi. Bundaki amaç başka Türklerin de bize firar etmesini tetiklemekti. Kısa bir süre sonra çukurun kuzey kenarında sürünen 2 Türk görüldü ancak içeri girmediler. Çukurdaki firari Türk ve 2 subayımıza ateş edilmedi."

Çanakkale Savaşının, başından sonuna kadar her iki ordu da karşı tarafın moralini bozmak için çok sayıda çeşitli beyanname hazırlamıştır. Ingilizler çoğunlukla Türk askerlerini ilticaya davet etmiş ve çeşitli ifadelerle savaşın anlamsızlığını empoze etmeye çalışmıştır. ${ }^{97}$ Örneğin bir bölümü Times gazetesi sayfalarından, bir bölümü de propaganda şubesi tarafından hazırlanan bir beyannamenin iç sayfalarında "Osmanlı Zabitanına açık mektup" başlıklı bir yazı kalem alınmıştır. ${ }^{98}$ Yine bir başka propaganda beyannamesinde de subayların onayından geçen çeşitli fotoğraflar kullanılmıştır. Türkçe ve Arapça alt yazıyla Türk siperlerine atılan bazı fotoğraflar şunlardır: "Büyük İngiliz topları, Bol Ingiliz cephanesi, Alman hava sahası üzerinde uçup bomba bırakan bir İngiliz tayyaresi, İngiliz askerleri İngiliz taraftarı Mısırlı mücahitlerle birlikte" ${ }^{\prime 99}$

Diğer yandan propaganda yapmak için sadece yazılı beyannameler kullanılmamış, siperlerin birbirine yakın olduğu yerlerde sözlü propaganda da yapılmıştır. Ingiliz birliklerinde iyi derecede Türkçe konuşabilen ve yazabilen istihbarat subayları vardı. Ağustos ayında Anafartalar'a (Suvla) çıkarma yapan 9. Kolorduya ait 11. Tümen'de Üsteğmen A. Lander, iyi derecede Türkçe konuşup okuyabiliyorken Rumca ve Almanca da biliyordu. 10. Tümen subaylarından Üsteğmen C.A. Hooper, Türkçe, Farsça, Arapça ve Almanca bilirken, 13. Tümen istihbarat subaylarından Üsteğmen G.D.V. Gout ise Türkçe, Rumca ve

\footnotetext{
96 TNA, W.O. 95/4313, 42 DIVISION, Headquarters Branches and Services: General Staff, 1915 May-Dec., 28 September 1915.

97 Sarısaman, a.g.e, s.80.

98 a.g.e, s.5.

99 a.g.e, s.14.
}

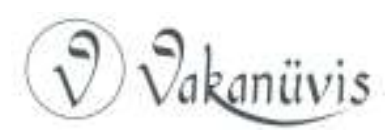


Arapça konuşabilmekteydi. ${ }^{100}$ Türkleri iyi tanıyan ve çok iyi seviyede Türkçe konuşan İngiliz istihbarat subayı Aubrey Herbert, anılarında Türklere yakın olan siperlere giderek propaganda konuşmaları yapması için emir aldığını açıkça belirtir. Kendi ifadesine göre, konuşmalarında öne çıkan iki önemli unsur vardır. 1- Türk esirlerin son derece iyi şartlar altında yaşadıkları. 2-Ingilizlerin Türklerle bir sorunu olmadığı, asıl düşmanlarının Almanlar olduğu. Aubrey Herbert, anılarında yaptığı konuşmaları şöyle anlatmaktadır:

"Siperlerde Türklerle karşı karşıya yaptığım konuşmalarda genelde hep aynı şeyi söyledim; biz esir alıyorduk ve onlara iyi davranıyorduk. Temel sorun bizimle Almanlar arasındaydı, ingilizler ile Türkler arasında değildi; Türkler, Kırım'da bizim dostumuz idiler. Bir Türk atasözünü alıntılayarak sözlerimi tamamlıyordum: "Eski dost düşman olmaz" Hatlarımız Türk hatlarına çok yakındı, megafonla veya onsuz anlaşılır biçimde konuşabiliyordum." ${ }^{101}$

Yine kendisinin aktardıklarına göre bu konuşmalar Türkler üzerinde çok fazla etkili olmamaktaydı ve her seferinde çok sert cevap veriyorlardı. Konuşmasının hemen ardından bulunduğu siper Türkler tarafından yoğun şekilde bombalanıyordu. Sadece Aubrey Herbert değil, diğer istihbarat subayları da savaş süresince pek çok kez ileri hatta giderek Türklere karşı propaganda konuşmaları yaptı. İstihbarat raporlarına giren konuşmalar arasında en çarpıcı olanlardan biri de 12 Ekim tarihinde Arıburnu'nda yaşanmıştır. Daha önce aynı bölgeden Ingilizlere firar eden Süleyman isimli bir Türk'ü de yanına alarak Yükseksırt'ta Türk siperlerine en yakın noktaya giden istihbarat subayı Üsteğmen Woods, burada Türk askerleriyle son derece enteresan diyaloglar içine girmiştir. Bu hadise bütün ayrıntılarıyla raporlanmıştır. Bu enteresan olayın önemli kısımları şöyle aktarılmaktadır:

"Dün elime megafon alarak Süleyman ve Addison ile Türk siperlerinden birkaç metre uzaktaki (bu noktanın Türklere en yakın yer olduğunu düşünüyorum) bomba çukurunun içine girdik. Süleyman, kendi aralarında konuşmalarını duyduğumuz Türklere bağırdı. Sadece "ai, ai" [belgenin orijinalinde böyle yazılmış] diye

\footnotetext{
100 TNA, W.O. 95/4276, 9 CORPS, Headquarters Branches and Services: General Staff, 1915 June-Sept., 20 July 1915.

${ }^{101}$ Aubrey Herbert Henry Morgenthau Çanakkale Devler Ülkesinde Devler Savaşı, , Çev: Seyfi Say, İstanbul 2007, s.53-54.
}

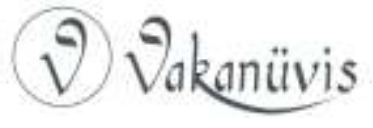


cevap verdiler. Türkler siperdeki diğer arkadaşlarına da haber verdiler. Söylediğimiz her bir kelimeyi rahatlıkla duyabiliyorlardı. Daha sonra sabah saat 07.00'de bir grup Türk, elleri başları üzerinde (bizim tarafa gelmek isterlerse böyle yapmalarını söylemiştik) siper duvarında gözüktü. Bizimkiler onlarla konuşmadı fakat sigara ile sığır eti konservesi attılar. Konserveyi alabilmek için Türkler arasında müthiş bir karışıklık çıktı. Bir konserve Türk siperlerinin içine değil önüne düştü ve bir Türk siperinden çıkarak bu konserveyi aldı. Bunun üzerine Addison ve Calaughan bomba çukuruna giderek Türklere bağırdılar: "Eğer siperlerinize gelirsem sonra geriye dönmeme izin verir misiniz?" Türkler şöyle karşılık verdi: "Biz erkeğiz ve sana söz veriyoruz" Daha sonra başlarını bomba çukurundan kaldırdılar ve Türk siperlerinden başı ve omzu gözüken bir Türk gördüler. Addison kendisini gelmesi için davet ederek; "eğer gelirsen sana iyi bakılacak ve mutlu olacaksın. ingilizler ve Türkler her zaman arkadaştır" dedi. Türk: "Biz burada mutluyuz" diye cevap verdi. Addison, Türk askerine ne demesi gerektiğini söyleyen bir Türk subayını fark edince bu işe bir son verdi."102

Üsteğmen Woods, 20 Ekim'de Kurmay Yüzbaşı Deedes'e ${ }^{103}$ verdiği raporda Anzak siperlerinden Türklerle propaganda amaçlı nasıl en sağlıklı şekilde iletişim kurulabileceği ve onları firar etmeye nasıl ikna edilebileceği konusunda çeşitli önerilerde bulunuyordu:

"Bombasırtı'ndaki Türkler iki günden beri omuzlarına kadar siper duvarından çıkarak bize dostluk emareleri gösteriyorlar ve bir Türk subayı siperden geçerken kafamızı eğmemiz gerektiğini işaret ediyorlar. Bunun muhtemel sebebi, daha önce sizin gönderdiğiniz

102 TNA, W.O. 95/4283, 1 ANZAC, Headquarters Branches and Services: General Staff, 1915 Oct.-Nov., 12 October 1915.

103 Sir Wyndham Deedes: Gelibolu'da İstihbarat subayı olarak Kurmay Yüzbaşı rütbesiyle görev yapan Deedes, 1910-1911'de Libya'da Türk Jandarmasında görev yapan İngiliz subaylarındandı ve daha sonra Türk Dahiliye Nezaretinin bir parçası olarak Anadolu'da görev yaptı. Gelibolu'dan sonra Arap İsyanı başlarken Kahire'de danışman subay olarak bulunuyordu. Tarihi bir gün olan 11 Aralık 1917'de General Allenby ile Kudüs'e girdi. I. Dünya Savaşı'ndan sonra İstanbul'daki İngiliz Yüksek Komiserliği bünyesinde çalıştı ve 1919 'da Filistin'de Herbert Samuel'in atında Genel Sekreter olarak görev yaptı. 1910 yılından itibaren Türklerle birlikte, 1915'ten sonra ise Türklere karşı görev yapan Deedes, Türkleri, Anadolu ve Orta Doğu'yu iyi tanıyordu ve çok iyi derecede Türkçe biliyordu.. Ayrıntılı bilgi için bknz: John Presland, Deedes Bey-A Study of Sir Wyndham Deedes 1883-1923, London 1942.

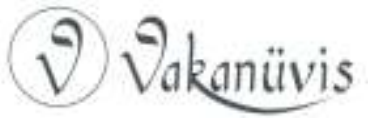


mektupları Yükseksırt ve sonra Bombasırtı'ndaki Türk siperlerine atmamız olabilir. Aslında bize firar eden Süleyman'ı buraya getirip siper duvarından Türklere göstererek onu konuşturmayı düşündüm ama bu kendisi için çok riskliydi. Türklerin arasından bir fanatik, bize firar etmiş ve diğerlerinin de firar etmesini öğütleyen birini görünce onu vurmak isteyebilirdi. Diğer alternatif ise siper duvarından bağırarak Türkleri davet etmekti ama kişisel olarak bunun da doğru olmadığını düşünüyorum. Karşımızdaki Türklerle arkadaşça ilişki kurduk ve bağırarak Türk subaylarının dikkatini çekip şüphelenmelerini istemiyorum. Bence yapılacak en iyi şey mektubu bir konserve kutusuyla Türk siperlerine atmaktır. Böylece onlara direk ulaşabiliriz. Mektupta bize nasıl gelmeleri gerektiğini, (silahsız ve elleri yukarda olacak şekilde) onlara göz kulak olarak yardım edebileceğimizi ve istedikleri zaman gelebileceklerini söyleyebiliriz. Bize firar etmelerini daha cazip hale getirmeliyiz. Alman askerlerinin Türkiye'ye gelecekleri ve bir daha geri dönmeyecekleri, bunun Türkiye’nin sonu olduğu argümanı fayda sağlayabilir. Bu konularda bana katılıyorsanız etki yaratabilecek 1 veya 2 mektubu Türkçe olarak bana gönderebilir misiniz?"104

Türkler de İngilizler gibi karşı tarafın askerlerini etkilemek için aynı propaganda silahını sıklıkla kullanmıştır. Yükseksırt ve Bombatepe bölgelerinde Anzak siperlerine atılan Türk propaganda notları, 17 Ekim tarihli istihbarat bülteninde yer almaktadır. Bu notlar son derece çarpıcı ifadeler barındırırken, bazı kısımları ise sert söylemlerden oluşmaktadır:

"Uygarlık maskesi altında yaşayan domuz ingilizlere: Türkler aç veya çıplak değil. Midelerimiz her zaman dolu ve halimizden memnunuz. Aç bile olsak onurumuz tüfeğimizin ucundaki süngüye bağlı durumdadır. Sizin toplarınız ve silahlarınız, Türklerin cesareti ve süngüsü var. Eğer yemek veya sigara sıkıntınız varsa bize haber verin. Biz size bunları veririz. Ellerinizdeki bütün mühimmatla neyi başarmaya çalıştığınız mühim değil. Bizim süngülerimizi ve düşüncelerimizi yenemezsiniz. Evet, burada ingilizlerin onur ve medeniyetten ne kadar uzak olduklarını bilmeyen tek bir Türk askeri yok. Eğer gerçekten onurlu bir ulus olduğunuzu söylüyorsanız, askeri görevinizi yerine getirmeye çalışın ve yaptığınız şeyi yapmayın"

104 TNA, W.O. 95/4283, 1 ANZAC, Headquarters Branches and Services: General Staff, 1915 Oct.-Nov., 20 October 1915.

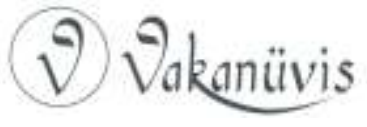


Bu nottaki sert ifadelere bakılırsa, Anzakların savaş kurallarına aykırı bir davranış içine girdikleri ve bir hadise yaşandığı özellikle son cümlelerden anlaşlıyor. Bombatepe'ye atılan ikinci not ise daha uzun yazılmış. İçinde yer alan önemli kısımlarda şu cümleler yer almakta:

"Bize asilce yazdığınız ilanı gerektiği gibi aldık. Yazdıklarınıza bakılırsa tamamen aptal olmalısınız. Şuna emin olabilirsiniz ki böyle aşağılık ve aptalca teklifler yaparak sadece kendinizi kandırabilirsiniz. Emin olun bugüne kadar avantajlı olan taraf hep bizdik. Boğaz'ı ele geçirmek için karaya çıkardığınız bütün kuvvetler bizim taarruzlarımız sayesinde geriye atıldı. Ama siz zavalılar, ölen arkadaşlarınız gibi aynı ölümcül sona katlanmak zorunda kalacaksınız. Eğer hayatınızı kurtarmak isterseniz, bize katılın."105

Türklerin Seddülbahir'de İngiliz siperlerine attığı bir başka notta ise;

"Biz ülkemizi ve dinimizi korumak için savaşıyoruz. Biz Türkler adam öldürmeyi sevmeyiz, ama ülkemizi işgale gelenlerin kanını içeriz. Boş yere kanınızı dökmeyin ve gelin teslim olun. Elimizdeki esirler iyi durumda ve bize teşekkür ediyorlar. Sizi yarımadadan göndermeye kararlıyı. Zaman bunu gösterecek. Bir Türk asla dinlenmez, elinde tüfeği vardır ve elleri asla kırılmaz"106

Ifadeleri yer almaktadır. Şüphesiz bu mektuplar, Türk subayları tarafından kaleme alınmıştır. Diğer yandan İngilizlerin "Türkler aldıkları esirleri öldürüyor" propagandasına karşı hem bunun yalan olduğunu bildirmek hem de İngiliz askerlerin savaşma azmini kırmak için 100 nüshadan oluşan bildiri, 12 Mayıs 1915'te uçaklarla İngiliz siperlerine atımıştır. "Ey İngiliz, Avustralyalı, Yeni Zelandalı, Fransız ve Hintliler" diye başlayan bu beyannamede Türklerin esirlere yaptığı iddia edilen kötü muamele yalanlanmakta "bizdeki esirlerin rahat ve huzuru pek mükemmeldir" denilmektedir. ${ }^{107}$

Aslında her iki tarafta çarpışan askerler de hem kendi orduları hem de düşman ordu tarafından yapılan propagandaya maruz kalmaktaydılar. Kendi ordusundaki subaylar, askerlerin savaşma azmini

105 TNA, W.O. 95/4305, 29 DIVISION, Headquarters Branches and Services: General Staff, 1915 July-1916 Feb., October 1915, Appendix-14.

106 TNA, W.O. 95/4313, 42 DIVISION, Headquarters Branches and Services: General Staff, 1915 May-Dec., September 1915, Appendix-3.

107 Pehlivanlı, a.g.m, s.548.

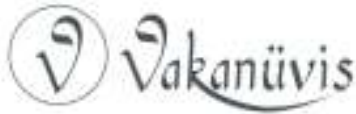


arttırmak, uzayan savaşın yarattığı kötü siper hayatı şartlarından bıkan askerlerin karşı tarafa kaçmaması ve asla teslim olmamasını sağlamak için, esirlere ve firarilere son derece kötü davranıldığını, hatta öldürdüklerini empoze etmeye çalışıyordu. Karşı ordu ise bu propagandaya karşı propaganda ile cevap vererek, esirlerin çok iyi şartlarda yaşadıklarını, yaralarının tedavi edildiğini ve mutlu olduklarını oldukça abartılı ifadelerle, sanki savaşın o kötü şartları hiç yokmuşçasına anlatıyordu. Şüphesiz bütün bu ifadeler oldukça abartılıydı ve hiçbir şekilde gerçekleri yansıtmıyordu. Bu propagandaya verilebilecek en güzel örneklerden biri İngiliz 9. Kolordusunun harp günlüklerinde görülmektedir. 29 Eylül tarihinde, Genel Karargâh istihbarat biriminden 9.Kolordu Komutanlığına gönderilen emirde, ele geçirilen bir Türk esirin yazdığı iddia edilen mektubun 100 kopyasının gönderileceği ve bunların bir fırsatının bulunarak Türk siperlerine atılması istenmiştir. Mektupta esir düşen Türklerin durumunun iyi ve mutlu oldukları yazılıdır. Emrin devamında, amacın Alman ve Türk subayların İngilizlerin aleyhine yaptıkları; "Ingilizler esir aldıkları askerlere kötü davranıyor" algısının yıkılmak istendiği belirtilmiştir. ${ }^{108}$

Bugün bu mektubun Türk siperlerine atılan eski Türkçe hali (metnin sonunda ekler kısmında görülebilir) ve İngilizce tercümesi 9. Kolordunun harp günlüklerinde bulunmaktadır. "Silah arkadaşlarıma" hitabıyla başlayan "Bir Osmanlı esiri" imzasıyla sona eren mektubun dikkat çeken kısımları ise şöyledir:

"Esir düştükten sonra tedavi sürecim bize anlatılanları tam tersi olduğu için size şu cümleleri kurmayı kendime görev biliyorum. Yakalandıktan sonra beni alan subaylar bana iyi davrandılar ve herkes bana hediyeler verdi, sigara ikram ettiler. Yolda subaylar ve askerler bana silah arkadaşları gibi davrandılar ve beni mutlu etmek için her şeyi yaptılar. Daha sonra Gökçeada'ya getirildim ve diğer esir düşen arkadaşların arasına katıldım. Hepsine yeni iç çamaşırları ve üniformalar vermişlerdi. Her çadırda yalnızca 5 adamımız kalıyor ve adam başı 3 battaniyemiz var. Büyük miktarda savaş malzemesi depoları var. Her bir esire günde 50 dirhem şeker, 20 dirhem çay, 75 dirhem pirinç, 60 dirhem patates, 75 dirhem sebze ve 150 dirhem yemek düşüyor. Ayrıca ekmek, bisküvi ve her iki günde bir paket sigara

108 TNA, W.O. 95/4276, 9 CORPS, Headquarters Branches and Services: General Staff, 1915 June - Sept., 29 September 1915, no: 34.

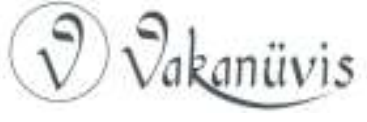


veriliyor. Buradaki arkadaşların hepsi tek kelimeyle çok mutlu. Hepimiz sizin seri şekilde firar etmeniz için dua ediyoruz."

İngilizler savaş boyunca Türk siperlerine teslim olmalarına dair pek çok beyanname atmışlardır. 28 Temmuz 1915'te Kumkale bölgesine havadan attıkları notlarda, Türk esirlerinin Nil nehri kenarında gayet muntazam bir bahçede ikamet ettikleri ve her birinin ayrı yatağı olduğu, çeşit çeşit yemekler yedikleri yazmaktadır. Hiç şüphesiz gerçekler böyle değildir. İngilizler, esirlere iyi muamele ettiklerini ve bunların kıymet itibariyle İngiliz askerlerinden aşağı olmadığını göstermeye çalışmışlardır. Ingilizlere sığınanların bolca yeme içme imkânına sahip olacaklarını, hatta esirlere maaş ödendiğini kaydetmektedirler. Zorluklar içinde her türlü imkândan yoksun savaştı̆̆ına inandıkları Türk askerlerini bu şekilde ikna etmeye veya kandırmaya çalışmışlardır. Bir Türk esirin ilk yakalandığı andan itibaren kampa getirilmesine kadar olan süreçte başından geçenler ve kamp yaşantısını resmeden fotoğraflar da propaganda malzemesi olarak kullanılmıştır. ${ }^{110}$ Fotoğraflarda rahat ve huzur içinde sigara ve nargile içen, saz ve tef çalan, tespih çeken Türk askerleri, adeta her türlü denetimden yoksun ve serbestçe yaşadığı izlenimi verilmeye çalışılmıştır. ${ }^{111}$ Arıburnu'nda 57. Alay siperlerine atılan bir notta ise şöyle yazılmıştır:

"Ey Türk kardeşlerimiz! Ingilizlerin aldıkları esirlere kötü muamele ettikleri ve hatta kestikleri hakkında çıkarılan rivayetler Almanların yalanlarıdır. Esir düştükleri zamanda aç, çıplak, perişan olan Osmanlı askerlerine ingiliz Hükümeti tarafından fevkalade iyi bakılmıştır. Mezkûr yalanlara kulak vermeyip esir düşmüş arkadaşlarınızın refahına siz de iştirak ediniz"112

23 Aralık 1915 tarihinde Seddülbahir'e atılan bir beyannamede de isimleri ve alayları belirtilen 18 esir Türk askerinin imza, mühür ve parmak izinin altında İngiliz ve Fransızların ellerindeki esirleri mükemmel şekilde yedirip içirdikleri, hasta ve yaralıların ise özenle

\footnotetext{
109 TNA, W.O. 95/4276, 9 CORPS, Headquarters Branches and Services: General Staff, 1915 June - Sept., September 1915.

${ }^{110}$ Sarısaman, a.g.e, s.14.

111 a.g.e, s.15.

112 Pehlivanlı, a.g.m, s.538.
}

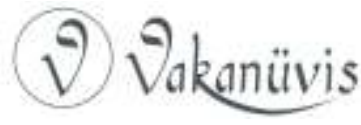


tedavi edildiği kaydedilmektedir. ${ }^{113} 27$ Mayıs 1915 'te Arıburnu'ndaki siperlere atılan ve esir Türk askerlerinin ağzından yazılan bir başka notta ise şu ifadeler yer almaktadır: "Ingilizler bizi iyice yedirip temiz su verdikten başka tütün ve diğer isteklerimizi karşıladılar. Yaralı olanlarımız hekimler tarafından tedavi edildi. Hatta çalıştırdıkları neferlere dahi emeklerine mukabil ücret veriliyor."114

Bu bildirilerin ve mektupların diğer tarafı ne kadar etkilediği veya ne derece başarı sağlandığını tespit etmek kolay değil. Fakat attıkları mektup ve bildirilerin Türkler üzerinde etkili olup olmadığı İngilizler tarafından sorgulanmıştır. Türk esirlerin ifadelerinden öğrendiğimize göre, İngilizler uçaktan atılan bildirileri ve kaçak mektuplarını (Daha önce belirtildiği gibi İngilizlere firar eden Türk askerlerinin ağzından yazılan propaganda mektupları uçakla, veya yakın olan Türk siperlerine elle atılıyordu. Bazen de İngiliz devriyeleri geceleri Türk siperlerinin kenarlarına bu mektupları gizlice bırakıyorlardı) ${ }^{115}$ görüp görmediklerini esirlere sormuşlardır.

9. İngiliz Kolordusunun 15 Ekim 1915 tarihli bir emrinde esir ve kaçaklara sorulması gereken önemli sorular 34 madde halinde sıralanırken bu soruların ilk maddesi Türk firari veya esirlerin ağzından yazılan ve Türk siperlerine atılan mektupları görüp görmedikleriyle alakalıdır. ${ }^{116}$ Örneğin 33. Alay'dan İsmail oğlu Sadık ifadesinde sorulan soru üzerine, uçaktan bazı kâğıtların atıldığını fakat kendisinin bunları görmediğini, kaçak mektuplarından haberi olmadığını ve birliğinde düşmana teslim olmak isteyen herhangi bir askerin bulunmadığını belirtmiştir. ${ }^{117}$ Bir başka esir ifadesinde ise daha enteresan bilgiler mevcut. 127. Alay'dan Kalfas isminde bir Rum askeri, kaçak mektuplarını görmediğini ama subayların siperlere gelerek İngilizlerin uçaklardan mektuplar attıklarını ve bu mektuplarda Türklere savaş

\footnotetext{
113 Sarisaman, a.g.e, s.84.

114 Pehlivanlı, a.g.m, s.539.

115 TNA, W.O. 95/4277, 9 CORPS, Headquarters Branches and Services: General Staff, 1915 Oct.-Nov., 8 October 1915.

116 TNA, W.O. 95/4277, 9 CORPS, Headquarters Branches and Services: General Staff, 1915 Oct.-Nov., 15 October 1915.

117 TNA, W.O. 95/4305, 29 DIVISION, Headquarters Branches and Services: General Staff, 1915 July-1916 Feb., 12 October 1915.
}

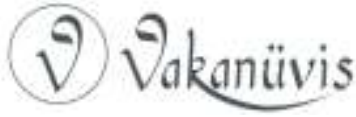


açtıkları için özür dilediklerini ve hastane gemilerine ateş açılmaması için yalvardıklarını söylediğini belirtmiştir. ${ }^{118}$

Türk askerlerinin büyük çoğunluğu okuma yazma bilmediği için bu mektupların askerler üzerindeki etkisi tartışmalıdır. Son örnekte görüldüğü gibi, askerler İngiliz uçaklarından atılan bu metinleri okuyamadıklarından, Türk subayları İngilizlerin kendi metinlerini karşı propaganda aracı olarak kullanmışlardır. Diğer yandan, bazı esir-kaçak ifadelerinden öğrendiğimiz kadarıyla (subayların bütün çabalarına rağmen) Türk askerlerinin bahsedilen kaçak mektuplarından haberdar oldukları ve etkilendikleri görülmektedir. Örneğin 5 Aralık 1915 te Anafartalar'da İngilizlere firar eden 34. Alaydan Er İbrahim oğlu Osman, neden İngilizlere sığındığı ile ilgili soruya, arkadaşlarından Ingilizlerin esirlere iyi davrandıklarını duyduğunu ve Türk-Alman subaylarının zorbalıklarından bıktığını ifade etmiştir. ${ }^{119}$ Yine 8 Aralık'ta Ingilizlere firar eden 34. Alaydan Muhammed oğlu Abdullah da ifadesinde, askerlerin kendi aralarında İngilizlerin esirlere iyi davrandığı ve savaşmaktan yoruldukları için teslim olmak istediklerini konuştuklarını belirtmiştir. ${ }^{120}$ Anzak Kolordusu günlüğünde de 1. Avustralya tümeni bölgesinden Türk siperlerine kaçak mektubunun kopyalarının atılığı ve bir müddet sonra Türk siperlerinden teslim olma belirtileri gözüktüğü not edilmiş fakat teslim olup olunmadığına dair bir bilgi verilmemiştir. ${ }^{121} 17$ Ekim tarihinde buna benzer bir başka hadise Kanlısırt'ta yaşanmış ve kaçak mektuplarının atılmasından sonra bir Türk'ün siperlere yakın bir noktada konuştuğu tespit edilerek bölgeye tercüman gönderilmiş fakat ne dediği bir türlü anlaşılamamıştır. 6 Ekim'de Bombatepe'de siperlerine atılan kaçak mektuplarını alan Türkler, kaçak mektubuyla birlikte yazdıkları cevap

\footnotetext{
118 TNA, W.O. 95/4305, 29 DIVISION, Headquarters Branches and Services: General Staff, 1915 July-1916 Feb., 23 October 1915.

119 TNA, W.O. 95/4278, 9 CORPS, Headquarters Branches and Services: General Staff, 1915 Dec., 5 December 1915. Esir ifadelerine bakıldığında (bu örnekte olduğu gibi) erlerin çoğunun subayların kendilerine kötü davrandıklarını belirtmeleri de dikkat çeken bir diğer önemli husustur.

120 TNA, W.O. 95/4278, 9 CORPS, Headquarters Branches and Services: General Staff, 1915 Dec., 8 December 1915.

121 TNA, W.O. 95/4283, 1 ANZAC, Headquarters Branches and Services: General Staff, 1915 Oct.-Nov., 1 October 1915.
}

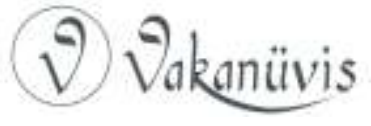


kâğıdını Avustralyalıların siperlerine geriye atmıştır. ${ }^{122}$ Sonuç olarak, bu eylemler karşılıklı olarak neredeyse her gün yaşanmaya devam etmiştir.

İngiliz birliklerinin istihbarat raporlarına giren bir başka propaganda unsuru ise, Akdeniz Seferi Kuvvetleri baskı biriminin kendi askerleri için günlük olarak çıkarttı̆̆ı "Yarımada Gazetesi"dir. Kendi askerlerinin morallerini yükseltmek ve savaşma azimlerini arttırmak için çıkarılan bu gazete ile haberler Arıburnu ve Seddülbahir'deki askerlere ulaştırılmıştır. Gazetenin sayfalarına bakıldığında sadece Gelibolu'daki muharebeler ile ilgili değil, savaşın genel gidişatı ile ilgili dünyanın her yerinden çeşitli haberler verildiği görülmektedir. 16 Mayıs 1915 tarihli baskının ilk sayfasında, "italya ve Savaş, Fransa'daki Operasyonlar, Rusların Denizlerde Aktiviteleri, Yunanistan'ın Tavrı" gibi çeşitli başlıklar yer almaktadır. ${ }^{123}$ Günlük olarak çıkan bu gazetede Gelibolu'da yaşanan enteresan olaylara da yer verilmiş ve Türklerle ilgili çarpıcı saptamalar yapılmıştır. 17 Mayıs 1915 tarihli baskıda "Ağaç gibi yürüyen Türkler" başlığının altında şunlar yazmaktadır:

"Üstündeki ekipmanları kendisini noel ağaçları gibi gösteren askerleri duymuştuk ama Türkler bunun daha iyisini yapmış. Avustralyalıların raporlarına göre tam olarak bir ağaca benzeyen bir Türk keskin nişancısı ele geçirilmiş. Bütün vücuduna fundalıklardan öbek öbek çalı çırpı sıkıştırmış. Hatta söylenene göre tüfeğini ve yüzünü bile yeşile boyamış. Onu yakalayan askerlerin belirttiğine göre, vadiden aşağı yürürken iki üç el kurşun vızıltısı duymuşlar ve dönüp baktıklarında küçük bir çalının hareket ettiğini görmüşler. Ağaç adam yakalandığında üstünde biraz Avustralya parası ve künyeler çıkmış. Üstünden çıkanlar ile alakalı genel fikir, öldürdüğg̈ adam başına ödüllendirildiği ve ödülünü almadan önce bu künyeleri vermek zorunda olduğuydu"

Aynı sayfanın sonunda ise "Müttefiklere Müslüman Desteği" başlığında İngilizler ile iş birliği yapan Araplar övülmüştür. Arapların

\footnotetext{
122 TNA, W.O. 95/4283, 1 ANZAC, Headquarters Branches and Services: General Staff, 1915 Oct.-Nov., 6 October 1915.

123 TNA, W.O. 95/4304, 29 DIVISION, Headquarters Branches and Services: General Staff, 1915 Jan.-June, 16 May 1915, No:4.
}

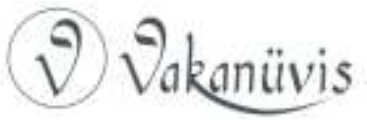


Türkler kadar saf olmadıkları, Almanların anlattığı İslam'ı koruma ve yüceltme masallarını yemedikleri ve Almanların Müslümanları müttefiklere karşı kutsal savaşa çağırma çabasının yüz kızartıcı şekilde başarısız olduğundan bahsedilmektedir. ${ }^{124} 19$ Mayıs tarihli bültende ise Arıburnu'nda gerçekleştirilen büyük Türk taarruzundan ayrıntılarıyla bahsedilirken, "Türkler ilerlemek için büyük cesaret ve kararlılık gösterseler de kitleler halinde tüfeklerimiz tarafından biçildiler" denmektedir. ${ }^{125}$ Bültenler içinde çok çeşitli bilgiler yer alırken, Ingiltere'den Fransa'ya her gün 400.000 mektup ve 50.000 paket yollandığı, Çanakkale ve Mısır'a ise her hafta 250.000 mektup ve 5.000 koli geldiği gibi enteresan bilgiler de verilmiştir. ${ }^{126}$ Kendi askerlerinin moral motivasyonunu arttırmak için propaganda amaçlı sürekli iyi haberlerin verildiği bu gazete, askerlerin dış dünyadan haber alabildikleri yegâne unsurdu. 22 Mayıs tarihli Yarımada Gazetesinin arkasına ufak bir not yazarak ailesine yollayan Avustralyalı bir asker, biraz da şaşkınlıkla "Kötü haberleri almıyoruz. Bilgi alabildiğimiz tek kaynak bu gazete" diye yazacaktı. ${ }^{127}$

Askerler arasında bu propaganda gazeteleri ve sayfalarının ne derece etki yaptığı tartışmalıdır. Zira istihbarat subaylarından Compton Mackenzie kendisinden ertesi gün taarruza kalkacak askerler için bir propaganda sayfası yazması istendiğinde, "Türklerde durumlar nasıl?" başlığını attıktan sonra içini farklı hikâyelerle süslemiştir. Propaganda amaçlı hikâyelerden en enteresanı ise şöyledir: "Gelibolu'da 20 Türk subayı ileri hatta gitmeyi reddetmiş ve bunlar tutuklanarak İstanbul'a gönderilmişlerdir. Sokaklarda elleri kelepçeli olarak yürütülürken içlerinden biri geçmekte olan askerlere: "gitmeyin, orası cehennem" diye bağırmış, derhal susturulduktan sonra vurulmuştur" Bunun gibi gerçek olmayan hikâyeler sıralandıktan sonra bu sayfalar çoğaltılarak askerlere dağıtılmıştır. Mackenzie günlüğünde bu yazıyı nasıl yazdığını

124 TNA, W.O. 95/4304, 29 DIVISION, Headquarters Branches and Services: General Staff, 1915 Jan.-June, 17 May 1915, No:5.

125 TNA, W.O. 95/4304, 29 DIVISION, Headquarters Branches and Services: General Staff, 1915 Jan.-June, 19 May 1915, No:7.

126 TNA, W.O. 95/4304, 29 DIVISION, Headquarters Branches and Services: General Staff, 1915 Jan.-June, 22 May 1915, No:10.

127 Peter Little, Men of Gallipoli, England 1988, s.157.

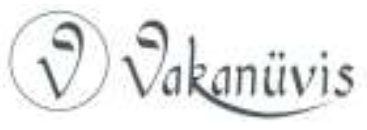


aktarırken en sonda şöyle demektedir: "herhangi bir askerimizin bu saçmalıkları okuyarak taarruz için cesaretlendiğine inanmak çok zor" ${ }^{128}$

\section{Esir İfadeleri}

İngilizlerin cephe ile ilgili en önemli istihbarat kaynaklarından biri de hiç şüphesiz ele geçirilen esirlerin ifadeleridir. Türklerin karşısında savaşan her birliğin istihbarat günlüklerinde onlarca hatta yüzlerce esir ifadesi mevcuttur. Esir düşenlerin yanında, bilerek ve isteyerek Ingilizlere teslim olan kaçakların ifadelerini de raporlarda görmekteyiz. İngilizler ele geçirdikleri Türk askerlerinin ifadelerinin başına "Esir ifadesi" diye başlık atarken, kendilerine sığınan askerlere "Kaçak ifadesi" diye başlık atmışlar ve bu iki grubu birbirinden ayırmışlardır.

Bilindiği gibi Türk ordusunda I. Dünya Savaşı'nın sonuna doğru, arka arkaya gelen felaketler ve merkeze uzak cephelerde yaşanan iaşe sıkıntısı dolayısıyla esir ve kaçak sayısı çok ciddi oranlarda artmıştır. Çanakkale Muharebeleri'nde ise durum daha farklıdır. Gerek bölgenin merkeze yakın olması, gerek muharebelerin henüz savaşın ilk döneminde cereyan etmesi, gerekse muharebelerin hareketli değil de siper savaşı karakteristiğinde olması sebebiyle özellikle firar konusunda (25 Nisan ve sonraki birkaç günde Arıburnu'nda yaşanan bazı toplu firar hadiseleri haricinde) diğer cephelerin aksine önemli bir sıkıntı yaşanmadığını görmekteyiz. Esir ve kaçak askerler konusu başlı başına ayrı bir çalışma konusu olmakla birlikte, esir düşen veya İngilizlere firar eden askerlerin istihbarat raporlarına giren ifadeleri ve verdikleri bilgileri kısaca inceleyeceğiz.

İngilizler esir ifadelerini özenle ve belli bir sistematiğe göre almışlardır. Birlik komutanı esir aldığı askeri nerede, ne zaman ve nasıl teslim aldığı ile ilgili kısa bir not tutarak bunları daha geriye göndermekle yükümlüdür. Tümen karargâhında esirlere bir seri numarası ve rehber verildikten ve buradaki sorgudan sonra mümkün olan en kısa sürede yarımadadan alınarak Gökçeada'daki esir kampına götürülmekteydiler. Bu konuda 9. Kolordunun 2 Ağustos 1915 tarihli emrinde, esirlerin nasıl Gökçeada'ya götürüleceği ile ilgili ayrıntılı bilgiler verilmiştir. Yine bu emre göre her esirin ifadesi ayrı ayrı rapor edilecek ve daha sonra faydalı bilgilerden bir rapor hazırlanarak

128 Mackenzie, a.g.e, s.197.

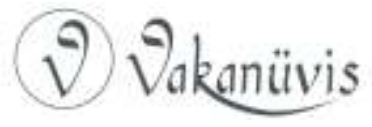


birliklere dağıtılacaktır. ${ }^{129}$ İyi derecede Türkçesiyle muharebeler boyunca pek çok Türk esirini sorgulayan Aubrey Herbet bu sistematiği anılarında şu ifadelerle anlatmaktadır:

"Türk kaçaklar ve esirler defalarca sorgudan geçiriliyordu. En önce Türk'ü ele geçiren bölge subayı faaliyete geçiyordu ve takdir görecek şekilde, istihbaratın yapacağı keşifleri erken davranıp önceden haber vermeye çok hevesli oluyorlardı. Sonra, bunun şerefi konusunda çok şiddetli kıskançık gösteren Başkumandanlık Karargâhı devreye giriyordu ve bunun ardından da bitkin durumdaki Türklerin son sorgulamasını yapmak için alabildiğine hırçın bir şekilde bekleyen Tümen Karargâhı işe başlıyordu. ${ }^{130}$

9. Kolordunun 30 Temmuz 1915 tarihli "Türk esirlerin ve evrakların incelenmesi ile ilgili notlar" başlıklı bildiride ise şimdiye kadar elde edilen tecrübelerden subay ve erlerin nasıl sorgulanması gerektiğine dair çeşitli tavsiyeler verilmiştir. Bu belgede subaylar hakkında "Bağlı oldukları alaylar haricinde bilgi vermeye gönüllü değiller" dendikten sonra, yine de subayların birkaç gün dinlendirildikten sonra konuşma konusundaki isteksizliklerinin geçebileceği vurgulanmıştır. ${ }^{131}$ Sıradan erlerin kendi çevrelerindeki birlikler hakkında makul denilebilecek bilgilere sahip olduğu ve rahatça konuştuğu gözlemlenmiştir. Astsubaylar hakkında yapılan değerlendirme ise son derece enteresandır: "Güvenilir bilgi vermesi en muhtemel olan grup astsubaylardır çünkü hem üstleri tarafından işe yarar derecede bilgilendirilmişlerdir, hem de subaylar kadar onurlu ve izzet-i nefis sahibi olmadıkları için sorulan sorulara karşı gelmemektedirler." Erlerin genellikle sıradan çiftçiler oldukları ve ele geçirildiklerinde muhtemelen kötü muamele görmelerinden dolayı korkarak belirsiz ve yanlış ifadeler verdikleri fakat belli bir müddet geçtikten, karınları doyurulup sigara ikram edildikten ve rahatladıktan sonra sorulan soruları cevaplamakta istekli olduklarına dair tespitler yapılmıştır. Türk

129 TNA, W.O. 95/4276, 9 CORPS, Headquarters Branches and Services: General Staff, 1915 June-Sept., 2 August 1915.

130 Herbert, a.g.e, s.138.

131 Yüzbaşı Deedes, Türk subaylarının savaştan bıkmaları, Almanların varlığından rahatsız olmaları ve Alman savaş taktiklerinin kendilerine ağır zayiata mal olması gibi sebeplerle sorgu esnasında işe yarar bilgi vermekten çekinmediklerini belirtmektedir. Deedes, a.g.e, s.181.

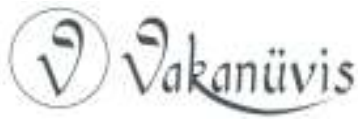


ordusundaki Hristiyan askerler için ise ordu hakkında en az bilgiye sahip olanlar bunlardır dendikten sonra, "çok az bilgiye vakıf olmalarına rağmen bilgi uydurma kapasiteleri bitip tükenmez" denmektedir. ${ }^{132}$

Esir ifadelerine baktığımızda çok çeşitli bilgiler verildiğini görmekteyiz. Sorulan sorular temelde aynı olmakla birlikte verilen cevaplar çok farklıydı. İngilizler hazırladıkları soru kitapçığında esirin memleketini, yaşını ve bağlı olduğu birlik numaralarını (bölükten orduya kadar) soruyordu. Esirlerin verdiği bilgiler ile birlik numaraları tespit ediliyor ve düzenli aralıklarla yarımadada hangi Türk birliğinin nerede olduğu, ne zaman bölgeye geldiği, yanındaki komşu alayların numaraları ve toplam Türk kuvveti ile ilgili toplanan bilgilerden çeşitli tablolar oluşturularak bunlar cephedeki İngiliz birliklerine istihbarat olarak dağıtılıyordu. Örneğin, 29. Tümen'in 28 Mayıs tarihli istihbarat günlüğünde esir ifadelerine göre; Türk alaylarının tam mevcutlu fakat eğitimlerinin yetersiz, toplarının az olduğu, ordunun büyük bölümünün Kafkasya'da Ruslarla savaşmak için gönderildiği ve yarımadada bulunan birliklerin yedek kuvvetler veya yeni oluşturulan birliklerden oluştuğu rapor edilmiştir. ${ }^{133}$

1 Haziran 1915 tarihli bir başka istihbarat raporunda ise, 30 Mayıs 1915'e kadar yarımadada olduğu belirlenen birlikler başlığı altında, hem Seddülbahir hem de Arıburnu bölgelerinde ön hatta veya yedekte bekleyen Türk alaylarının listesi tablo halinde hazırlanmıştır. ${ }^{134}$ Yarımadadaki Türk alaylarının listesi düzenli aralıklarla güncellenmiştir. $\mathrm{Bu}$ bilgiler esirlerden alındığı için Gelibolu'ya hangi Türk birliğinin geldiği ve bu birliklerin pozisyonları genelde doğru şekilde raporlanmıştır. Örneğin, 9. Kolordunun 9 Temmuz 1915 tarihli emrinde, ele geçirilen Türk esir ve kaçaklar sorgulanırken iki maddede şu bilgilerin temin edilmesi istenmektedir. Bu iki madde: 1-Triyandafil Çiftliğinin nerede olduğu, ne için kullanıldığı ve civarındaki irtibat

132 TNA, W.O. 95/4276, 9 CORPS, Headquarters Branches and Services: General Staff, 1915 June - Sept., 29 July 1915.

133 TNA, W.O. 95/4304, 29 DIVISION, Headquarters Branches and Services: General Staff, 1915 Jan.-June, 28 May 1915.

134 TNA, W.O. 95/4304, 29 DIVISION, Headquarters Branches and Services: General Staff, 1915 Jan.-June, 1 June 1915.

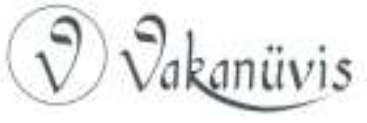


siperleri 2- Boyun noktasından Zığındere'ye inen yolun kesiştiği noktadaki kuyu civarında Türk pozisyonları ve bu kuyu etrafında olduğu söylenen mühimmat deposu hakkında bilgiler. Emrin sonunda ise esirler sorgulanırken mutlaka bağlı olduğu alayın pozisyonu ve komşu birlikler hakkında bilgi toplanması talep edilmiştir. ${ }^{135}$

Esirlerden öğrenilmeye çalışılan en önemli bilgilerden biri de Türk top mevzileri ve makineli tüfek yuvalarının yerlerinin tespiti ile alakalıdır. 11. Tümen 126. Alay’a ait bir Türk askerinin verdiği ayrıntılı bilgilere dayanarak Kirte gerisinde Sarıtepe'de bulunan dağ topları ve başka ağır toplardan oluşan Türk topçularının mevzileri, atış menzili ve hatta cephaneliğinin nerede olduğuna kadar ayrıntılı bir kroki çizilmiş ve rapor edilmiştir. Raporun altına ise, Ege denizine yakın olan bu top mevzileri için "denizden açılacak tarama ateşi bu mevziler üstünde güçlü etki edebilir" notu düşülmüştür. ${ }^{136}$ Bir başka raporda ise esirler ve diğer belgelerden elde edilen bilgilere göre Türk birliklerinin siperde nasıl konuşlandığı hakkında ayrıntılı bilgiler verilmiştir. Buna göre siperde bekleyen Türklerin dizilişi şu şekildedir: "Bir taburun iki bölüğü siperlerde 3 gün ve 3 gece bulunduktan sonra diğer iki bölükle yer değiştirmekte, yedekler 500 yard $^{137}$ geride beklemekte ve yer değiştirme işlemi karanlıkta yapılmaktadır. Gece vakti ise ön siperlere fazla asker getirilmemekte, adamlar 4 kişilik gruplara ayrılmakta ve gündüzleri bu dört kişiden ikisi hattı gözlerken ikisi dinlenmektedir. Gece karanlık çöktükten sonra dinlenmek ve uyumak yasaktır"138

9. Kolordunun 4 Eylül 1915 tarihli emrinde ise esirler içinde zeki olan Türklere "levazım ve ulaşım ile ilgili sorulması gereken sorular" başlığıyla 7 soru sorulması tavsiye edilmiştir. Bu sorular daha çok, tümenlerin ikmal depolarının yerleri ve hacmi, yarımadadaki büyük levazım depolarının (belgede bu maddenin yanına "büyük ağıllar" diye parantez içinde Türkçe olarak not düşülmüş) nerelerde olduğu, Bolayır'dan ön hatlara kadar malzemeler taşınırken hangi yolların

135 TNA, W.O. 95/4276, 9 CORPS, Headquarters Branches and Services: General Staff, 1915 June-Sept., 9 July 1915.

136 TNA, W.O. 95/4304, 29 DIVISION, Headquarters Branches and Services: General Staff, 1915 Jan.-June, 1 June 1915.

1371 yard $=0,9144$ metre

138 TNA, W.O. 95/4304, 29 DIVISION, Headquarters Branches and Services: General Staff, 1915 Jan.-June, 25 May 1915.

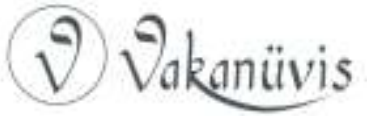


kullanıldığı ve bu malzemelerin hangi havyanlar vasıtasıyla getirilerek bölük ve taburlara kadar dağıtıldığı ile ilgili sorulardır. Bu belgenin sonuna düşülen notta ise şöyle yazmaktadır: "son zamanlarda genel karargâhta sorgulanan esirlerin bazılarından ilgili konular hakkında oldukça doğru bilgiler edinilmiştir." ${ }^{139}$

Esir veya kaçak askerin rütbesine ve verdiği bilgilere göre başka sorular da sorulduğu görülmektedir. Sorulan sorularda bir başka dikkat çeken ayrıntı ise İngilizlerin Türk ordusunda görevli Alman subayların varlığı ve hangi mevkilerde bulundukları ile ilgili bilgi toplamaya çalıştığıdır.

Ele geçirilen esir ve kaçakların çok çeşitli bilgiler verdiği belirtilmişti. Raporlarda esir düşen her Türk askerinin yaşadığı farklı tecrübelere binaen yemek, cephane, donanım, eğitim, ast-üst ilişkisi, moralmotivasyon ve savaşma azmi konusunda birbirine zıt ifadeler göze çarpmaktadır. Bazı esirler açlıktan şikâyet ederken, çoğunluk yemek konusunda bir sıkıntı yaşanmadığını belirtmektedir.

Bu noktada, günümüzde de sıklıkla tartışılan Çanakkale'de Türk ordusunun aç savaştığı iddiasının gerçeği yansıtmadığını belirtmek gerekmektedir. Esir ifadelerine bakıldığında da bu kanının doğru olmadığı net olarak görülmektedir. Örneğin, Anafartalar'da İngilizlere firar eden 23. Alay'dan Zileli iki Ermeni kardeş, Türk ordusunda yemek sıkıntısı olmadı̆̆ını belirtmişlerdir. Bu iki kardeşin ifadelerinde şu cümleler yer almaktadır: "yeterli derecede yemek var. Yiyecekler ekmek veya bisküvi, zeytin, peynir ve yağdan oluşmaktadır. Siperlerdeki askerlere düzenli olarak her 24 saatte bir saat 01.30 ' da çorba verilmektedir." ${ }^{140}$ Yine 126. Alay'dan bir onbaşı, yemek sorunu olmadığını her gece sıcak yemek yediklerini, bazen de sıcak kahvaltı yaptıklarını belirtmiştir. ${ }^{141} 29$ Ağustos'ta İngilizlere firar eden 1. Tümen 70. Alay'dan Mustafa oğlu Hasan ise ifadesinde bol yemek olduğunu ve

\footnotetext{
139 TNA, W.O. 95/4276, 9 CORPS, Headquarters Branches and Services: General Staff, 1915 June-Sept., 4 September 1915.

140 TNA, W.O 95/4305, 29 DIVISION, Headquarters Branches and Services: General Staff, 1915 July-1916 Feb., 6 October 1915.

141 TNA, W.O. 95/4305, 29 DIVISION, Headquarters Branches and Services: General Staff, 1915 July-1916 Feb., 15 October 1915.
}

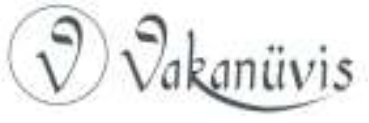


genellikle fasulye ile ekmek çıktığını belirtmiştir. ${ }^{142}$ 17. Alay 2. Taburun yedek subaylarından Burhaneddin Efendi de günlüğüne her sabah çay içildiğini, yemeklerin düzenli olarak verildiğini ve zeytin ile kuru üzümün bol olduğunu yazmaktadır. ${ }^{143} 72$. Alay'dan Er Hasan Sadullah ise daha ayrıntılı bilgiler vermektedir. Ifadesinde, sabah erken saatlerde çorba, öğlen peynir, zeytin ve kuru üzüm, akşamları ise bulgur ile birlikte fasulye veya bezelye, bazen de bu sebzelerin haşlamalarını yediklerini belirtmiştir. ${ }^{144}$ Bunun gibi onlarca ifadeden örnekleri çoğaltmak mümkün. Tekrar belirtmek gerekirse, karşılıklı büyük taarruzların yaşandığı günlerde en ön siperlere yemek ulaştırma sıkıntısı haricinde, Çanakkale'de iaşe bakımından büyük sorunlar yaşanmamıştır. Ambarlarda askere birkaç hafta yetecek kadar gıda maddesi depolanmıştır. ${ }^{145}$ Ingiliz istihbarat raporlarında da Türk ordusunun yemek konusunda sıkıntı yaşadığı veya aç halde savaştığına dair herhangi bir tespit görülmemektedir.

İngilizlerin esirlere ısrarla sorduğu bir başka soru da, Türklerin cephede zehirli gaz kullanma hazırlığı içinde olup olmadıkları ile ilgilidir. İncelenen esir ifadelerin tamamında askerler gaz kullanımı ile ilgili bilgilerinin olmadığını ve bu konu hakkında hiçbir şey duymadıklarını, Türk tarafında böyle bir hazırlığın olmadığını belirtmişlerdir.

İstihbarat raporlarının esir ve kaçaklar ile ilgili kısımlarına bakıldığında, en çok göze çarpan unsurlardan biri kaçak askerlerin sayısının fazlalığıdır. Örneğin bir Rum askerin verdiği bilgiye dayandırılan istihbarat raporunda, 24 Türk subay ve askerin firar nedeniyle Uzunköprü'de 4 Alman subay tarafından vurularak öldürüldüğü, daha sonra başka bir Türk komutanının bu 4 Alman'ı öldürdüğü gibi bilgiler de yer almaktadır. ${ }^{146}$ Ancak şu ana kadar ortaya

\footnotetext{
142 TNA, W.O. 95/4313, 42 DIVISION, Headquarters Branches and Services: General Staff, 1915 May-Dec., August 1915, Appendix-1.

143 TNA, W.O. 95/4283, 1 ANZAC, Headquarters Branches and Services: General Staff, 1915 Oct.-Nov., October 1915, Appendix-11

144 TNA, W.O. 95/4283, 1 ANZAC, Headquarters Branches and Services: General Staff, 1915 Oct.-Nov., 28 November 1915.

145 Lokman Erdemir, Çanakkale Savaşı Siyasi, Askeri ve Sosyal Yönleri, İstanbul 2009, s. 241.

146 Jeffery, a.g.e., s.141.
}

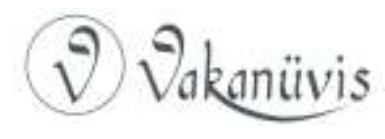


çıkan bilgi ve belgeler ışığında Çanakkale Muharebeleri esnasında böyle bir hadisenin hiçbir zaman yaşanmadığını söylemek gerekir. 124. Alay'dan firar eden İbrahim oğlu Salih ifadesinde; birliğinde savaştan bıkıp kaçmak isteyen çok sayıda asker olduğunu fakat firar tehlikesine karşı subaylar ve astsubayların siperlerde sık sık denetim yaptığından bahsetmektedir. ${ }^{147}$ Diğer yandan 9. Kolordunun 31 Ağustos tarihli bültenine göre, 19. Alaydan esir düşen bir Türk, her gün 50 firarinin kaçmaya çalışırken Bolayır hattında yakalanıp birliklerine geri gönderildiğini, kendisinin de bunu denediğini fakat başaramadığını belirtmiştir. Türk askerinin bu ifadesinin yanına parantez içinde "Yakalandıktan sonra vurulmadığına göre Türkler asker sıkıntısı çekiyor olmalı" ifadesi not olarak düşülmüştür. ${ }^{148}$ Fakat daha önce de belirtildiği gibi, Çanakkale Muharebelerinde dikkat çekecek kadar büyük miktarda bir firar hadisesi yaşanmadığını belirtmek gerekir.

Bilindiği gibi Müslüman olmayan azınlık askerlerine çok güvenilmediğinden bunların karşı tarafa kaçmalarını önlemek için çeşitli tedbirler alınmış ve bu askerlerden daha çok geri hizmette faydalanılmıştır. Firar eden askerlerin daha çok Türk olmayan, ErmeniRum azınlıktan olduğu düşünülse de raporlara baktığımızda karşı tarafa firar eden Türk askerlerinin sayısının fazla olduğu görülmektedir. Kaçaklarla ilgili incelenen belgeler arasında en dikkat çekeni, o dönem Arıburnu bölgesinde bulunan 5. Tümen'den Binbaşı Hacı Ali Bey adında bir subaydır. 8 Mayıs 1915 tarihli istihbarat raporunda bu subayın firar ettikten sonra Türk birlikleri ile ilgili verdiği bilgiler raporlanmıştır. ${ }^{149}$

Kaçak subaylar arasında Arap subayların da sayısının az olmadığını belirtmek gerekir. 12. Tümen 34. Alay'dan Şerif el Faruki isminde bir Arap Üsteğmen, Anafartalar'da İngilizlere firar ettikten sonra bütün Anafartalar bölgesindeki Türk birlikleri, bu birliklerin başındaki Türk komutanlarının isimleri, savunma pozisyonları ve hatta topçu birlikleri ve top mevzilerine kadar son derece ayrıntılı ve işe yarar bilgiler

147 TNA, W.O. 95/4313, 42 DIVISION, Headquarters Branches and Services: General Staff, 1915 May-Dec., December 1915, Appendix-1.

148 TNA, W.O. 95/4276, 9 CORPS, Headquarters Branches and Services: General Staff, 1915 June-Sept., 31 August 1915.

149 TNA, W.O. 157/648, General Headquarters: Intelligence Summaries, General Staff 1915 Aug., 8 August 1915.

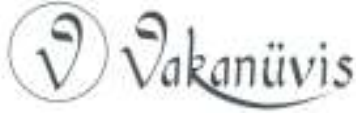


vermiştir. Sadece Çanakkale'deki birliklerin değil, Türk ordusunun kritik görevlerinde bulunan 11 Türk kurmay subayın isimlerini de vermiştir. Bu Arap subayın ifadesinde en çok göze çarpan bilgi ise Türk ordusu içinde gizli bir Arap organizasyonunun varlığından bahsetmesidir. ${ }^{150}$ Verdiği bilgilere göre örgütün lideri Aziz Mısri'dir. Üsteğmen Faruki örgütün amacının İngilizlere firar ettikten sonra Şam'a dönmek ve burada Türklere karşı devrim başlatmak olduğunu belirtir. Kendisi de peygamber soyundan geldiğini iddia ederek Mekke'ye geçmek istediğini söyler. ${ }^{151}$

\section{Sonuç}

Çanakkale Muharebeleri'nin İngilizler adına başarısızlıkla sonuçlanmasının ardından Başkomutan lan Hamilton ciddi şekilde eleştirilmiştir. Savaş Bakanlığının gerekli tüm hazırlıkları yapmadan Gelibolu'daki çıkarmalara başladığı konuşulmuştur. Gelibolu coğrafyasının yeterli derecede bilinmediği, çıkarma koyları ve arkasında uzanan arazideki zorlukların analiz edilmediği, hazırlanan haritaların son derece yetersiz olduğu gibi olumsuzluklar sıklıkla tarihçiler tarafından dile getirilmiştir. Hamilton da savaştan sonra ellerinde bölge hakkında yeterince bilgi olmadığını, haritaların ise yetersiz olduğunu belirtmiştir. Hamilton'ın söylemleri tam olarak doğruyu yansıtmamaktadır. Belki de savaşı kaybetmenin vermiş olduğu ruh hali içinde kendi başarısızlığının üstünü örtme ve çeşitli bahaneler üretme çabası içine girdiği düşünülebilir. Zira her ne kadar Hamilton'ın önünde çıkarmalara hazırlanmak için çok kısa bir süre olsa da, bu kısa sürede karargâhına azımsanmayacak derecede istihbarat bilgi akışı sağlanmıştır. Çıkarmalar yapıldıktan sonra da istihbarat akışı her aşamada devam etmiştir. Muharebeler başlamadan önce çok sayıda harita hazırlanmış ve bu haritalar stratejik, coğrafi ve taktik bilgilerle desteklenmiştir. 25 Nisan'da ordu başarılı bir şekilde karaya çıkıp Alçıtepe ve Kilitbahir Platosu'nu ele geçirdikten sonra Boğaz'a inip yolu

\footnotetext{
150 Firari Arap Üsteğmenin bahsettiği bu gizli örgütün adı “Fetat el-Arap” idi. İngilizlerle temasta olan örgütün asıl amacı, Osmanlı Devleti'ne isyan ederek Halifeliğin tekrar Araplara geçmesini sağlamak ve bağımsız bir Arap devleti kurmaktı. Konu hakkında ayrıntılı bilgi için bknz: İsmail Köse, Arap İsyanı, İstanbul 2018.

151 TNA, W.O. 157/648, General Headquarters: Intelligence Summaries, General Staff 1915 Aug., 21 August 1915.
}

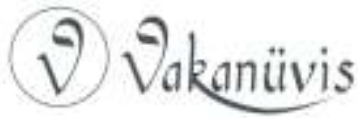


donanmaya açabilse muhtemelen bu harita ve yetersiz istihbarat konusunun hiçbir zaman gündeme gelmeyeceği çok açıktır.

Daha önce de belirtildiği gibi İngilizler on dokuzuncu yüzyılın başından beri, dünyanın en stratejik noktalarından biri olan Çanakkale Boğazı hakkında önemli çalışmalar yapmış ve stratejik bilgiler edinmişlerdir. 1799,1854 ve hatta 1876 'da da İngiliz askeri heyetleri bölgedeydi. 1909-1914'e kadar Osmanlı Bahriyesinde görev yapan Amiral Limpus delegasyonu da kritik bilgilere sahipti. Dolayısıyla Gelibolu Yarımadası ve Çanakkale Boğazı bölgesinin başlıca coğrafi özelliklerinin ve savunma mekanizmalarının İngilizler tarafından bilinmediği, 1915 çıkarmalarından önce ellerinde yanlış haritalar olduğu bilgisi gerçeklerle örtüşmemektedir.

İstihbarat faaliyetleri başladıktan sonra haber alma merkezinin tek bir bölgeye odaklanmadığı ve İstanbul'dan Suriye'ye, Mezopotamya'dan Anadolu'nun çeşitli şehirlerine kadar pek çok yerden bilgi akışı sağlandığı görülmektedir. Uzun yıllardır Osmanlı coğrafyasını iyi bilen ve buralarda aktif olan İngilizlerin istihbarat toplamak için casus bulmakta zorlandıkları söylenemez. Zira savaşın başından beri İstanbul, Çanakkale, Ege Adaları ve İzmir gibi bölgelerde yaşayan azınlık unsurları İngilizler ile işbirliği içerisindeydi. Raporların içeriğine baktığımızda, bilgi kaynağı olarak, ya daha önce bu bölgelerde yaşayan gayrimüslim azınlıkların ya da Avrupalı gezginlerin kullanıldığı açıktır. Diğer yandan Mezopotamya, Suriye ve Filistin gibi bölgelerde de Araplar İngilizlere son derece önemli bilgiler aktarmışlardır. Çalışmanın içinde belgeleriyle belirtildiği gibi, Türk ajanlardan alınan bilgiler de azımsanmayacak derecededir. İngilizler Türk subaylarından bile bilgi almışlardır. İngilizler I. Dünya Savaşının ilerleyen yıllarında Türkler ve Türk ordusu hakkında istihbarat toplamaya devam etmişlerdir. Hatta Milli Mücadele yıllarında mücadelenin kalbi Ankara'dan dahi casusları vasıtasıyla tutarlı istihbarat bilgi akışı sağlamışlardır.

Osmanlı Devleti, İngilizlerin istihbarat faaliyetlerine karşı koymak için çeşitli önlemler alsa da bilgi akışını tamamen engelleyememiştir. Özellikle İstanbul kaynaklı istihbarat bilgileri savaş boyunca kesintisiz şekilde aktarılmıştır. Askeri istihbarat bültenlerinde, İstanbul'daki halkın gündelik yaşamı, yaşanan askeri hareketlilik ve buraya

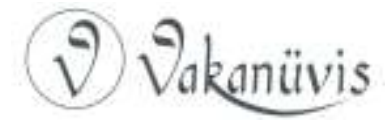


gönderilen yaralıların sayısı hakkında her aşamada çok ayrıntılı bilgiler yer almıştır. Diğer taraftan İngilizler, nasıl Çanakkale bölgesinde yaşamış Rumlardan veya Suriye ile Irak'taki Araplardan istihbarat bilgileri topluyorsa, Türkler de Ege'deki adalarda yaşayan yerel halktan ve Mısır'da olan casuslarından düzenli olarak istihbarat bilgisi temin ediyordu. İngilizlerin Mısır'dan Çanakkale önlerine kadar olan bütün hareketleri takip ediliyordu.

Çanakkale'de muharebeler başladıktan sonra ise istihbarat bültenleri daha çok hava, deniz ve karadan yapılan gözlem ve keşiflere göre hazırlanmıştır. Bu keşif çalışmalarında daha çok Türk hatlarının ve top mevzilerinin yerleri ile Gelibolu'ya hangi miktarda Türk birliğinin getirildiği tespit edilmeye çalışılmıştır. Her birlik, kendi karşısındaki Türk birliğinin hareketlerini gözleyip günlük olarak raporlar hazırlamakla sorumludur. Yapılan istihbarat çalışmaları neticesinde Türk siperlerinin son derece ayrıntılı krokileri çizilerek bunlar birliklere belli aralıklarla dağıtılmıştır.

Esir ve kaçakların ifadeleri ise istihbarat bültenlerinde önemli bir yer tutmaktaydı. Bu sayede her aşamada Türk ordusunun moral vaziyetiyle ilgili analizler yapılıyor, Türklerin hangi şartlarda savaştığı ve teçhizatları hakkında bilgi toplanıyordu. Yine Gelibolu'da hangi Türk birliklerinin bulunduğu ve bu birliklerin organizasyonu ile ilgili temel bilgiler esir ifadeleri sayesinde öğrenilmekteydi.

Bütün bu istihbarat çalışmalarına rağmen İngilizlerin neden başarılı olamadığı sorusu akıllara gelebilir. Unutulmamalıdır ki bir muharebede başarı sadece gerçeğe en yakın istihbarat bilgilerini toplamakla gelmez. Başarı, toplanılan istihbaratın doğru şekilde analiz edilmesinin yanında iyi bir planlama ve doğru strateji arasındaki etkileşime bağlıdır. Tekrar etmek gerekirse Hamilton'ın kendi belirttiği gibi, elinde çıkarma yapılacak bölgeler hakkında haritalar olmadığı, yeterli istihbarat sağlanmadığı ve bunun sonucu iyi planlama yapılamadığı hakkında var olan genel kanı gerçeği yansıtmamaktadır. İstihbarat raporlarında görülmektedir ki, hem taktik, hem coğrafi konular hakkında isabetli raporlar hazırlanmıştır. 25 Nisan çıkarmalarından önce Türk ordusunun ağırııla Bolayır'a kaydırıldığı, yarımadanın güneyindeki sahillerin zayıf kuvvetlerle tutulduğu, 6 Ağustos Anafartalar (Suvla) çıkarmasında ise çok az sayıda Türkün bölgede olduğu ve Türklerin çıkarmayı yine

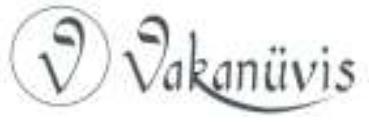


Bolayır tarafından beklediği son derece isabetli bir şekilde tespit edilmiş ${ }^{152}$ ve bu bilgiler çıkarmalar başlamadan önce genel karargâha rapor edilmiştir. Çıkarmalar başladıktan sonra buralarda istihbarat raporlarının aksini gösteren, Hamilton'ın planlarını suya düşürecek sürprizler ile karşılaşılmamıştır. İngilizler adına harekâtın başarısız geçmesinin sebebi çıkarmaların başlangıcından itibaren, her aşamada yapılan taktik yanlışlar ve organizasyon bozukluklarıdır dersek yanılmış olmayız. Hamilton'ın kendi başarısızığını örtmek için çeşitli bahanelerin arkasına sığındığı çok açıktır. Diğer yandan Türk komuta kademesi de muharebeler boyunca çok ciddi stratejik hatalar yapmış, fakat İngilizler bu hataları değerlendirememiştir.

1914 sonundan itibaren Çanakkale Boğaz'ı önünde başlayan askeri hareketlilik Türklerin dikkatini çekmiş ve İngilizler Gelibolu'ya sürpriz bir çıkarma yapma şansını daha en başta kaçırmışlardır. Bütün dünyanın gözü Çanakkale'ye çevrilmişken ve neredeyse Türklerin gözü önünde haftalarca süren çıkarma hazırlıklarına girişilmişken başarı şansı daha da düşürülmüştür. Hamilton, her şeye rağmen, 25 Nisan'da ve 6 Ağustos'ta Türklere karşı taktik üstünlüğü (Türk savunma stratejisinin yanlışlığından dolayı) ele geçirmiş ama daha ilk andan itibaren yaşanan organizasyon bozuklukları ve emir komutada yaşanan kargaşa İtilaf Devletlerinin savaşı kaybetmesine yol açmıştır. Başta Mustafa Kemal olmak üzere Türk komutan ve askerlerinin kararlı direnişi de İngilizleri durduran en önemli unsurlardan biridir.

Bu noktada, özellikle Mustafa Kemal'in Çanakkale Muharebeleri'ne olan etkisi üzerinde önemle durulması gerekmektedir. Muharebelerin gidişatını tam üç kez son derece kritik şekilde değiştiren Mustafa Kemal Bey, 25 Nisan günü Arıburnu'na çıkan Anzak kuvvetlerine, ihtiyat tümeninin komutanı olmasına rağmen, üstlerinden emir almadan tamamen kendi inisiyatifiyle tam zamanında müdahale etmiş ve daha ilk gün cephenin çökmesini engellemiştir. Ağustos ayına gelindiğinde ise sorumluluktan kaçmayarak Conkbayırı ve Anafartalar'daki bütün kuvvetlerin emrine verilmesi gerektiğini belirtmiş ve Anafartalar Grup Kumandanı olduktan sonra, Anafartalar'a çıkan İngiliz Kolordusunu 9 Ağustos'ta kesin olarak mağlup etmiştir. 10

152 İngiliz istihbaratı Anafartalar'daki Türk gücünü 4.000 kişi olarak hesaplamıştır. Presland, a.g.e, s.205. Gerçekte ise bölgede 3.000 Türk askeri mevcuttu.

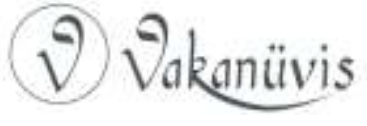


Ağustos tarihinde ise bütün bölgenin kilidi olan Conkbayırı'nın bir bölümünü ele geçiren düşman kuvvetlerini bizzat yönettiği süngü taarruzu ile tepeden atmayı başarmıştır. Özellikle 10 Ağustos Conkbayırı Taarruzu Çanakkale Muharebeleri içinde bir doruk noktasıdır. Mustafa Kemal'in taktik dehasının en önemli örneklerinden biridir. Her iki orduda da Mustafa Kemal kadar muharebelerin gidişatına etki eden başka bir komutan olmamıştır.

\section{Kaynakça}

\section{Arşiv Kaynakları}

\section{The National Archives}

W.O. 157/647, General Headquarters: Intelligence Summaries, General Staff 1915 Mar. 6-July 31, 21 March 1915.

W.O. 157/648, General Headquarters: Intelligence Summaries, General Staff 1915 Aug., 8 August 1915, 21 August 1915.

W.O. 157/648, General Headquarters: Intelligence Summaries, General Staff 1915 Aug., Appendix 6.

W.O. 157/668, Anzac Corps: Intelligence Summaries, April 1915.

W.0.157/678, New Zealand and Australia Division: Intelligence Summaries, April 1915.

W.O. 301/499, Gallipoli Peninsula: Sketch plan showing results of Air Reconnaissance to 14 Apr 1915.

W.O. 301/500, Gallipoli Peninsula: Sketch plan showing results of Air Reconnaissance to $18 \mathrm{Apr} 1915$.

W.O. 95/4263, General Headquarters: Branches and Services, General Staff 1915 Feb. - Apr., March 1915, Appendix-10.

W.O. 95/4276, 9 CORPS, Headquarters Branches and Services: General Staff, 1915 June - Sept., 2 August 1915, 31 August 1915.

W.O. 95/4276, 9 CORPS, Headquarters Branches and Services: General Staff, 1915 June - Sept., 9 July 1915, 20 July 1915, 24 July 1915, 29 July 1915.

W.O. 95/4276, 9 CORPS, Headquarters Branches and Services: General Staff, 1915 June - Sept., 1 September 1915, 4 September 1915.

W.O. 95/4277, 9 CORPS, Headquarters Branches and Services: General Staff, 1915 Oct. - Nov. 8 October 1915, 15 October 1915.

W.O. 95/4278, 9 CORPS, Headquarters Branches and Services: General Staff, 1915 Dec., 5 December 1915, 8 December 1915.

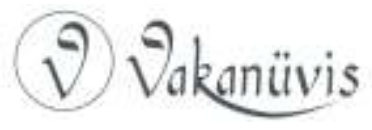


W.O. 95/4280, 1 ANZAC, Headquarters Branches and Services: General Staff 1915 Feb.-May., May 1915, Appendix-36-37.

W.O. 95/4280, 1 ANZAC, Headquarters Branches and Services: General Staff 1915 Feb.-May., 14 April 1915.

W.O. 95/4283, 1 ANZAC, Headquarters Branches and Services: General Staff, 1915 Oct.-Nov., 1 October 1915, 6 October 1915, 12 October 1915, 20 October 1915.

W.O. 95/4283, 1 ANZAC, Headquarters Branches and Services: General Staff, 1915 Oct.-Nov., October 1915, Appendix-11.

W.O. 95/4283, 1 ANZAC, Headquarters Branches and Services: General Staff, 1915 Oct.-Nov., 28 November 1915.

W.O. 95/4304, 29 DIVISION, Headquarters Branches and Services: General Staff, 1915 Jan. - June, 14 April 1915.

W.O. 95/4304, 29 DIVISION, Headquarters Branches and Services: General Staff, 1915 Jan.-June, April 1915, Appendix-1, 2, 4, 5, 6, 7, 8, 9.

W.O. 95/4304, 29 DIVISION, Headquarters Branches and Services: General Staff, 1915 Jan.-June, May 1915, Appendix-14, 15, 23, 30, 32, 34.

W.O. 95/4304, 29 DIVISION, Headquarters Branches and Services: General Staff, 1915 Jan.-June, 16 May 1915, No:4.

W.O. 95/4304, 29 DIVISION, Headquarters Branches and Services: General Staff, 1915 Jan.-June, 17 May 1915, No:5

W.O. 95/4304, 29 DIVISION, Headquarters Branches and Services: General Staff, 1915 Jan.-June, 19 May 1915, 19 May 1915, No:7, 22 May 1915, No:10, 23 May 1915, 25 May 1915, 26 May 1915, 28 May 1915, 29 May 1915.

W.O. 95/4304, 29 DIVISION, Headquarters Branches and Services: General Staff, 1915 Jan.-June, 1 June 1915.

W.O. 95/4304, 29 DIVISION, Headquarters Branches and Services: General Staff, 1915 Jan.-June, Miscellaneous Intelligence Bulletin, Appendix-1, 34.

W.O. 95/4305, 29 DIVISION, Headquarters Branches and Services: General Staff, 1915 July-1916 Feb., February 1915, Appendix-2, 3, 4, 6, 7.

W.O. 95/4305, 29 DIVISION, Headquarters Branches and Services: General Staff, 1915 July-1916 Feb., 6 October 1915, 12 October 1915, 15 October 1915, 23 October 1915,

W.O. 95/4305, 29 DIVISION, Headquarters Branches and Services: General Staff, 1915 July-1916 Feb., October 1915, Appendix-14.

W.O. 95/4313, 42 DIVISION, Headquarters Branches and Services: General Staff, 1915 May-Dec., August 1915, Appendix-1.

W.O. 95/4313, 42 DIVISION, Headquarters Branches and Services: General Staff, 1915 May-Dec., 28 September 1915.

W.O. 95/4313, 42 DIVISION, Headquarters Branches and Services: General Staff, 1915 May-Dec., December 1915, Appendix-1.

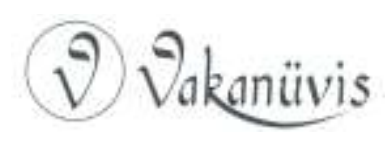




\section{Kitap ve Makaleler}

ALBAYRAK, Muzaffer -Vahdettin Engin, Kut'ül Amare Zaferi 1916, İstanbul 2017.

AŞAR, Servet, "Çanakkale Savaşında İstihbarat ve Propaganda", http://canakkalesavaslari.comu.edu.tr/viewer, Son Erişim Tarihi: 01.12.2019.

ATABEY, Figen, Çanakkale Muharebelerinin Deniz Cephesi, Ankara 2014.

Birinci Dünya Savaşı'nda Çanakkale Cephesi, C.V, Kitap I-II-III, Ankara 2012.

BÜYÜKTUĞRUL, Afif, Osmanlı Deniz Harp Tarihi, C.III, İstanbul 1983.

CALLWELL, Charles Edward, Experiences of a Dug-Out 1914-1918, London 1920.

CHASSEAUD, Peter-DOYLE, Peter, Grasping Gallipoli, Terrain, Maps and Failure at the Dardanelles 1915, England 2005.

DOLAN, Hugh, Gallipoli Air War, Sydney 2013.

ELDEM, Vedat, Harp ve Mütareke Yıllarında Osmanlı Imparatorluğunun Ekonomisi, Ankara,1994.

ERDEMiR, Lokman, I. Dünya Harbi'nin Istanbul'da Sosyal Hayata Etkisi, Birinci Dünya Savaşı'nda Osmanlı Devleti, İstanbul 2015.

ERDEMIR, Lokman, Çanakkale Savaşı Siyasi, Askeri ve Sosyal Yönleri, İstanbul 2009.

GÖZCÜ, Alev, “I. Dünya Savaşı ve Osmanlı Devleti'nin Gündelik Hayatından Kesitler", Çağdaş Türkiye Tarihi Araştırmaları Dergisi, XVI/32 (2016-Bahar), s.133-169.

HERBERT, Aubrey-Henry Morgenthau, Çanakkale Devler Ülkesinde Devler Savaşı, Çev:Seyfi Say, İstanbul 2007.

JEFFERY, Keith MI6-The History of the Secret Intelligence Service 19091919, England 2010.

KARATAŞER, Büşra, "Birinci Dünya Savaşı ve Mütareke Döneminde İstanbul'un İaşesi", Kahramanmaraş Sütçü Imam Üniversitesi Iktisadi ve Idari Bilimler Fakültesi Dergisi, Haziran 2014, s.97-114.

KIBIL, Mehmet, Çıkarmadan Tahliyeye Arıburnu-Anafartalar Muharebeleri, İstanbul 2017.

KOÇAK, Kamil, "Mısır’ın Fransızlar Tarafından İşgali ve Tahliyesi (17981801)", SAÜ Fen Edebiyat Dergisi, 2008-II, s.141-183.

KON, Kadir, “Almanya'nın İslam Stratejisi Mimarlarından Max Von Oppenheim ve Bu Konudaki Üç Memorandumu", Tarih Dergisi, Sayı 53, (2011/1), s.211-252.

LITTLE, Peter, Men of Gallipoli, England 1988.

MACKENZIE, Compton, Gallipoli Memories, New York 1930.

OGLANDER, Aspinall, Büyük Harbin Tarihi Gelibolu Askeri Harekâtı, C. I-II, Haz.: Metin Martı, İstanbul 2005.

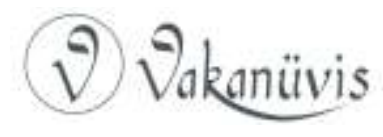


ÖZBAY, Kemal, Türk Asker Hekimliği Tarihi ve Asker Hastaneleri I-II, İstanbul 1976.

PEHLIVANLI, Hamit, "Çanakkale Muharebeleri Sırasında Müttefiklerin Propagandası ve Karşı Propaganda", Atatürk Araştırma Merkezi Dergisi, Cilt: VII / Temmuz 1991 / Sayı: 21, s.535-552.

PRESLAND, John, Deedes Bey-A Study of Sir Wyndham Deedes 1883-1923, London 1942.

ROBERTSON, William, Soldiers and Statesmen 1914-1918, Vol. 1, London 1926.

SANDERS, Liman von, Türkiye'de Beş Yıl, Çev: Eşref Bengi Özbilen, İstanbul 2018.

SARISAMAN, Sadık, I. Dünya Savaşı'nda Türk Cephelerinde Beyannamelerle Psikolojik Harp, Ankara 1999.

SAYILIR, Burhan, Çanakkale Savaşları Sırasında Casusluk Olayları ve Türklerin Casusluk Olaylarına Karşı Aldıkları Tedbirler, Askeri Tarih Araştırmaları Dergisi, Ağustos 2006, Yıl:4, Sayı:8, s.100-108.

SELÇUK, Mustafa, Çanakkale Seferberliği, Savaş, Eğitim, Cephe Gerisi, İstanbul 2016.

SUNATA, İsmail Hakkı, Gelibolu'dan Kafkaslara Birinci Dünya Savaşı Anılarım, Haz.: Kansu Şarman, İstanbul 2003.

STEEL, Nigel-Peter Hart, Gelibolu Yenilginin Destanı, Çev:Mehmet Harmancl, İstanbul 2005.

ŞAHIN, Feyza Kurnaz, "Ingiliz Arşiv Belgelerine Göre I. Dünya Savaşı Yıllarında Afyonkarahisar Üsera Garnizonu'ndaki İngiliz Esirler”, A. Ü. Türkiyat Araştırmaları Enstitüsü Dergisi, Erzurum 2016, s.1255-1307.

ŞAHIN, Feyza Kurnaz, "I. Dünya Savaşı Yıllarında İki Felemenk Temsilcinin Afyonkarahisar Üsera Garnizonu Hakkındaki İzlenimleri: Dirk Johannes Van Bommel ve Dr. Emile Ernest Menten Raporları", Çanakkale Araştırmaları Türk Yıllı̆̆ı, Yıl: 14, Bahar: 2016, Sayı: 20, s.35-63.

TÜRKMEN, Zekeriya, "Psikolojik Harekât Açısından Çanakkale Muharebelerine Dair Bir Değerlendirme", 15.Askeri Tariz Sempozyumu, Ankara 2017, s.325-347.

Türk Silahlı Kuvvetleri Tarihi (1908-1920), Genelkurmay Harp Tarihi Başkanlığı, C.III, Kısım: 6, Kitap: 1, Ankara 1971.

WITMANN, William, Travels in Turkey, Asia-Minor, Syria and Across the Desert into Egypt during the Years 1799, 1800 and 1801, London 1803.

YEŞiL, Fatih, "İstanbul Önlerinde Bir İngiliz Filosu: Uluslararası Bir Krizin Siyasî ve Askerî Anatomisi”, Nizam-ı Kadim'den Nizam-ı Cedide III. Selim ve Dönemi, Ed. Seyfi Kenan, İstanbul 2010.

YILMAZ, Sait, Türk-Ingiliz Istihbarat Savaşları 1914-1918, Ankara 2017. 
Ekler

Ek 1: "Kabatepe ve Seddülbahir Arasındaki Bölgeye Çıkarma Olanakları" Başıkıı 6 Sayfalık İstihbarat Raporunun Ilk Sayfası

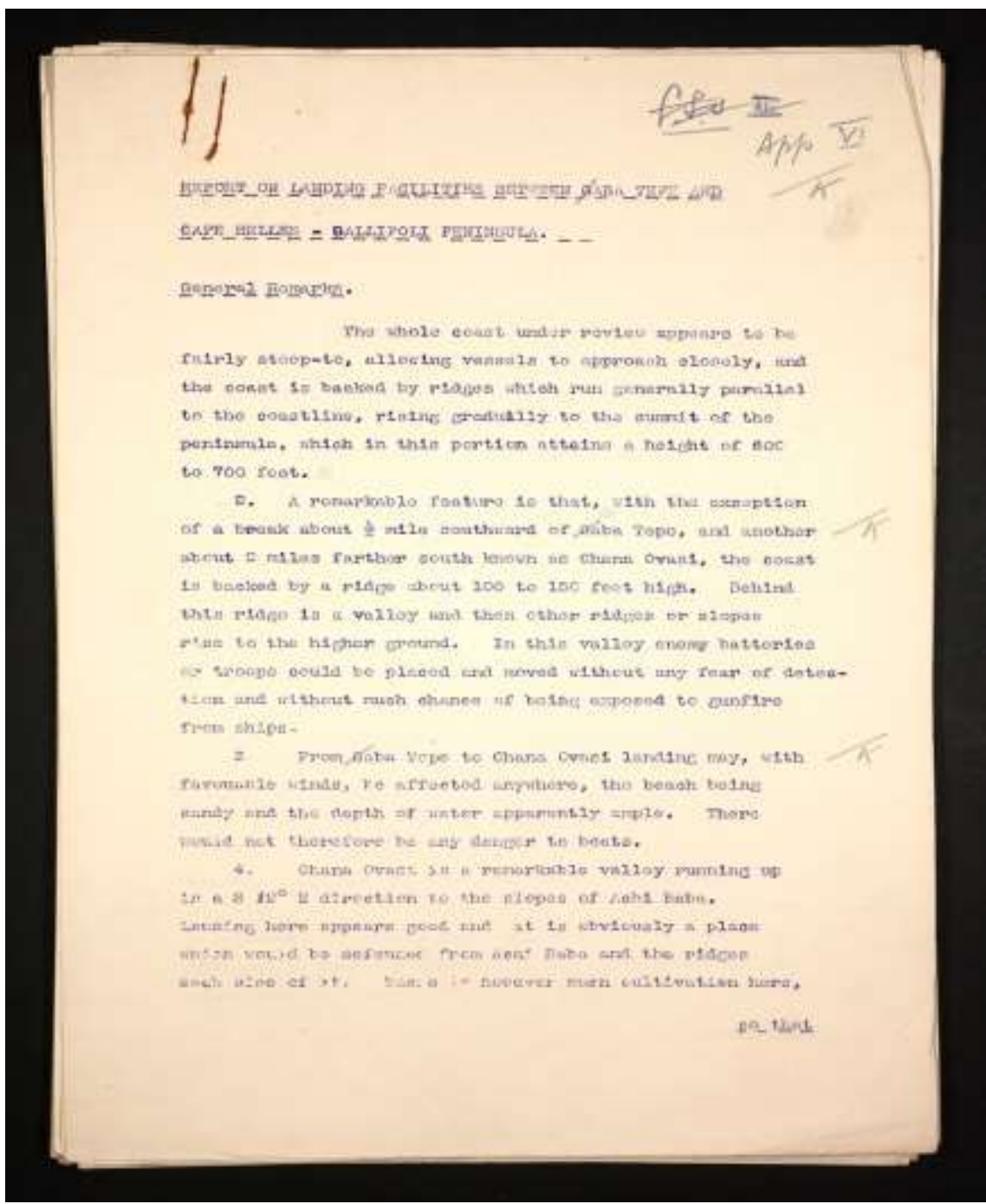

Kaynak: TNA, W.O. 95/4304, April 1915, Appendix-6.

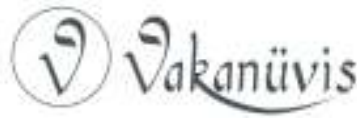


EK 2: Gelibolu Yarımadası'nda Köyler, Yollar ve Su Kaynakları Hakkında Hazırlanan İstihbarat Raporunun Illk Sayfası

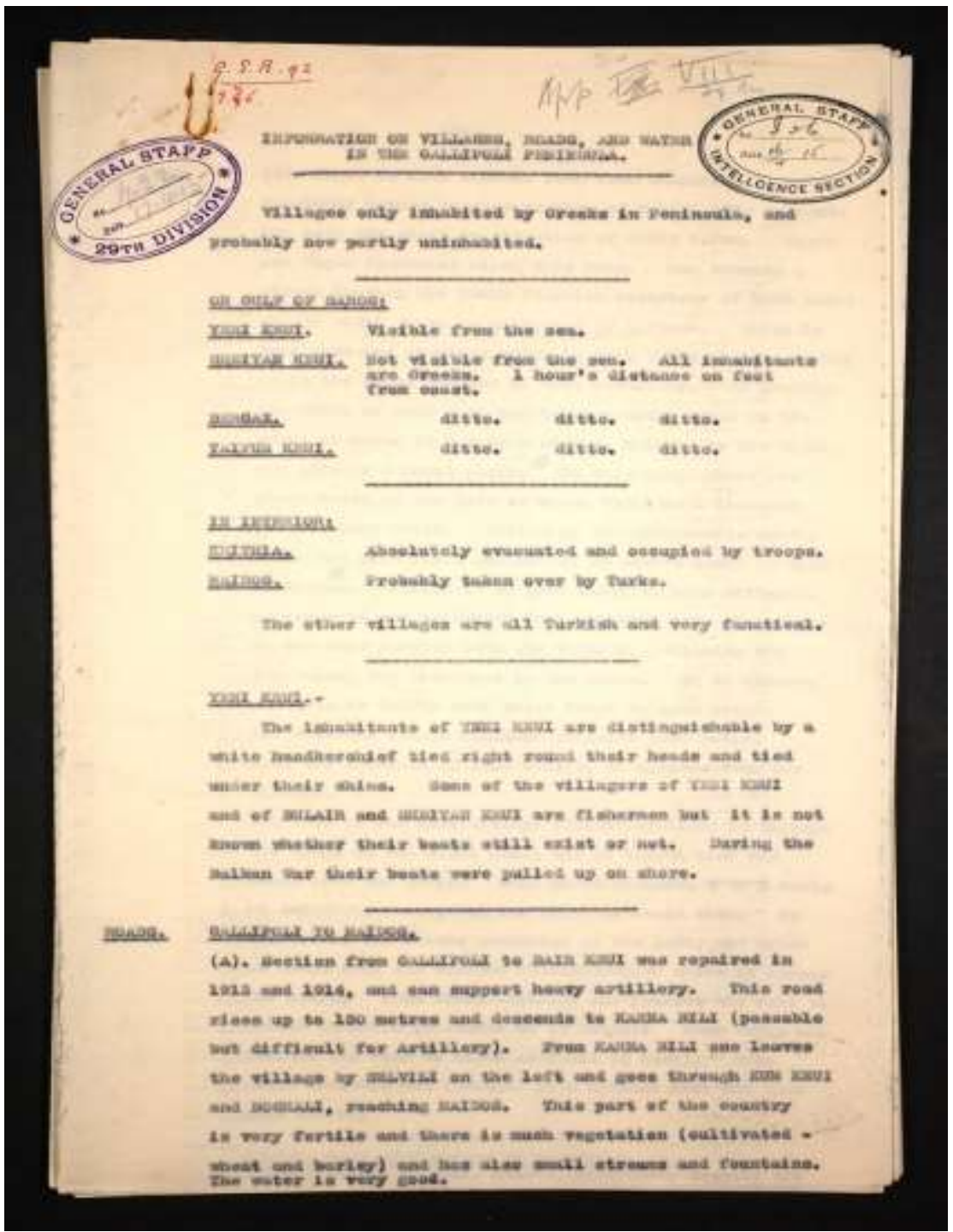

Kaynak: TNA, W.O. 95/4304, April 1915, Appendix-8. 
EK 3: 23 Mayıs 1915 Tarihli Gelibolu'da Esirlerden Alınan Bilgilerle Tespit Edilen Türk Tümen ve Alaylarının Listelendiği İstihbarat Raporu

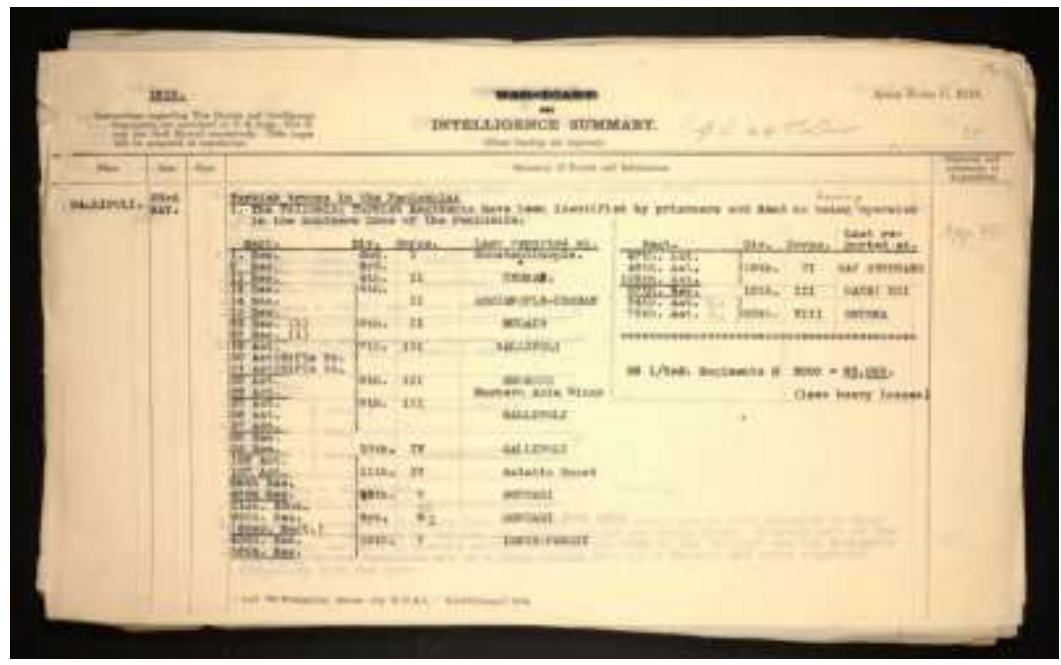

Kaynak: W.O. 95/4304, 23 May 1915.

EK 4: 28 Mayıs 1915 Tarihli Türk Aktif ve Yedek Tümenlerinin Coğrafya Üzerinde Dizilimini Gösteren Harita

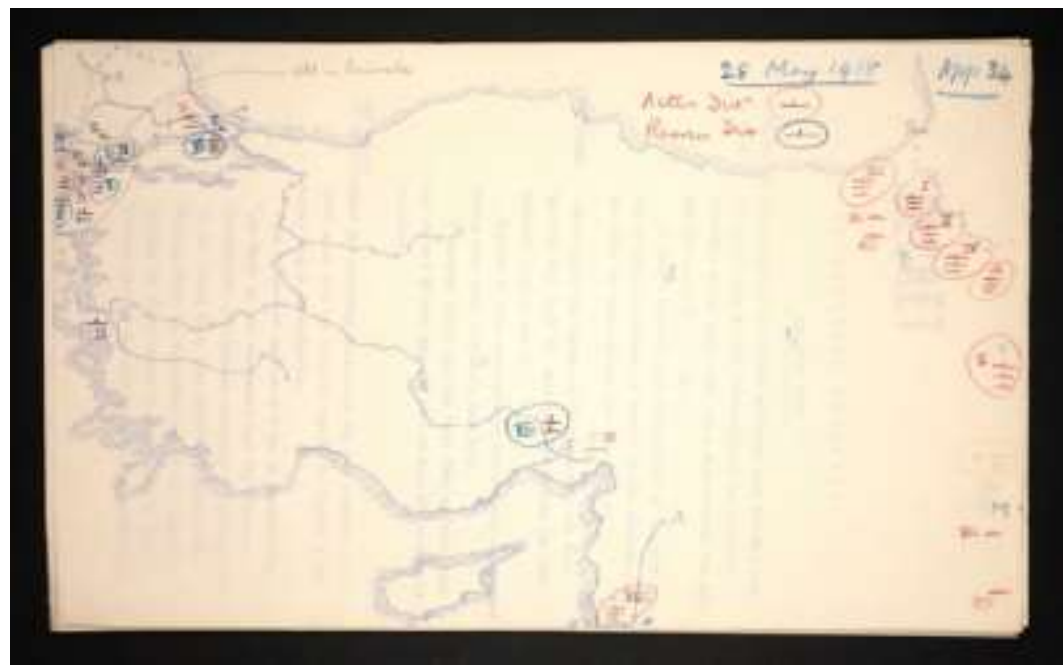

Kaynak: TNA, W.O. 95/4304, Appendix-34.

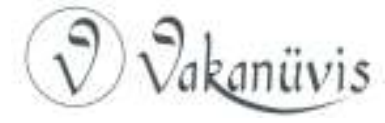


EK 5: Daha Önce Alçıtepe'de Oturan Bir Rum Göçmenin Verdiği Bilgilerin Yanı Sıra, Çeşitli İstihbarat Bilgilerinin Yer Aldığı 29 Mayıs 1915 Tarihli İstihbarat Raporu

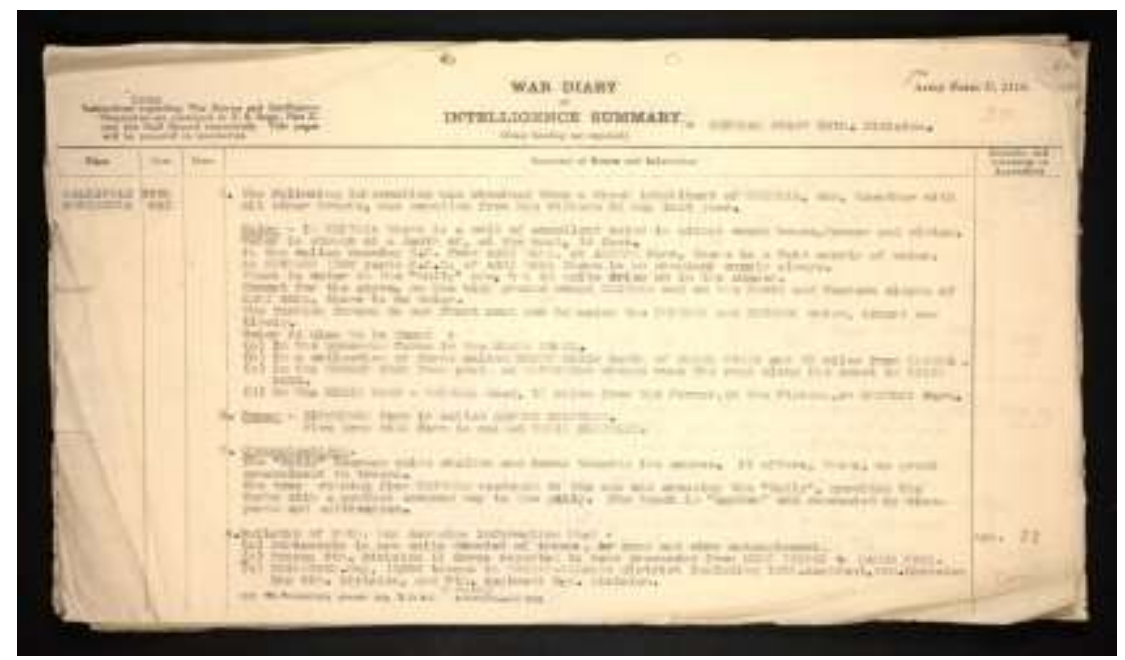

Kaynak: TNA, W.O. 95/4304, 29 May 1915.

EK 6: Yapılan Gözlem-Keşif ve Türk Esir İfadelerine Göre Çizilen Seddülbahir'deki Türk Siperlerinin Bir Kısmının (16 Ekim 1915) Ayrıntılı Krokisi

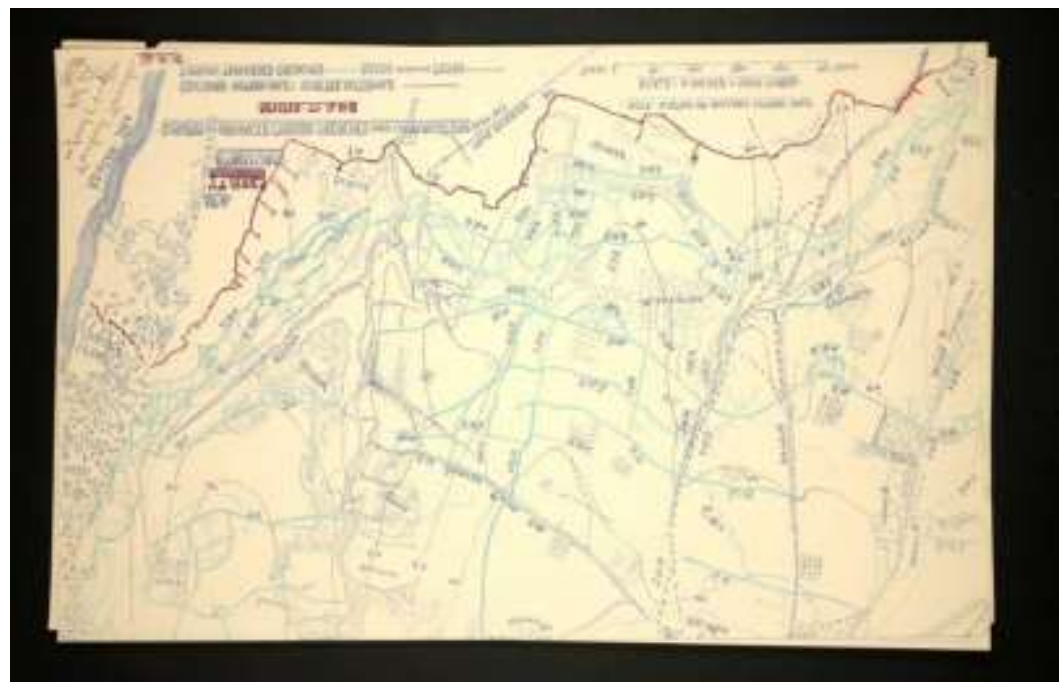

Kaynak: W.O. 95/4313, Appendix-4.

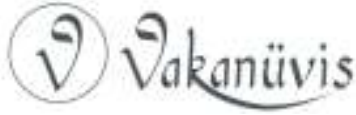


EK 7: İstanbul ve İzmir'de ỉhtiyaç Duyulan Malzemelerin Savaş Devam Ederken Artan Fiyatları (Mayıs 1915)

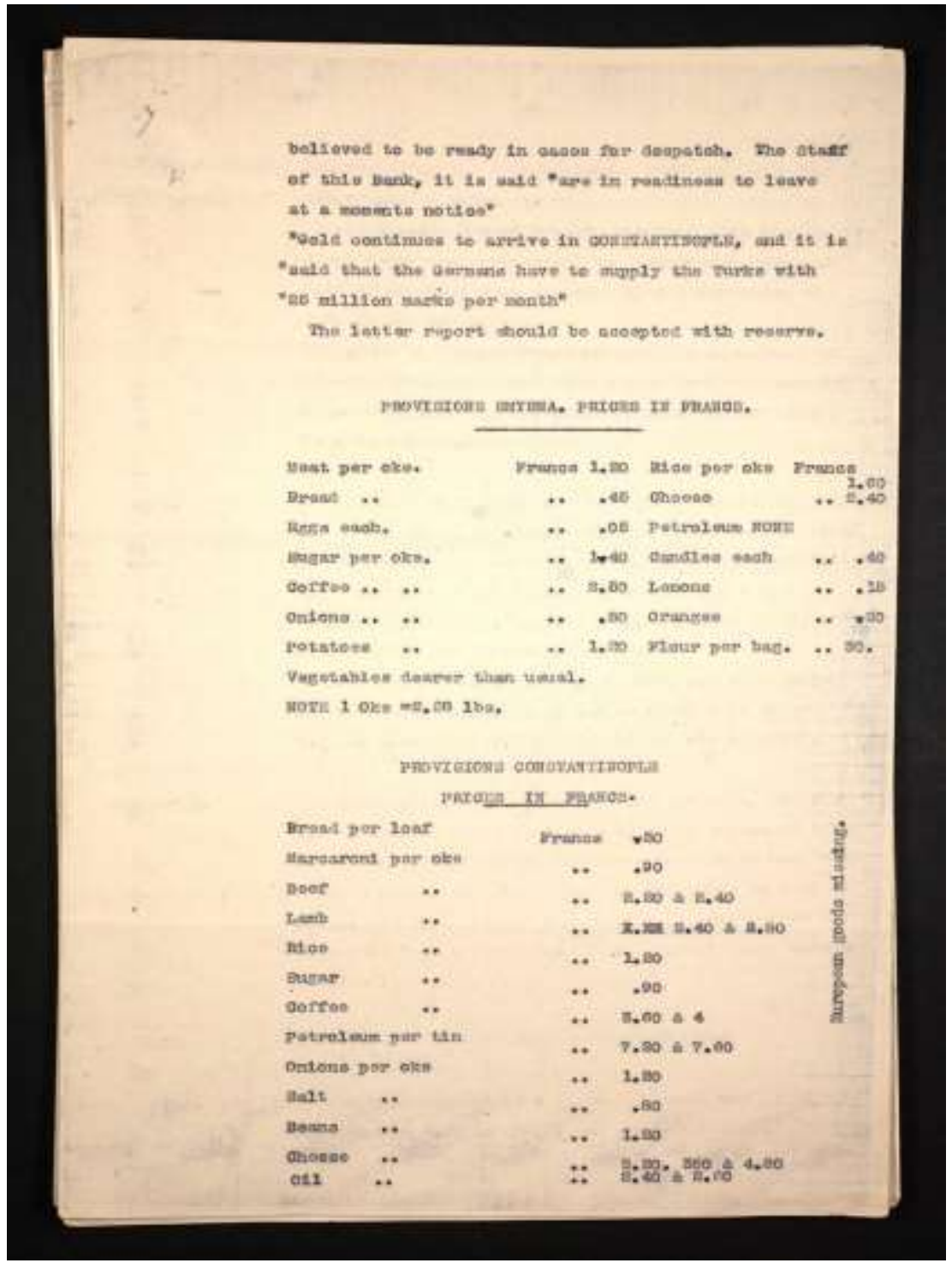

Kaynak: TNA, W.O. 95/4304, May 1915, Appendix-30.

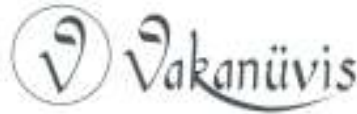


EK 8: 22 Mayıs 1915 Tarihli "Yarımada Gazetesi”

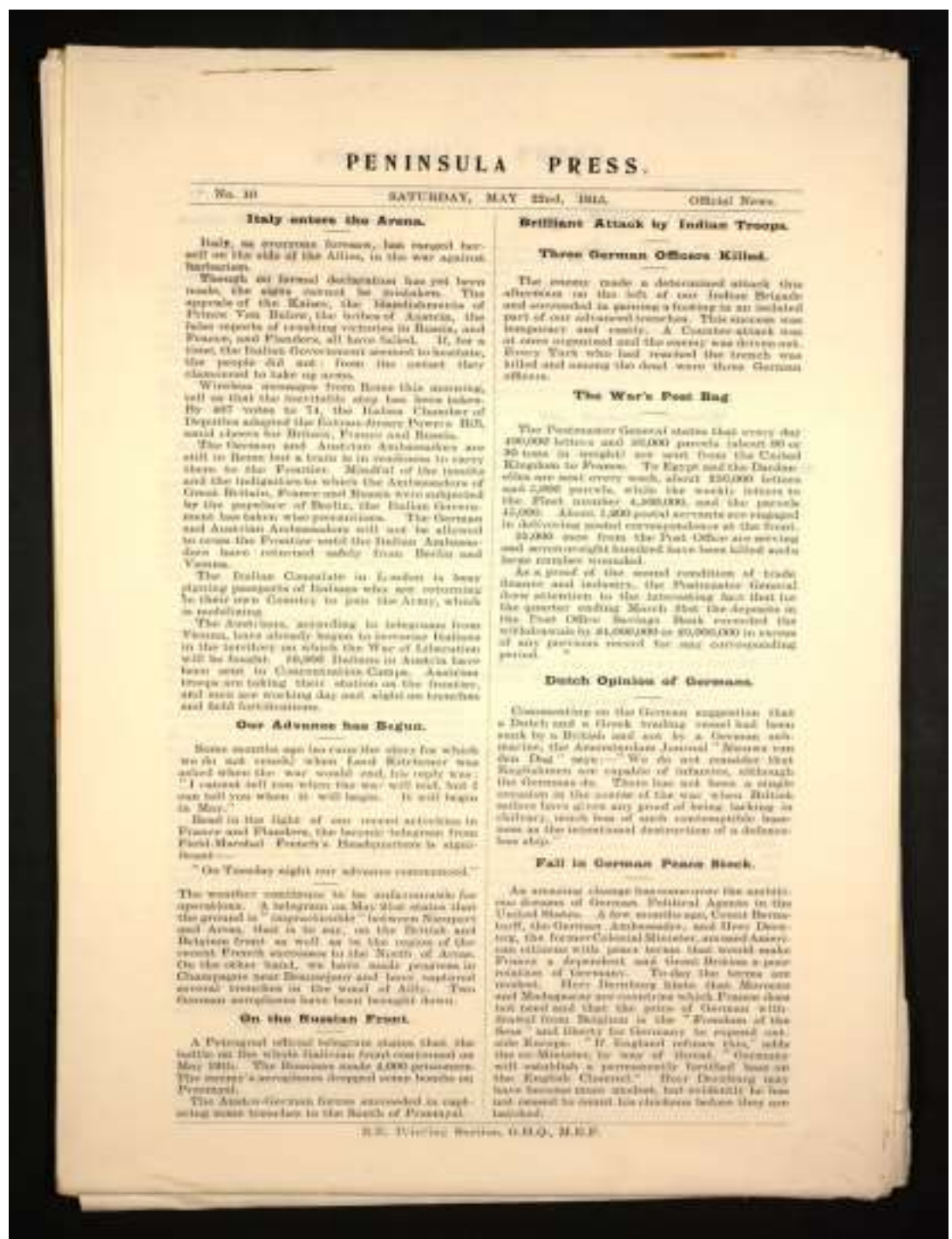

Kaynak: TNA, W.O. 95/4304, 22 May 1915, No:10.

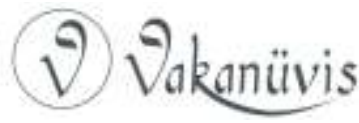


EK-9: Bir Türk Esirin Ağzından Yazılan ve Türk Siperlerine Atılan Propaganda Mektubu

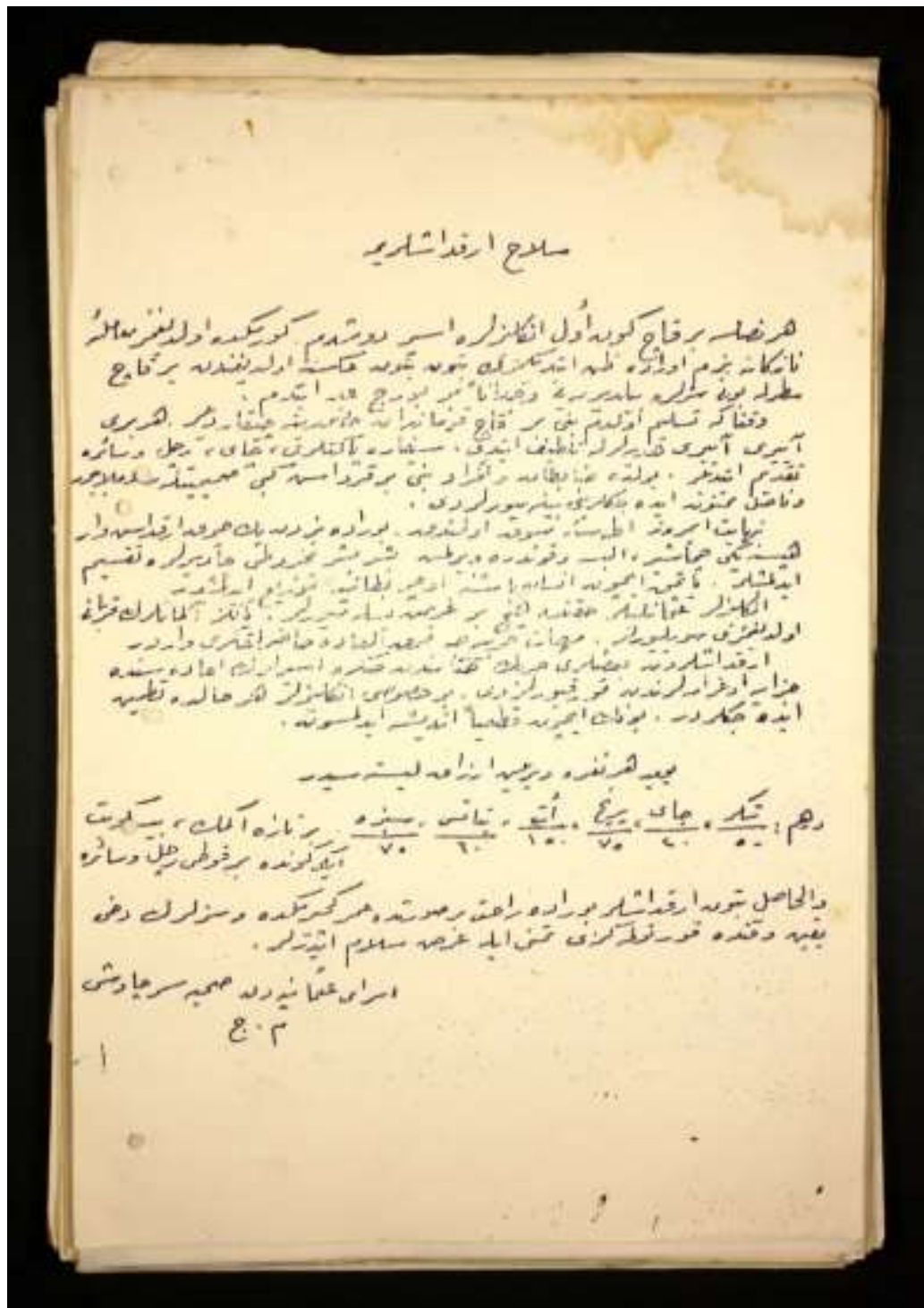

Kaynak: W.O. 95/4276, September 1915.

(V) Vakanüvis 